\title{
DigitalCommons@NYLS
}

Articles \& Chapters

Faculty Scholarship

2018

On Desolation Row: The Blurring of the Borders between Civil and Criminal Mental Disability Law, and What It Means to All of Us

Michael L. Perlin

Deborah Dorfman

Naomi Weinstein

Follow this and additional works at: https://digitalcommons.nyls.edu/fac_articles_chapters

Part of the Disability Law Commons, Law and Psychology Commons, and the Law and Race Commons 


\section{"On Desolation Row": The Blurring of the Borders Between Civil and Criminal Mental Disability Law, and What It Means to All of Us}

Michael L. Perlin, Deborah A. Dorfman, \& Naomi M. Weinstein*

I. INTRODUCTION 60

II. HOW MODERN MENTAL DiSABILITY LAW DEVELOPED. 69

III. AREAS OF "NEGATIVE" BLURRING.................................................

A. Assisted Outpatient Treatment (AOT) Laws......................... 76

B. Sexually Violent Predator Acts (SVPAs)............................... 80

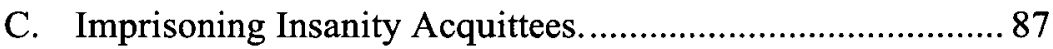

D. Continuity of Care. .......................................................... 90

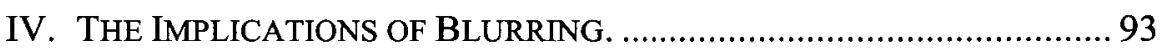

V. AREAS OF "PoSITIVE" BLURRING.................................................. 94

A. Mental Health Courts........................................................... 95

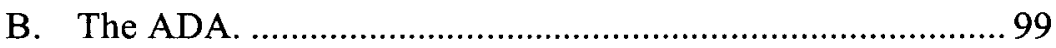

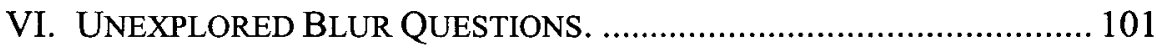

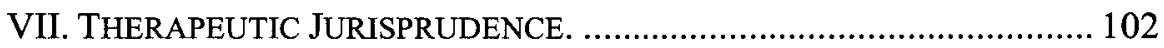

A. TJ and "Negative Blur" Issues............................................. 105

1. TJ and AOT Laws....................................................... 105

2. TJ and SVPAs......................................................... 106

3. TJ and Imprisoning Insanity Acquittees.......................... 109

4. TJ and Continuity of Care.............................................. 111

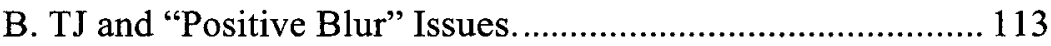

1. TJ and Mental Health Courts......................................... 113

2. TJ and the ADA. .......................................................... 114

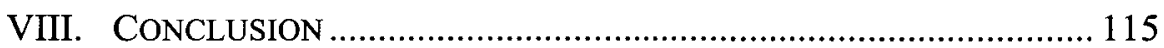




\section{INTRODUCTION}

One of the great tensions of mental disability law is the unresolved, trompe-l'aeil question of whether it is a subset of the civil law or of the criminal law, or something entirely different. ${ }^{1}$ The resolution of this question is not an exercise in formalism or pigeonholing, but is critical to an understanding of the future direction of mental disability law, the deeper meaning of Supreme Court cases ${ }^{2}$ and important state-legislative initiatives, and the whole array of hidden issues and agendas that lurk under the surface of mental disability law decisionmaking.

For decades, mental disability law-even before it was actually called that ${ }^{3}$ - was the law of forensic psychiatry in criminal-trial process settings, comprised mostly of the law of the insanity defense and criminal competencies. ${ }^{4}$ But beginning in the 1970s, American courts began constitutionally limiting the involuntary-civil-commitment power, finding a positive constitutional right to treatment, declaring negative constitutional rights to refuse treatment, and establishing procedural dueprocess rights in all relevant areas of mental disability law--in cases that

\footnotetext{
* Michael L. Perlin, Esq., Professor Emeritus of Law, Founding Director of International Mental Disability Law Reform Project, New York Law School, and Co-founder of Mental Disability Law and Policy Associates; Adjunct Professor, Emory University School of Law; Instructor, Loyola University New Orleans, Department of Criminology and Justice. Deborah A. Dorfman, Esq., Health Law Program Director, Washington Autism Alliance \& Advocacy. Naomi M. Weinstein, Esq., Associate Attorney, Mental Hygiene Legal Service. ${ }^{*}$ The views expressed in this article are of the author and may not be representative of those of Mental Hygiene Legal Service. The authors wish to thank Michael Christensen, Joe Scroppo, Joel Dvoskin, William Richie, Robin Hemenway, Robert Canning, and especially, David Carlson, for their helpful thoughts and suggestions on the issues related to incarceration of insanity acquittees.

${ }^{1}$ See, e.g., Michael L. Perlin, "They Keep It All Hid": The Ghettoization of Mental Disability Law and its Implications for Legal Education, 54 ST. LoUIS U. L.J. 857, 857-59 (2010) [hereinafter Perlin, Ghettoization] (discussing the Supreme Court dealing with mental disability law in a variety of cases and noting the limited coverage in any one legal casebook).

2 See, e.g., Michael L. Perlin, Hidden Agendas and Ripple Effects: Implications of Four Recent Supreme Court Decisions for Forensic Mental Health Professionals, 1 J. FORENSIC PSYCHOL. PRAC. 33 (2001) [hereinafter Perlin, Recent Supreme Court Decisions] (discussing the "ripple effects" of Supreme Court cases on disability law on forensic mental-health and corrections practices).

${ }^{3}$ The actual phrase "mental disability law" did not appear in legal writings until relatively recently. Upon search, the earliest American court case to use the term was published in 1982. See Brewster v. Dukakis, 544 F. Supp. 1069, 1076 (D. Mass. 1982). Its earliest use in a law-review article that is available through the Westlaw database was published in 1986. See James W. Ellis, The Consequences of the Insanity Defense: Proposals to Reform Post-Acquittal Commitment Laws, 35 CATH. U. L. REV. 961, 1012 (1986). The MENTAL DISABILITY LAW REPORTER was first published in 1976. See John W. Parry, Mental and Physical Disability Rights: The Formative Years and Future Prospects, 20 MENTAL \& PHYSICAL DISABILITY L. REP. 627, 627 (1996) (discussing the reporter).

4 Previously, academic focus was on the role of psychiatry in the legal process. See generally, e.g., ANDREW WATSON, PSYCHIATRY FOR LAWYERS (1978). On the significance of this change for the development of this area of the law, see Perlin, Ghettoization, supra note 1, at 863-64.
} 
arose from both criminal and civil settings. ${ }^{5}$

While courts were constitutionally limiting the involuntary civil commitment power, a combination of social, political, and cultural factors-the "public interest law" movement, the "civil rights revolution," what is often called "the Sixties," and candid discussion by other minority and "out-groups" regarding the impact of social oppression and pathology ${ }^{6}$ - began a process of severing the relationship between criminal and civil mental disability law. The insanity defense, for example, which had always been under attack from the political right, ${ }^{7}$ became subject to additional assaults from the civil-libertarian left and the ex-patient "psychiatric survivor" movements. ${ }^{8}$ Much of the important case law that developed during this severing process-establishing, for example, the right to the "least restrictive alternative"-was premised on the fact that the litigant had never been "alleged to have committed any crime." 9

\footnotetext{
5 See infra Part I.

6 See generally Michael L. Perlin \& Heather Ellis Cucolo, Mental Disability Law: CIVIL AND CRIMINAL $\S \S 1-2.1 .1$ to $1-2.2 .6$ (3d ed. 2016) (2018 update) [hereinafter PERLIN \& CUCOLO, CIVIL AND CRIMINAL] (explaining how those factors led to the expansion of rights for persons with mental disabilities); see also Michael L. Perlin, "God Said to Abraham/Kill Me a Son": Why the Insanity Defense and the Incompetency Status Are Compatible with and Required by the Convention on the Rights of Persons with Disabilities and Basic Principles of Therapeutic Jurisprudence, 54 AM. CRIM. L. REV. 477, 478-79 (2017) [hereinafter Perlin, Insanity Defense and Incompetency Status Required by CRPD \& TJ (explaining that various groups involved with the patients' rights revolution were "just fine" with ignoring forensic patients); Michael L. Perlin, "For the Misdemeanor Outlaw": The Impact of the ADA on the Institutionalization of Criminal Defendants with Mental Disabilities, 52 ALA. L. REV. 193, 195 n.17 (2000) [hereinafter Perlin, ADA Impact on Criminal Defendant Institutionalization] (noting that patients' rights bars and mental disability advocates "historically have imposed a strict orthodoxy of analysis geared to separating out 'criminal' mental health law from 'civil' mental health law" and citing Michael L. Perlin, Overview of Rights in the Criminal Process, in 3 Legal Rights of Mentally Disabled Persons 1879, 1891 (Paul R. Friedman ed., 1979) [hereinafter Perlin, Rights of Mentally Disabled in the Criminal Process]).

7 See Michael L. Perlin, Unpacking the Myths: The Symbolism Mythology of Insanity Defense Jurisprudence, 40 CASE W. RES. L. REV. 599, 672 (1989) ("The underpinnings of much of the opposition to the insanity defense, then, should not mask the simple reality that the only significant influence in this country over the past forty years-either rejecting a liberal test or adopting a conservative test-has been from prosecutors, district attorneys and their legislative allies." (emphasis added)).
}

${ }_{8}$ Perlin, Rights of Mentally Disabled in the Criminal Process, supra note 6, at 1891. For the most recent developments, see Perlin, Insanity Defense and Incompetency Status Required by CRPD $\& T J$, supra note 6 , at 497 (critiquing, in particular, arguments by others that assert that the Convention on the Rights of Persons with Disabilities demands the abolition of the insanity defense).

9 See, e.g., Lessard v. Schmidt, 349 F. Supp. 1078, 1096 (E.D. Wis. 1972) ("It seems clear, then, that persons suffering from the condition of being mentally ill, but who are not alleged to have committed any crime, cannot be totally deprived of their liberty if there are less drastic means for achieving the same basic goal."). On how this helped enable a system in which forensic patients are hidden in the system, see Perlin, Insanity Defense and Incompetency Status Required by CRPD \& TJ, supra note 6, at $\mathbf{4 7 8}$ (citing Michael L. Perlin \& Meredith R. Schriver, "You that Hide Behind Walls": The Relationship Between the Convention on the Rights of Persons with Disabilities and the Convention Against Torture and the Treatment of Institutionalized Forensic Patients, in AM. UNIV. CTR. FOR HUMAN RighTS \& HUMANITARIAN LAW, TORTURE AND ILL-TREATMENT IN HEALTHCARE SETTINGS: REFLECTIONS ON THE SPECIAL RAPPORTEUR ON TORTURE'S 2013 THEMATIC REPORT 195 (2013) [hereinafter Perlin \& Schriver, Relationship Between CRPD \& UNCAT]). On why this state of affairs has been "just fine" to all involved in the criminal law and mental-health systems, see Michael L. Perlin, International Human Rights and Institutional Forensic Psychiatry: The Core Issues, in THE USE OF COERCIVE MEASURES IN FORENSIC PSYCHIATRIC CARE: LegaL, ETHICAL AND PRACTICAL CHALleNGES 9, 11 (Birgit Völlm \& Norbert Nedopil eds., 2016) [hereinafter Perlin, International Human Rights and Institutional Forensic Psychiatry], and Perlin \& 
With the conceptualization and legal articulation of the right to refuse treatment ${ }^{10}$ came the most pointed evidence of this budding civ$\mathrm{il} /$ criminal dichotomy. One relatively coherent body of case law regarding this right developed in civil cases; a very different body developed in criminal cases. ${ }^{11}$ In criminal cases on this right, important distinctions were made between cases involving defendants found incompetent to stand trial, currently standing trial, found not guilty by reason of insanity, convicted of a crime, and seeking to avoid execution. ${ }^{12}$ Writing earlier about the right to refuse treatment, in fact, one of the authors had noted the focus of the Supreme Court on "litigational side-effects" of antipsychotic drugs for the defendant, ${ }^{13}$ which in these types of cases perhaps may be of far greater importance to the Court than would alone be the psychological, neurological, or physiological side-effects. Law surrounding the right to refuse treatment is still, in many ways, hopelessly muddled. ${ }^{14}$ But what has been clear is that the rights to refuse treatment in criminal and civil settings are simply different to the courts.

Yet the civil/criminal dichotomy has often seemed blurry when the underlying facts of the cases are carefully examined. The seminal Supreme Court decision on the appropriate burden of proof in involuntary civil commitment cases, Addington $v$. Texas,${ }^{15}$ arose from a case in which the civil patient might have easily been a criminal defendant: he

Schriver, Relationship Between CRPD \& UNCAT, supra note 9, at 197-98.

10 Michael L. Perlin, Decoding Right to Refuse Treatment Law, 16 INT'L J. L. \& PSYCHIATRY 151, 151-53 (1993) [hereinafter Michael L. Perlin, Decoding Right to Refuse Treatment Law].

1t See Michael L. Perlin, "Half-Wracked Prejudice Leaped Forth": Sanism, Pretextuality, and Why and How Mental Disability Law Developed as it Did, 10 J. CONTEMP. LEGAL Issues 3, 30 \& n.158 (1999) [hereinafter Perlin, Sanism \& Pretextuality] (remarking that "[s]anist involuntary civil commitment decisionmaking implicates pretextual right to refuse treatment decisionmaking" and comparing the facts and results of Addington v. Texas, 441 U.S. 418 (1979), which resulted in the defendant alleged of an assault being brought into the mental health system, with Jones $v$. United States, 463 U.S. 354 (1983), which resulted in the defendant alleged of shoplifting being brought into the criminal justice system).

12 See PERLIN \& CUCOLO, CIVIL AND CRIMINAL, supra note 6, §§ 8-7 to 8-7.4, at 8-148 to 8-181 (discussing the development of right to refuse cases).

13 E.g., Michael L. Perlin, "Their Promises of Paradise": Will Olmstead v. L.C. Resuscitate the Constitutional "Lease Restrictive Alternative" Principle in Mental Disability Law?, 37 Hous. L. REV. 999, 1019 (2000) [hereinafter Perlin, Will Olmstead Resuscitate the LRA] (discussing the focus of a concurring justice in Riggins v. Nevada, 504 U.S. 127, 142 (Kennedy, J., concurring in the judgment)); see also Michael L. Perlin \& Meredith R. Schriver, "You Might Have Drugs at Your Command": Reconsidering the Forced Drugging of Incompetent Pre-trial Detainees from the Perspectives of International Human Rights and Income Inequality, 8 ALBANY GOV'T L. REV. 381, 398 (2015) [hereinafter Perlin \& Schriver, Reconsidering Forced Drugging Pre-Trial]; Michael L. Perlin, The Sanist Lives of Jurors in Death Penalty Cases: The Puzzling Role of "Mitigating" Mental Disability Evidence, 8 NOTRE DAME J. L., ETHICS \& PUB. POL'Y 239, 251 (1994); Perlin, Decoding Right to Refuse Treatment Law, supra note 10, at 166.

14 See Michael L. Perlin \& Deborah A. Dorfman, Is it More Than "Dodging Lions and Wastin" Time"? Adequacy of Counsel, Questions of Competence, and the Judicial Process in Individual Right to Refuse Treatment Cases, 2 PSYCHOL. PUB. POL'Y \& L. 114, 123-24 (1996) [hereinafter Perlin \& Dorfman, Individual Right to Refuse Treatment] (noting that Supreme Court cases have led to a "lack of clarity" and "no coherent framework"); infra text accompanying notes $101-03$.

is 441 U.S. 418,433 (1979) (establishing clear and convincing evidence as the appropriate standard). 
had been originally charged with "assault by threat" against his mother. ${ }^{16}$. On the other hand, the leading case on the burden of proof at an retention hearing for an insanity acquittee, Jones $v$. United States, ${ }^{17}$ arose from an incident in which the defendant was initially charged with attempted petty larceny-a failed shoplifting. ${ }^{18}$ Certainly, most of us would see Addington's underlying behavior that precipitated his involvement with the mental disability law system to be more "criminal" than that of Jones. Yet, because of inherently unreviewable street-level police decisions whether to charge criminally or refer for involuntary civil commitment, ${ }^{19}$ Addington became a civil case, and Jones a criminal one, although the offense that underlaid the police apprehension in Addington was a far more serious one than the offense in Jones. ${ }^{20}$

Nonetheless, as mental disability law matured, a dual system appeared to have fallen into place. In civil cases involving civil commitment or decisions regarding institutional rights, a patient was generally entitled to a relatively broad panoply of procedural and substantive dueprocess rights. ${ }^{21}$ On the other hand, the Supreme Court has made it explicit that defendants convicted of crimes would have fewer substantive treatment rights, specifying that at least in the right to refuse treatment, "penological interests" would trump fundamental civil-libertarian interests. ${ }^{22}$ The Court also found that insanity acquittees subject to civil commitment could have fewer due-process rights at retention and review hearings than would other civil patients. ${ }^{23}$

16 Id. at 420.

17463 U.S. 354, 357 (1983) (explaining defendant has the burden to show he is no longer mentally ill or dangerous by a preponderance of the evidence).

$18 \quad I d$ at 359 .

19 See, e.g., STEPHEN A. SAltzBurg \& DANiel J. CAPRA, AMERICAN CRIMINAL Procedure 681 (5th ed. 1996); see also Jon Blue, High Noon Revisited: Commands of Assistance by Peace Officers in The Age of the Fourth Amendment, 101 YALE L.J. 1475, 1488 (1992) (discussing the unreviewability of police decisions). On how persons with mental disabilities are inappropriately and disproportionately arrested on charges of "nuisance" crimes (failing to give a good account of themselves, being disorderly, etc.), see Michael L. Perlin \& Alison J. Lynch, "Had to be Held Down by Big Police": A Therapeutic Jurisprudence Perspective on Interactions Between Police and Persons with Mental Disabilities, 43 FordHAM URB. L.J. 685, 687-88 (2016) Thereinafter Perlin \& Lynch, $T J$ Perspective on Interactions with Police]. While such arrests have major impacts on physical liberty, privacy, and long-term negative effects on life prospects, they also "have major instrumental benefits for police officers and their departments, which they understandably seek to preserve," including economic benefits for police departments. Wayne A. Logan, After the Cheering Stopped: Decriminalization and Legalism's Limits, 24 CORNELL J.L. \& PUB. POL'Y 319, 322, 333-34 (2014).

20 See Perlin, Sanism \& Pretextuality, supra note 11, at $30 \mathrm{n} .158$ (comparing the facts of Addington v. Texas, 441 U.S. 418 (1979) with Jones v. United States, 463 U.S. 354 (1983)).

21 See generally PERLIN \& CUCOLO, CIVIL AND CRIMINAL, supra note 6 , at chs. 7, 9, 13 \& 14 (discussing right to treatment, other institutional rights, criminal incompetencies, and the insanity defense).

22 Washington v. Harper, 494 U.S. 210, 222-223 (1990) (citing Turner v. Safley, 482 U.S. 78,89 (1987) and remarking, regarding whether the "choice to refuse antipsychotic drugs," that "the proper standard for determining the validity of a prison regulation claimed to infringe on an inmate's constitutional rights is to ask whether the regulation is 'reasonably related to legitimate penological interests"); see PERLIN \& CUCOLO, CIVIL AND CRIMINAL, supra note 6, §§ 8-7.1, at 8-155 ("Harper clarifies an important strand of Supreme Court jurisprudence: prison security concerns will, virtually without exception, trump individual autonomy interests.").

23 See Jones v. United States, 463 U.S. 354, 366 (1983) ("It comports with common sense to con- 
As will be discussed further in this article, four subsequent and important developments cast new light on this separation and call into question the future of a dichotomous mental disability law system:

- the proliferation of assisted outpatient treatment (AOT) statutes, ${ }^{24}$ of which New York's Kendra's Law ${ }^{25}$ is perhaps the most well-known example; ${ }^{26}$

- the expansion of sexually violent predator acts (SVPAs), ${ }^{27}$ of which New Jersey's Megan's Law ${ }^{28}$ was the first and is often seen as a model for other states. ${ }^{29}$ SVPAs have been subject to Supreme Court scrutiny elsewhere in cases such as Kansas v. Hendricks, ${ }^{30}$ Seling v. Young, ${ }^{31}$ Kansas v. Crane, ${ }^{32}$ and United States v. Comstock; ${ }^{33}$

- the sanctioning in some jurisdictions of the imprisonment of insanity acquittees in prison facilities; ${ }^{34}$ and

- the provision of no meaningful continuity of care, resulting in large numbers of persons continually "shuttling" between jails (or prisons) and mental hospitals. ${ }^{35}$

clude that someone whose mental illness was sufficient to lead him to commit a criminal act is likely to remain ill and in need of treatment. The precise evidentiary force of the insanity acquittal, of course, may vary from case to case, but the Due Process Clause does not require Congress to make classifications that fit every individual with the same degree of relevance. Because a hearing is provided within 50 days of the commitment, there is assurance that every acquittee has prompt opportunity to obtain release if he has recovere" (internal citations omitted)); Perlin, Sanism \& Pretextuality, supra note 11, at $30 \mathrm{n} .158$ (discussing Jones in this context).

${ }_{24}$ PERLIN \& CuCOLO, CIVIL AND CRIMINAL, supra note 6, $\S \S 4-3.3$ to 4-3.3.1, at 4-176 to 4-194; Michael L. Perlin, Therapeutic Jurisprudence and Outpatient Commitment Law: Kendra's Law as Case Study, 9 PSYCHOL. PUB. POL'Y \& L. 183, 183-84, 194 (2003) [hereinafter Perlin, TJ \& Kendra's Law] (noting the focus on "the implications of assisted outpatient commitment laws (AOPC)" and noting that "[u]nder Kendra's Law, a court may order a person to submit to assisted outpatient treatment if the court finds that the patient" meets certain criteria).

25 N.Y. MENTAL HYG. LAW $\$ 9.60$ (2015).

26 Perlin, $T J \&$ Kendra's Law, supra note 24, at $184 \&$ n. 8 (2003) (noting the "the saturation publicity given to the case").

${ }^{27}$ See generally PERLIN \& CUCOLO, CIVIL AND CRIMINAL, supra note 6, at ch. 5 (providing an overview of "Sex Offender Law"); Michael L. PERLIN \& HeATHER Ellis CuCOlo, SHAMING THE CONSTITUTION: THE DETRIMENTAL RESUlts of SEXUAL VIOLENT PREDATOR LEGISLATION (2017) [hereinafter PERLIN \& CUCOLO, DETRIMENTS OF SVP LEGISLATION] (same).

28 N.J. STAT. ANN $\$ 2$ C: 7-2 (West 1994).

29 See Jonathan Simon, Managing the Monstrous: Sex Offenders and the New Penology, 4 PSYCHOL. PUB. POL'Y \& L. 452, 459-60 (1998) ("New Jersey['s Megan's Law] . . was the first and has received the most administrative and judicial development.").

30521 U.S. 346, 350 (1997).

31531 U.S. $250,253(2001)$.

32534 U.S. 407,409 (2002).

33560 U.S. 126,129 (2010).

34 See, e.g., REV. CODE WASH. $§ 10.77 .091$ (2015) (allowing transfer of unmanageable "criminally insane" patients from state hospital to department of corrections); CAL. WELF. \& INST. CODE $\S 7301$ (2012) (allowing transfer of forensic patients from state hospitals to correctional facilities); see generally Chris Kempner, Unfair Punishment of the Mentally Disabled? The Constitutionality of Treating Extremely Dangerous and Mentally Ill Insanity Acquittees in Prison Facilities, 23 U. HAW. L. REV. 623 (2001).

35 Naomi M. Weinstein \& Michael L. Perlin, "Who's Pretending to Care for Him?" How the Endless Jail-to-Hospital-to-Street-Repeat Cycle Deprives Persons with Mental Disabilities the Right 
These four developments negatively blur the "borderline"36 between civil and criminal mental disability law in very troubling and problematic ways and threaten to make it even more pretextual than it is currently. ${ }^{37}$ Laws such as these enforce social control in punitive ways, often under the guise of the beneficence of civil commitment. The four categories of individuals identified in this article who, based on these developments, straddle the borderline are those subject to AOT laws, those subject to SVPAs, those found not guilty by reason of insanity, and those subject to laws allowing them to be shuttled from hospitals to prisons for minor crimes. Though these categories of individuals appear quite different ${ }^{38}$ there are important and troubling points of commonality when comparing the structures of the underlying laws and policies, as will be discussed below. Moreover, the features of the laws underlying each of these four developments demonstrate apparent comfort with a system in which many functions of civil and criminal mental disability law merge. Remarkably, until now, virtually no other academic attention ${ }^{39}$ has been

to Continuity of Care, 8 WAKE FOREST J.L. \& POL'Y 455, 456-57 \& n.7 (2018) [hereinafter Weinstein \& Perlin, Cycle Deprives Continuity of Care] ("This shuttling or cycling is bad for many reasons, not least of which is the way that it deprives the cohort of individuals at risk from any meaningful continuity of care and how it exacerbates the problems caused by the unnecessary and counterproductive arrests of persons with mental disabilities for 'nuisance' crimes.").

36 For use of the "borderline" metaphor elsewhere in the context of mental disability law, see, for example, Michael L. Perlin, "Where the Winds Hit Heavy on the Borderline": Mental Disability Law, Theory and Practice, "Us" and "Them," 31 LoYOLA L.A. L. REV. 775, 776 (1998) [hereinafter Perlin, Us and Them]; Michael L. Perlin, "The Borderline Which Separated You From Me": The Insanity Defense, the Authoritarian Spirit, the Fear of Faking, and the Culture of Punishment, 82 IOWA L. REV. 1375, 1383 (1997) [hereinafter Perlin, Insanity Defense \& Fear of Faking]; and Perlin, ADA Impact on Criminal Defendant Institutionalization, supra note 6, at 239.

37 Michael L. Perlin, "And My Best Friend, My Doctor/Won't Even Say What It Is I've Got": The Role and Significance of Counsel in Right to Refuse Treatment Cases, 42 SAN DIEGO L. REV. 735, 750-51 (2005) [hereinafter Perlin, Counsel's Role in Right to Refuse Treatment] ("Pretextuality defines the ways in which courts accept (either implicitly or explicitly) testimonial dishonesty and engage similarly in dishonest (and frequently meretricious) decisionmaking, specifically where witnesses, especially expert witnesses, show a high propensity to purposely distort their testimony in order to achieve desired ends. This pretextuality is poisonous; it infects all participants in the judicial system, breeds cynicism and disrespect for the law, demeans participants, and reinforces shoddy lawyering, blas. . judging, and, at times, perjurious and/or corrupt testifying.").

${ }^{38}$ In the first instance, those subject to AOT laws are not subject to the inpatient involuntarycivil-commitment power but may still be in danger of deterioration in the absence of forced treatment. In the second instance, those subject to SVPAs are those who have been charged and/or convicted of violent sexual offenses and who are targeted as potentially recidivistic pedophiles. In the third instance, those found not guilty by reason of insanity are those who have been found not responsible for the antecedent criminal action. And in the fourth instance, those subject to shuttling from hospitals to prisons for minor crimes are often persons charged with crimes that basically involve "nuisance activities."

39 The topic and substance of this article has been part of previous addresses by one of the authors for nearly two decades. E.g., Michael L. Perlin, Lecture at Waseda University on Current Issues in Disability Law in the United States (Oct. 2007); Michael L. Perlin, Keynote Address at the Annual Meeting of the American Association of Psychiatry and the Law (Oct. 2002); Michael L. Perlin, Keynote Address at First International Conference on Forensic Mental Health Services (Apr. 2001). That author has also raised the issue, albeit fleetingly, in Perlin, ADA Impact on Criminal Defendant Institutionalization, supra note 6, at 195-96, and in Michael L. Perlin, "There's No Success Like Failure/And Failure's No Success at All": Exposing the Pretextuality of Kansas v. Hendricks, 92 Nw. U. L. REV. 1247, 1270 (1998) [hereinafter Perlin, Exposing Pretextuality in Hendricks] (noting that Kansas v. Hendricks, 521 U.S. 346 (1997), "strains to characterize a punitive statute-the most punitive of any of the new generation of SVPAs - as 'civil,' in a way that can only be called 'pre- 
paid to this phenomenon of "blurring" in mental disability law, ${ }^{40}$ though more attention has frequently been paid to the issue of blurring in civil and criminal law in general. ${ }^{41}$

There are other developments in mental disability law that positively "blur" the civil/criminal borderline but which the authors are, by and large, comfortable. One example is the expansion of mental health courts. ${ }^{42} \mathrm{We}$ believe these courts have the capacity to offer a significant measure of dignity to those litigants who appear before them, and that they, to this point, have proven to be extremely effective in reducing recidivism. ${ }^{43}$ Although we do have concerns about the operations of these

textual'"), Michael L. Perlin, An Internet-Based Mental Disability Law Program: Implications for Social Change in Nations with Developing Economies, 40 FoRDHAM INT'L L.J. 435, 437 (2007) ("[Recent years have seen] a widening of the net that, by blurring the boundaries of civil and criminal mental disability law, has increased the categories of persons subject to the involuntary civil commitment power to now include those charged with certain sexually violent offenses and persons subject to 'assisted outpatient commitment."').

${ }_{40}$ Little attention has been paid otherwise. For some examples, see Grant Morris, Punishing the Unpunishable-The Abuse of Psychiatry to Confine Those We Love to Hate, $30 \mathrm{~J}$. AM. ACAD. PSYCHIATRY \& L. 556, 562 (2002) ("When psychiatry is used to substitute special civil commitment for criminal incarceration, we punish the unpunishable.") and Stephen J. Morse, Uncontrollable Urges and Irrational People, 88 VA. L. REV. 1025, 1025 (2002) ("Incarceration, whether in a prison or a treatment facility, requires weighty justification in a society committed to the protection of civil liberty.").

${ }_{41}$ E.g., Rachel Jones, Excessively Unconstitutional: Civil Asset Forfeiture and the Excessive Fines Clause in Virginia, 25 WM. \& MARY BILL RTS. J. 1393, 1393 (2017) (discussing both when assets are seized in connection with forfeiture and with criminal investigations); Lisa L. Casey, Twenty-Eight Words: Enforcing Corporate Fiduciary Duties through Criminal Prosecution of Honest Services Fraud, 35 DEL. J. CORP. L. 1, 87 (2010) ("A robust literature explores how the enlargement of federal criminal law, an expansion that began in the mid-twentieth century, if not earlier, has blurred the traditional distinctions between civil law and criminal law."); Carol S. Steiker, Punishment and Procedure: Punishment Theory and the Criminal-Civil Procedural Divide, 85 GEO. L.J. 775, 783-84 (1997); John C. Coffee, Paradigms Lost: The Blurring of the Criminal and Civil Law Models-And What Can Be Done about It, 101 YALE L.J. 1875, 1888 (1992); Mary M. Cheh, Constitutional Limits on Using Civil Remedies to Achieve Criminal Law Objectives: Understanding and Transcending the Criminal-Civil Law Distinction, 42 HASTINGS L.J. 1325, 1354-55 (1991). Similarly, commentators have looked at the "hybridization" of civil and criminal law. E.g., Jennifer Hendry \& Colin King, Expediency, Legitimacy and the Role of Law: A Systems Perspective on Civil/Criminal Procedural Hybrids, 11 CRIM. L. \& PHIL. 733, 734 (2017); cf. Tradesman Int'l, Inc. v. Kahoe, No. 74420, 2000 WL 283081, at *8 (Ohio Ct. App. Mar. 16, 2000) (Kilbane, J., concurring in part \& dissenting in part) (discussing how civil and criminal contempt sanctions "blur").

${ }_{42}$ See Michael L. Perlin, "Who Will Judge the Many When the Game is Through?": Considering the Profound Differences Between Mental Health Courts and "Traditional" Involuntary Civil Commitment Courts, 41 SEATTLE U. L. REV. 937, 950 (2018) [hereinafter Perlin, Difference of MHCs] ("Because [Mental Health Courts (MHCs)] can divert persons with mental disabilities out of the criminal justice system (where they are likely to be treated as third- or fourth-class citizens, if those terms have any meaningful content or context."), MHCs make it less likely that the person with mental disabilities will suffer at the hands of others because of that status.. Also significant is the related expansion of veterans' courts. See, e.g., Michael L. Perlin, "John Brown Went Off to War": Considering Veterans' Courts as Problem-Solving Courts, 37 NovA L. REV. 445, 456 (2013) [hereinafter Perlin, Veterans' Courts as Problem-Solving Courts]; see generally Julie Marie Baldwin, Investigating the Programmatic Attack: A National Survey of Veterans Treatment Courts, 105 J. CRIM. L. \& CRIMINOLOGY 705, 705 (2015).

${ }_{43}$ See, e.g., Greg Goodale, Lisa Callahan \& Henry J. Steadman, What Can We Say About Mental Health Courts Today?, 64 PSYCHIATRIC SERVS. 298, 298 (2013) ("[T]here is ample evidence that they reduce recidivism and increase participation in community-based treatment."); see also Allison Redlich \& Woojae Han, Examining the Links Between Therapeutic Jurisprudence and Mental Health Court Completion, 38 LAW \& HUM. BEHAV. 109, 109 (2014) [hereinafter Redlich \& Han] 
mental health courts in some jurisdictions, ${ }^{44}$ we believe that, unlike the other developments that cause negative "blur," the expansion of these courts is positive in that it offers the promise of extending (not reducing) due-process protections in an arena that authentically gives weight to the litigant's voice and provides an important modicum of procedural justice. ${ }^{45}$ A second example of positive "blur" with which we are also comfortable is the application of the Americans with Disabilities Act (ADA) ${ }^{46}$ to individuals subject to the criminal justice system. ${ }^{47}$ These two examples in no way detract from our general concern about negative "blur" in mental disability law for the four categories of individuals previously mentioned.

In Part I of this article, we will first trace the development of the dichotomous mental disability law system, with a special focus on the right to refuse treatment. In Part II, we will discuss negative blurring caused by developments in laws governing AOT, SVPAs, imprisonment of insanity acquittees, and continuity of care-or lack thereof-for those shuttled from hospitals to prisons for minor crimes. We will also discuss the negative blurring effects for each of these four areas. In Part III, we discuss some implications of blurring for all of disability law generally, including those areas that may serve to, optimally, limit pretextuality. ${ }^{48}$

(noting that "the courts typically identify those most in need, develop individualized treatment needs, and ultimately aim to decrease recidivism").

${ }^{44}$ See, e.g., E. Lea Johnston \& Conor Flynn, Mental Health Courts and Sentencing Disparities, 62 VILL. L. REV. 685, 693 (2017) (discussing an empirical study of mental health courts in Erie County, PA, and concluding "that anticipated treatment court sentences-for all grades of offensetypically exceed county court sentences by more than a year").

45 See, e.g., Mark R. Munetz et al., Mental Health Court and Assisted Outpatient Treatment: Perceived Coercion, Procedural Justice, and Program Impact, 65 PSYCHIATRIC SERVS. 352, 352 (2014) (stating that mental health court graduates perceived significantly less coercion and more procedural justice in court than did those involved in assisted outpatient treatment proceedings); see generally PERLIN \& CuCOlO, CIVIL AND CRIMINAL, supra note $6, \S 1-2.2 .3$, at 1-32 to 1-36 (providing an overview of the creation of mental health courts).

46 Americans with Disabilities Act, 42 U.S.C. $\$ 12101-12213$ (2012).

47 See generally Perlin, ADA Impact on Criminal Defendant Institutionalization, supra note 6 (discussing the application of the ADA to criminal detainees); Weinstein \& Perlin, Cycle Deprives Contimuity of Care, supra note 35 (outlining how disabled persons cycle through the criminal justice system). The Supreme Court had an opportunity to weigh in on this issue relatively recently, but eventually declined to do so. In City of San Francisco v. Sheehan, 743 F. 3d. 1211 (2014) (requiring police officers to accommodate a disability in arrest), reversed in part \& cert. dismissed in part, 135 S. Ct. 1765 (2015), the Court did not directly decide the question as to whether the ADA applies to arrests. It did state that arrests would be subject to Title II of the ADA if the arrest constitutes an activity in which the arrestee participates or may benefit from the activity, and if the officer's failure to arrest in a manner that reasonably accommodates the individual's disability constitutes discrimination. Id. at 1774 .

48 On the meaning of "pretextuality," see Perlin, Counsel's Role in Right to Refuse Treatment, supra note 37 and accompanying text; Deborah A. Dorfman, Through a Therapeutic Jurisprudence Filter: Fear and Pretextuality in Mental Disability Law, 10 N.Y. L. SCH. J. HUM. RTS. 805, 807-08 (1993) ("[I]nvoluntary treatment given to the mentally disabled ... [is] pretextual because it is often prescribed for the wrong reasons and has a significant negative impact."); Michael L. Perlin \& Naomi Weinstein, "Said I, 'But You Hove No Choice"”: Why a Lawyer Must Ethically Honor a Client's Decision About Mental Health Treatment Even If It Is Not What S/he Would Have Chosen, 15 CARDOZO PUB. L., POL'Y \& ETHICS J. 73, 84-85 (2016) (illustrating how pretextuality plays out in courtrooms). For a thoughtful consideration of how solution-based courts can combat pretextuality (without that characterization) in this area of law and policy, see generally Michelle Edgely, Solution-Focused Court Programs for Mentally Impaired Offenders: What Works?, 22 J. JUD. ADMIN. 
In Part IV, we discuss some positive areas of blurring, including mental health courts and the ADA. In Part V, we briefly discuss some other "blur questions" that have not been extensively explored. In Part VI, we look at the developments that are causing negative blur from the perspectives of therapeutic jurisprudence and conclude with some modest recommendations. ${ }^{49}$

The title for this article comes from Bob Dylan's Desolation Row, ${ }^{50}$ a song whose lyrics invoke an "image of the world ... far removed from marches toward social progress." 51 This song has inspired the title of a past article written by one of the authors, ${ }^{52}$ and has been said to provide an example of "unjust condemnation of the sensitive, isolated individual striving for transcendence by a society out of touch with reality or moral truth that forces conformity to its own arbitrary and absurd rules based on the selfish desires and fantasies of those in possession of power. ${ }^{, 53}$ It also has been described as "a repository for all the world's accumulated hopes, fears, nightmares, and other dreams[-]the ultimate testingground of human experience." 54 The world of Desolation Row is a "deliberate cultural jumble" without depth built on "general deviance" from the normal characteristics of its inhabitants. ${ }^{55}$ Similarly, mental disability law has become so blurred as to be jumbled in a way that is similarly, again, "far removed from marches toward social progress." $\mathrm{We}$ believe that Dylan's lyrics also serve as a perfect metaphor for the questions discussed in this article. ${ }^{57}$

207 (2013).

49 Generally beyond the scope of this article is how international human rights law, especially the United Nations Convention on the Rights of Persons with Disabilities (CRPD), influences the blurring effects and can be used to combat the effects of pretextuality. Michael L. Perlin, " $A$ Change Is Gonna Come": The Implications of the United Nations Convention on the Rights of Persons with Disabilities for the Domestic Practice of Constitutional Mental Disability Law, 29 N. ILL. U. L. Rev. 483,487 (2009). The authors expect to tackle that issue in a future article. See, e.g., Mehgan Gallagher \& Michael L. Perlin, "The Pain I Rise Above": How International Human Rights Can Best Realize the Needs of Persons with Trauma-Related Mental Disabilities, 29 FLA. J. INT'L L. 271, 29096 (2018).

so BOB DYLAN, DESOLATION Row (Columbia 1965).

51 ROBERT SHELTON, NO DiRECTION HOME: THE LIFE AND MUSIC OF BOB DYLAN 283 (Da Capo ed., 1997).

52 See, e.g., Michael L. Perlin, "Everybody Is Making Love/Or Else Expecting Rain": Considering the Sexual Autonomy Rights of Persons Institutionalized Because of Mental Disability in Forensic Hospitals and in Asia, 83 WASH. L. REV. 481, 486-487 (2008) [hereinafter Perlin, Sexual Autonomy in Forensic Hospitals and in Asia]

${ }_{53}$ Anonymous, Desolation Row, as quoted in Perlin, Sexual Autonomy in Forensic Hospitals and in Asia, supra note 52 , at 487.

54 Adam Lively, Adolescence Now, in THE DYLAN Companion: A Collection of Essential WRITING ABOUT BOB DYLAN 198, 208 (Elizabeth Thomson \& David Gutman eds., 1990).

35 Frank Kermode \& Stephen Spender, The Metaphor at the End of the Funnel, in THE DYLAN COMPANION: A COLLECTION OF ESSENTIAL WRITING ABOUT BOB DYLAN 155, 158-59 (Elizabeth Thomson \& David Gutman eds., 1990).

56 SHELTON, supra note 51, at 283.

57 On the other hand, at least one law-review article has argued that at the heart of Desolation Row is an exploration of "the erotic relationship [that] must be governed by a keeping of promises." Adam Gearey, Outlaw Blues: Law in the Songs of Bob Dylan, 20 CARDozo L. REV. 1401, 1406-07 (1999). We disagree with Gearey and believe that Desolation Row is, at its heart, a profound social 


\section{How MOdeRn MENTAL Disability LaW DeVEloped.}

Modern mental disability law developed in the early 1970 s from a trilogy of court cases based on constitutional due process. To this day, these cases still form the foundation of this area of practice. ${ }^{58}$ The trilogy began in 1971 when a federal district court in Alabama found that patients had a constitutional due-process right to treatment. ${ }^{59}$ In 1972 , a three-judge panel for federal district court in Wisconsin found that both procedural and substantive due process applied to involuntary civil commitment decisionmaking ${ }^{60}$ and incorporated principles ${ }^{61}$ underlying what would become the concept of the "least restrictive alternative" (LRA). In that same year, the Supreme Court found that the due process clause governed the "nature and duration" of commitment. ${ }^{62}$

From these cases-Wyatt v. Stickney, Lessard v. Schmidt, and Jackson $v$. Indiana, respectively-and from the Supreme Court's 1975 "right to liberty" decision in $O^{\prime}$ Connor $v$. Donaldson ${ }^{63}$ have flowed virtually all contemporary commitment and institutional rights law. ${ }^{64}$ Subsequent Supreme Court cases tempered somewhat the impact of $W y a t t$; for example,

commentary. Of course, we could be wrong.

${ }_{58}$ See, e.g., Michael L. Perlin, "Abandoned Love": The Impact of Wyatt v. Stickney on the Intersection Between International Human Rights and Domestic Mental Disability Law, 35 LAW \& PSYCHOL. REV. 121, 126 (2011) [hereinafter Perlin, Impact of Wyatt on International and Domestic Intersection] (quoting Milton Greenblatt, Foreword, in Harry C. Schnibbe, Changes in State Mental Health Service Systems Since Wyatt, in WYATT v. STICKNEY: RETROSPECT AND PROSPECT x (L. Ralph Jones \& Richard R. Parlour eds., 1981) which characterizes Wyatt v. Stickney, 325 F. Supp. 781 (M.D. Ala. 1971) as the "foundation of modern psychiatric jurisprudence"); see also Perlin, Impact of Wyatt on International and Domestic Intersection, supra note 58, at 121 ("Wyatt v. Stickney is the most important institutional rights case litigated in the history of domestic mental disability law.").

59 Wyatt, 325 F. Supp. at 784-85 ("To deprive any citizen of his or her liberty upon the altruistic theory that the confinement is for humane therapeutic reasons and then fail to provide adequate treatment violates the very fundamentals of due process.").

to See Lessard v. Schmidt, 349 F. Supp. 1078, 1093 (E.D. Wis. 1972) ("We agree that, to the extent the statute permits a judge or jury to commit a person upon a preponderance of the evidence, it violates fundamental notions of due process ... Although attempts to predict future conduct are always difficult, and confinement based upon such a prediction must always be viewed with suspicion, we believe civil confinement can be justified in some cases if the proper burden of proof is satisfied and dangerousness is based upon a finding of a recent overt act, attempt or threat to do substantial harm to oneself or another.").

61 See id. at 1096 ("We believe that the person recommending full-time involuntary hospitalization must bear the burden of proving (1) what alternatives are available; (2) what alternatives were investigated; and (3) why the investigated alternatives were not deemed suitable.").

${ }_{62}$ Jackson v. Indiana, 406 U.S. 715, 738 (1972) ("At the least, due process requires that the nature and duration of commitment bear some reasonable relation to the purpose for which the individual is committed.").

63 O'Connor v. Donaldson, 422 U.S. 563, 573 (1975) ("Specifically, there is no reason now to decide whether mentally ill persons dangerous to themselves or to others have a right to treatment upon compulsory confinement by the State, or whether the State may compulsorily confine a nondangerous, mentally ill individual for the purpose of treatment. As we view it, this case raises a single, relatively simple, but nonetheless important question concerning every man's constitutional right to liberty." (emphasis added)).

64 See generally PERLIN \& CUCOLO, CIVIL AND CRIMINAL, supra note 6, chs. 7-9. 
the 1982 decision in Youngberg v. Romeo ${ }^{65}$ stopped short of finding a constitutional right to treatment ${ }^{66}$ and side-stepped imposing the LRA requirement, substituting instead the more pallid and puzzling "reasonably non-restrictive confinement conditions" test. ${ }^{67}$ Accordingly, not all federal courts have endorsed the Lessard's LRA requirement. ${ }^{68}$ But these four early cases are clearly the major building blocks of almost fifty years of constitutional, statutory, regulatory, and customary developments. ${ }^{69}$ To this day, they are cited by courts ${ }^{70}$ and deconstructed anew by academics, ${ }^{71}$ with particular focus on Wyatt. ${ }^{72}$ Indeed, it was not until 2004 - more than thirty years after Wyatt was initially filed - that the Alabama district court signed the final order ending the litigation in light of state compliance. ${ }^{73}$

65 Youngberg v. Romeo, 457 U.S. 307 (1982).

66 See id. at 319 (discussing the right to "minimally adequate or reasonable training to ensure safety and freedom from undue restraint" and stating that, "[i]n view of the kinds of treatment sought by respondent and the evidence of record, we need go no further in this case").

67 See id. at 324 ("Respondent thus enjoys constitutionally protected interests in conditions of reasonable care and safety, reasonably nonrestrictive confinement conditions, and such training as may be required by these interests."); Perlin, Will Olmstead Resuscitate the LRA, supra note 13, at 1002 (explaining how this test "slowed doctrinal expansion" in this area of law).

68 See also Perlin \& CuCOLO, CIVIL AND CRIMINAL, supra note 6, § 4-2.1.5, at 4-19 to 4-20 (discussing, inter alia, French v. Blackburn, 428 F. Supp. 1351 (M.D. N.C. 1977)).

69 For an acknowledgement of the importance of Wyatt in particular, see PERLIN \& CUCOLO, CIVIL AND CRIMINAL, supra note 6, $\S 7-3.1$, at 7-32 ("Wyatt remains the most significant case in the history of forensic psychiatry.") (citation omitted) and Perlin, Impact of Wyatt on International and Domestic Intersection, supra note 58, at 121 ("Wyatt v. Stickney is the most important institutional rights case litigated in the history of domestic mental disability law.").

70 See, e.g., People v. Egle, 57 N.Y.S.3d 362, 364-66 (Sup. Ct. 2017) (discussing Jackson v. Indiana, 406 U.S. 715 (1972)); Det. of D.W. v. Dep't of Soc. and Health Servs., 332 P.3d 423, 426 (Wash. 2014) (quoting Wyatt v. Stickney, 325 F. Supp. 781, 784-85 (M.D. Ala. 1971)); In re Michael H., 856 N.W.2d 603, 611 (Wis. 2014) (discussing and quoting Lessard v. Schmidt, 349 F. Supp. 1078 (E.D. Wis. 1972)).

${ }_{71}$ See, e.g., Perlin, Will Olmstead Resuscitate the LRA, supra note 13, at 1013-14, 1022, 1051 (discussing Lessard, Jackson, and later aspects of Wyatt); see also Zachary Groendyk, "It Takes a Lot to Get into Bellevue": A Pro-Rights Critique of New York's Involuntary Commitment Law, 40 FORDHAM URB. L.J. 549, 553 (2012) (discussing Wyatt and Lessard); Donald Stone, There Are Cracks in the Civil Commitment Process: A Practitioner's Recommendations to Patch the System, 43 FORDHAM URB. L.J. 789, 794798 (2016) (discussing Lessard). On the therapeutic-jurisprudence implications of this trilogy, see Michael L. Perlin, Keri K. Gould \& Deborah A. Dorfman, Therapeutic Jurisprudence and the Civil Rights of Institutionalized Mentally Disabled Persons: Hopeless Oxymoron or Path to Redemption? 1 PSYCHOL. PUB. POL'Y \& L. 80 (1995), reprinted in LAW IN A THERAPEUTIC KEY: DEVELOPMENTS IN THERAPEUTIC JURISPRUDENCE 739 (David B Wexler \& Bruce J. Winick eds. 1996). See also, e.g., Robert D. Miller, Patient Responsibilities: The Other Side of the Coin, 17 T.M. COOLEY L. REV. 91, 91 (2000); Susan Stefan, The Americans with Disabilities Act and Mental Health Law: Issues for the Twenty-First Century, 10 J. CONTEMP. LEGAL ISSUES 131, 131 (1999) (grouping and discussing Lessard, Jackson, and Wyatt).

Perlin, Impact of Wyatt on International and Domestic Intersection, supra note 58, at 12 ("[Wyatt's] historic role as a beacon and inspiration has never truly faded. It has been cited (at least) an astounding 411 times in domestic law journals."). As of November 9, 2017-six years following the 2011 publication of Perlin, Impact of Wyatt on International and Domestic Intersection, supra note 58-Wyatt was cited an additional 127 times according to a search of the Westlaw database. For examples, see Jack Drake, Drafting the Cases: The Parallel Legacies of Wyatt v. Stickney and Lynch v. Baxley, 35 LAW \& PSYCHOL. REV. 167 (2011) (discussing Wyatt); Clifton Slaten, The 1995 Wyatt Litigation: Beginnings, Trial Strategies, and Results, 35 LAW \& PSYCHOL. REV. 179 (2011) (same); Frederick E. Vars, Subversive Apologia, 35 LAW \& PSYCHOL. REV. 109 (2011) (same).

73 Wyatt ex rel. Rawlins v. Sawyer, 219 F.R.D. 529, 532-33 (M.D. Ala. 2004) ("The Wyatt 
This initial trilogy of courts sharply distinguished criminal and civil disability law. The Wyatt court distinguished between constitutional protections for institutionalized mental patients and criminals; it noted that the patients at particular hospital, "for the most part, were involuntarily committed through noncriminal procedures and without the constitutional protections that are afforded defendants in criminal proceedings." ${ }^{74}$ The Lessard court applied the principles of the LRA requirement only to involuntary-civil-commitment decisionmaking, noting that "[i]t seems clear ... that persons suffering from the condition of being mentally ill, but who are not alleged to have committed any crime, cannot be totally deprived of their liberty if there are less drastic means for achieving the same basic goal. ${ }^{75}$ Earlier in the opinion, the Lessard court also spelled out that the protections and safeguards in confinement proceedings depend on whether the proceeding was criminal or civil:

The power of the state to deprive a person of the fundamental liberty to go unimpeded about his or her affairs must rest on a consideration that society has a compelling interest in such deprivation. In criminal cases, this authority is derived from the police power, granted because of the necessity of protecting society from anti-social actions. This power is tempered with stringent procedural safeguards designed to protect the rights of one accused of crime, to assure that no one will be arrested except upon probable cause nor convicted of a crime except in conformity with these procedural rules. In civil commitment proceedings the same fundamental liberties are at stake. State commitment procedures have not, however, traditionally assured the due process safeguards against unjustified deprivation of liberty that are accorded those accused of crime. ${ }^{76}$

standards have had a reverberating impact on state and national law, and, perhaps even more importantly, on public consciousness about mental illness. The standards have been incorporated into state and federal mental-health codes and regulations. The concept of treatment in the "least restrictive setting' contained in the Wyatt standards was 'echoed' in the Americans with Disabilities Act of 1990, as the Supreme Court affirmed in 1999 in Olmstead v. L.C. ex rel. Zimring, 527 U.S. 581 (1999). The nationwide Protection and Advocacy system is a 'direct descendant' of the Human Rights Committees Judge Johnson appointed in the Wyatt case. Part of Judge Johnson's March 1972 opinion enumerating rights due the plaintiff class, such as the right to privacy, the right to be treated with dignity, and the right to be free of unnecessary medication and physical restraint, has come to be known among mental-health professionals as a "bill of rights for patients." (internal citations omitted)).

74 Wyatt, 325 F. Supp. at 784 ("When patients are so committed for treatment purposes they unquestionably have a constitutional right to receive such individual treatment as will give each of them a realistic opportunity to be cured or to improve his or her mental condition. Adequate and effective treatment is constitutionally required because, absent treatment, the hospital is transformed 'into a penitentiary where one could be held indefinitely for no convicted offense.' The purpose of involuntary hospitalization for treatment purposes is treatment and not mere custodial care or punishment." (internal citations omitted)).

75 Lessard, 349 F. Supp. at 1096 (emphasis added).

76 Id. at 1084. 
While Wyatt and Lessard dealt with civil commitment, the Jackson court dealt with a case involving a criminal prosecution. ${ }^{77}$ The narrow question before the Court there was whether a person could be institutionalized indefinitely, without a civil commitment proceeding, solely because of incompetence to stand trial in a criminal case. ${ }^{78}$ In finding as a matter of constitutional law that he could not be, the Court laid one of the key foundational points of all modern mental disability law: "At the least, due process requires that the nature and duration of commitment bear some reasonable relation to the purpose for which the individual is committed." ${ }^{, 79}$ As a result, the Court held that a person institutionalized solely because of incompetence to stand trial "cannot be held more than the reasonable period of time necessary to determine whether there is a substantial probability that he will attain that capacity in the foreseeable future." ${ }^{80}$ Without such substantial probability, the person must either be released or become subject to a "customary civil commitment proceeding., 81

Both the Wyatt and Lessard courts premised their decisions, to some extent, on the fact that the plaintiffs in the cases before them had not been convicted of a crime. ${ }^{82}$ And then, three years after Jackson, the Supreme Court in Donaldson stated that "[a] finding of 'mental illness' alone cannot justify a State's locking a person up against his will and keeping him indefinitely in simple custodial confinement." ${ }^{, 83}$ The Court further held that "a State cannot constitutionally confine without more a nondangerous individual who is capable of surviving safely in freedom by himself or with the help of willing and responsible family members or friends. $" 84$ In addition, while these statements were made in the context of a case involving civil commitment, this protection interestingly appeared to apply to what the Court characterized as "every man's constitutional right to liberty," 85 evidencing potential blurring of the protections from confinement civilly and criminally.

Subsequent courts interpreting these cases regularly blurred the rights and protections of mental disability law between criminal and civil contexts, but in a way that caused no untoward or negative consequenc-

\footnotetext{
77 Jackson v. Indiana, 406 U.S. 715, 717 (1972).

78 Id. at 720 (concluding that "on the record before us, Indiana cannot constitutionally commit the petitioner for an indefinite period simply on account of his incompetency to stand trial on the charges filed against him" and noting that the Indiana law at issue in that case did not provide "for periodic review of the defendant's condition by either the court or mental health authorities").

$79 \quad$ Id. at 737.

${ }^{80} \mathrm{Id}$.

81 Id.

82 Wyatt v. Stickney, 325 F. Supp. 781,784 (M.D. Ala. 1971); Lessard, 349 F. Supp. at 1099 n.27.

83 O'Connor, 422 U.S. at 575.

${ }^{84} O^{\prime}$ Connor, 422 U.S. at 576.

85 Id. at 573 ("As we view it, this case raises a single, relatively simple, but nonetheless important question concerning every man's constitutional right to liberty.") (emphasis added).
} 
es. One of the first cases after Wyatt to endorse a similar right to treatment was Davis v. Watkins. ${ }^{86}$ Almost all of the plaintiffs in that case were institutionalized following involvement in the criminal process. ${ }^{87}$ The LRA principles, first developed in Lessard, were subsequently relied upon in cases involving prisoners transferred to mental hospitals and insanity acquittees seeking release ${ }^{88}$ And Jackson's requirement that the "nature and duration" bear a "reasonable relation" to the purpose of commitment has been applied to all categories of commitments including that of sexually violent predators and others. ${ }^{89}$ Furthermore, holdings in criminal cases such as Jackson were applied to civil cases on the unexceptional, and usually unarticulated, theory that it would make little sense that a person neither accused of nor convicted of a crime would have fewer rights than a person who had. ${ }^{90}$

When attention turned to the right to refuse treatment, the distinctions were initially made, as with previous distinctions discussed above,

86 Davis v. Watkins, 384 F. Supp., 1197 (N.D. Ohio 1974) ("The Court has carefully studied [Wyatt] and agrees almost totally with the reasoning of that case and the remedies announced therein. Many of these paragraphs have been excerpted verbatim from that opinion.").

${ }^{87}$ Id. at $1200-03$ (consisting of a class of patients who had been committed to state hospital while on parole, committed after criminal conviction, retained beyond their maximum criminal sentence, transferred from civil institutions or from penal institutions or found incompetent to stand trial or not guilty by reason of insanity).

${ }_{88}$ See, e.g., In re Portus, 371 N.W.2d 871, 872-73 (Mich. Ct. App. 1985) (finding that the trial court should have considered alternatives to hospitalization and whether continued hospitalization was correct for a man who was institutionalized following his acquittal by reason of insanity); In re Commitment of J.L.J., 481 A.2d 563, 565-67, 569-71 (N.J. Super. Ct. App. Div. 1984) (concluding that three former defendants, who were found not guilty of their respective crimes by reason of insanity and subsequently institutionalized, had a constitutional right to the least restrictive environment appropriate to both the protection of society and the defendants' individual rights); Perlin, Will Olmstead Resuscitate the LRA, supra note 13, at 1001 (citing relevant cases); $i d$ at $1001 \mathrm{n} .10-11$ (same); see also Johnson v. Levine, 450 F. Supp. 648, 657-58 (D. Md. 1978) (holding that actively psychotic prisoners and others needing treatment should be transferred from an overcrowded prison to an appropriate state mental institution), aff'd in part and remanded in part on other grounds, 588 F.2d 1378 (4th Cir. 1978); United States ex rel. Souder v. Watson, 413 F. Supp. 711, 717 (M.D. Pa. 1976) (requiring the same due process guarantees afforded to prisoners committed to mental hospitals as are given to non-prisoners).

${ }_{89}$ See, e.g., Seling v. Young, 121 U.S. 250, 265 (2001) (discussing sexually violent predators and noting that "[o]ur decision today does not mean that respondent and others committed as sexually violent predators have no remedy for the alleged conditions and treatment regime at the Center"); Zinermon v. Burch, 494 U.S. 113, 131 (1990) (discussing voluntary commitments); Jones v. United States, 463 U.S. 354, 368 (1983) (discussing insanity acquittees); Youngberg v. Romeo, 457 U.S. 307, 321 (1982) (discussing right to training); see also Oregon Advocacy Center v. Mink, 322 F.3d 1101, 1122 (9th Cir. 2003) (discussing pretrial detainees awaiting competency evaluations); Francis S. v. Stone, 995 F. Supp. 368, 383 (S.D.N.Y. 1998), aff'd, 221 F. 3d 100 (2d Cir. 2000) (same); Streicher v. Prescott, 663 F. Supp. 335, 3336-39 (D.D.C. 1987) (discussing civil commitments); Clark v. Cohen, 613 F. Supp. 684, 699 (E.D. Pa. 1985) (same).

${ }_{90}$ See Riggins v. Nevada, 504 U.S. 127, 135 (1992) ("Under [Washington v.] Harper, forcing antipsychotic drugs on a convicted prisoner is impermissible absent a finding of overriding justification and a determination of medical appropriateness. The Fourteenth Amendment affords at least as much protection to persons the State detains for trial." (emphasis added)); see also, e.g., Steinkruger v. Miller, 612 N.W. 2d 591, 597 (S.D. 2000) ("If prisoners and pretrial detainees possess the rights recognized in Harper and Riggins, how can mental patients not also possess them?'); Jennifer Gutterman, Waging a War on Drugs: Administering a Lethal Dose to Kendra's Law, 68 FORDHAM L. REV. 2401, 2422 (2000) (quoting Harper, and concluding that its "reasoning leads to the belief that the interest of a mental patient is at least as great, and in fact greater, than a prisoner's right to avoid antipsychotic medication"). 
based on whether the person was confined civilly or criminally. The first "big" federal cases addressing whether and to what extent there was a right to refuse treatment came in 1982 with Rennie $v$. Klein ${ }^{91}$ and Rogers v. Okin, ${ }^{92}$ both involving classes of civil patients. As would be important for future distinctions with respect to this right, the forerunner cases on which Rogers and Rennie relied-both explicitly and implicitly-all flowed from the processes of criminal trials. ${ }^{93}$ When Rennie and Rogers caused the Supreme Court to be faced for the first time with the issue, it sidestepped decisions on the merits. ${ }^{94}$ Subsequent state and federal cases decided in their immediate aftermath focused solely on the civil aspects of mental disability law. ${ }^{95}$

But beginning in the late 1980 s, virtually all of the important developments in the right to refuse treatment have flowed from the processes of criminal trials, with radically different distinctions made by courts based on where in the "pipeline" the defendant was at the time of the medication refusal. ${ }^{96}$ Different substantive and procedural standards have been imposed in cases involving, inter alia, the following:

- the right of an incompetent criminal defendant to refuse medication designed to make him competent to stand trial $;^{97}$

91 Rennie v. Klein, 462 F. Supp. 1131 (D.N.J. 1978), supplemented, 476 F. Supp. 1294 (D.N.J. 1979), stay denied in part, granted in part, 481 F. Supp. 552 (D.N.J. 1979), modified and remanded, 653 F. 2d 836 (3d Cir. 1981) (en banc), vacated and remanded, 458 U.S. 1119 (1982).

${ }_{92}$ Rogers v. Okin, 478 F. Supp. 1342 (D. Mass. 1979), modified, 634 F. 2d 650 (1st Cir. 1980) (en banc), vacated sub nom. Mills v. Rogers, 457 U.S. 291 (1982).

${ }_{93}$ See Rennie v. Klein, 462 F. Supp. 1131, 1142-43 (D.N.J. 1978) (relying upon, inter alia, Scott v. Plante, 532 F.2d 939 (3rd Cir. 1976), and applying to insanity acquittee); Mackey v. Procunier, 477 F.2d 877, 877 (9th Cir. 1973) (applying to state prisoner institutionalized at medical facility); Knecht v. Gillman, 488 F.2d 1136, 1136 (8th Cir. 1973) (applying to inmates at state "Security Medical Facility"); PERLIN \& CuCOLO, CIVIL AND CRIMINAL, supra note 6, $\S \S 8-4$ to $8-4.1$, at 8-20 to 822 (discussing relevant cases); Bruce Winick, The Right to Refuse Mental Health Treatment: A First Amendment Perspective, 44 U. MIAMI L. REV. 1, 61-62 (1989) (same). On the ongoing significance of Mackey and Knecht, "mostly lost to the pages of history," see Michael L. Perlin, "And I See Through Your Brain": Access to Experts, Competency to Consent, and the Impact of Antipsychotic Medications in Neuroimaging Cases in the Criminal Trial Process, 2009 STANFORD TECHNOL. L. J. 4, 32-33.

${ }_{94}$ See Mills v. Rogers, 457 U.S. 291, 306 (1982) (remanding for reconsideration in light of state law); Rennie v. Klein, 458, 458 U.S. 1119 (1982) (remanding for reconsideration in light of Youngberg v. Romeo, 457 U.S. 357 (1982)). On the questions left unanswered by these remands, see Perlin \& CUCOlo, Civil AND CRIMINAL, supra note 6, $\S \S 8-5.9 .1$ to 8-5.9.2, at 8-88 to 8-94, and Perlin \& Dorfman, Individual Right to Refuse Treatment, supra note 14, at 152 (discussing how Supreme Court "sidestepped" issue in Mills).

95 PERLIN \& CUCOLO, CIVIL AND CRIMINAL, supra note 6, §§ 8-6.2 to 8-6.3.2, at 8-104 to 8-132.

96 See infra notes $98-100$.

97 See, e.g., Sell v. United States, 539 U.S. 166, 180, 185 (2003) (finding that administration of psychiatric drugs to an incompetent defendant with mental illness is constitutional if the treatment is medically appropriate, unlikely to have side effects that may substantially undermine the faimess of trial, necessary to further government interests, and not replaceable with any adequate less-restrictive alternatives). Sell is also important because, there, the Court stressed the need to engage in a least restrictive alternative analysis, thus recognizing the important liberty interest that a presumedinnocent defendant has in refusing medication. This mode of analysis is significant because, "[i]n addition to providing better quality of treatment, less restrictive alternatives relieve the added stressors of incarceration, and detainment, as they focus primarily on the individual's health and well- 
- the right of a criminal defendant seeking to offer an insanity defense to refuse medication while on trial; ${ }^{98}$

- the right of a mentally ill prisoner to refuse medication; ${ }^{99}$ and

- the right of an incompetent death row inmate to refuse medication designed to make him competent to be executed. $^{100}$

There is patent decisional inconsistency in these opinions. As noted by one of the authors in a previous publication, the "difference in the litigants' legal status self-evidently has no effect on the physiological or neurological potential impact of the drugs in question."101 But in the context of the right to refuse treatment, courts have imposed a new orthodoxy that rejects the previous distinctions of rights and protections solely between civil and criminal contexts; instead, civil patients are treated in one way, incompetent criminal defendants another, insanity-pleading criminal defendants another, prisoners another, and death row inmates yet another. ${ }^{102}$ The decisions of these courts making distinctions within the criminal context seemed to suggest in particular that one of the old orthodoxies of the first generation of modern mental disability law-that, by analogy to the civil context, the standard and procedure should be the same $^{103}$ — was being buried.

being while promoting community integration; the individual can still work, maintain housing, collect benefits, be close to family, and collaborate with his or her attomey." Perlin \& Schriver, Reconsidering Forced Drugging Pre-Trial, supra note 13, at 392-93. See generally Michael L. Perlin, "Salvation" or a "Lethal Dose"? Attitudes and Advocacy in Right to Refuse Treatment Cases, $4 \mathrm{~J}$. FORENSIC PSYCHOL. PRAC. 51 (2004) (discussing the importance of the right to refuse treatment).

${ }_{98}$ See Riggins v. Nevada, 504 U.S. 127, 136 (1992) (finding error where the district court allowed administration of an antipsychotic to a pretrial detainee planning to offer an insanity defense without making any determination of the need for the treatment or any findings for reasonable alternatives).

99 See Washington v. Harper, 494 U.S. 210,227 (1990) (finding that the due process clause allows treatment of an incarcerated person with serious mental illness with antipsychotics against his will if the incarcerated person is dangerous and if the treatment is in his best interest).

${ }_{100}$ See Panetti v. Quarterman, 551 U.S. 930, 959 (2007) ("We likewise find no support elsewhere in Ford [v. Wainwright, 477 U.S. 399 (1986)], including in its discussions of the common law and the state standards, for the proposition that a prisoner is automatically foreclosed from demonstrating incompetency once a court has found he can identify the stated reason for his execution. A prisoner's awareness of the State's rationale for an execution is not the same as a rational understanding of it. Ford does not foreclose inquiry into the latter."); Panetti v. Davis, 863 F.3d 366, 374 (5th Cir. 2017) (finding a full decade after the Supreme Court's decision in Panetti v. Quarterman that state process for seeking determination of competence was ineffective to protect a death penalty prisoner's right to be free from cruel and unusual punishment); see generally, Michael L. Perlin, "Good and Bad, I Defined These Terms, Quite Clear No Doubt Somehow": Neuroimaging and Competency to be Executed after Panetti, 28 BEHAV. SCI. \& L. 671 (2010) (discussing competency to be executed after Panetti).

101 PERLIN \& CuCOLO, CIVIL AND CRIMINAL, supra note 6, § 8-7.2, at 8-163.

102 See supra notes $97-100$.

103 State v. Krol, 344 A.2d 289, 297 (N.J. 1975) (noting that the "the Supreme Court in these opinions has plainly attempted to enunciate a broad principle - that the fact that the person to be committed has previously engaged in criminal acts is not a constitutionally acceptable basis for imposing upon him a substantially different standard or procedure for involuntary commitment. The labels 'criminal commitment' and 'civil commitment" are of no constitutional significance."'); see also Lessard, $349 \mathrm{~F}$. Supp. at 1095 (discussing the use of criminal due process protections in juvenile court as support for stringent standards for all civil commitment because "civil labels and good in- 
The disparate substantive and procedural standards imposed on civil patients and criminal defendants in different parts of the criminal-trial pipeline have become a more urgent issue in the past several years with the proliferation of AOT laws and SVPAs. It is to these statutes that we first turn our attention.

III. AREAS OF "NEGATIVE" BLURRING.

\section{A. Assisted Outpatient Treatment (AOT) Laws. ${ }^{104}$}

The current generation of AOT laws arose in response to fear, stoked by portrayals in the media, of people with dangerous mental illness who allegedly refused community treatment. ${ }^{105}$ In New York, for example, court-ordered AOT is used mainly for people who have a history of multiple hospitalizations. ${ }^{106}$ A person may be subjected to AOT by a New York court if the person meets certain criteria, including being at least eighteen years of age, suffering from a mental illness, being deemed unlikely to survive in the community without supervision, and having a sufficient history of noncompliance with treatment. ${ }^{107}$ Court-ordered

tentions do not themselves obviate the need for criminal due process safeguards in juvenile courts, for " $\mathrm{a}$ ] proceeding where the issue is whether the child will be found to be "delinquent" and subjected to the loss of his liberty for years is comparable in seriousness to a felony prosecution'"); Perlin, ADA Impact on Criminal Defendant Institutionalization, supra note 6, at $195 \mathrm{n} .15$ (noting the importance of the phrase from State v. Krol, 344 A.2d 289 (N.J. 1975)).

104 This section is partially adapted from Michael L. Perlin and Naomi M. Weinstein, "Friend to the Martyr, A Friend to the Woman of Shame": Thinking About the Law, Shame and Humiliation, 24 S. CAL. ReV. L. \& SOC. JUST. 1 (2014) [hereinafter Perlin \& Weinstein, Law, Shame and Humiliation].

105 See, e.g., Henry A. Dlugacz, Involuntary Outpatient Commitment: Some Thoughts on Promoting a Meaningful Dialogue Between Mental Health Advocates and Lawmakers, 53 N.Y.L. SCH. L. REV. 79, 85 (2008) (arguing that media portrayal of mental illness reduces the ability for rational discourse about outpatient commitment); PERLIN \& CUCOLO, CIVIL AND CRIMINAL, supra note 6, § 4-3.3, at 4-177 to 4-187 (discussing that outpatient commitment law actually precedes the "modern era" as exemplified by New York's Kendra's Law by a number of years); see also Candice T. Player, Involuntary Outpatient Commitment: The Limits of Prevention, 26 STAN. L. \& POL'Y REV. 159, 181 (2015) (detailing that North Carolina passed the first outpatient commitment law in 1983).

106 Dlugacz, supra note 105, at 95 (quoting John A. Gresham, Implementation of "Kendra's Law" Is Severely Biased (N.Y. Lawyers for Public Interest, New York, N.Y.), Apr. 7, 2005, at 1, available at http://nylpi.org/pub/Kendras_Law_04-07-05.pdf [https://perma.cc/GP4Y-HK65] as saying that "contrary to how it has been sold, the law is used mainly on people with multiple psychiatric hospitalizations but no histories of hurting others").

107 N.Y. MENTAL HYG. LAW $\$ 9.60$ (c) (2015) (requiring the history of lack of compliance with treatment for mental illness to either include hospitalization under certain circumstances at least twice in the last three years or acts of serious violent behavior under certain circumstances in the last four years, and further noting that the other criterion are that the person "(5) is, as a result of his or her mental illness, unlikely to voluntarily participate in outpatient treatment that would enable him or her to live safely in the community; (6) in view of his or her treatment history and current behav- 
AOT is similar to involuntary inpatient treatment in that it can include forcing a person to take certain medication, to live in a particular place, and in some cases, to attend certain outpatient clinics. ${ }^{108}$

While AOT laws are in theory benign, they often have negative aspects and impacts. AOT laws are meant to enable a person with mental illness to live in the community by providing a case manager, psychiatrist, residential facility, or day-treatment program. ${ }^{109}$ But, through coercion, they negatively blur the borderline between criminal and civil law. Coercion can occur, for example, by threat of confinement; people who are non-compliant may in some cases be "forcibly brought to an emergency room and held in the hospital for seventy-two hours without the option of leaving." 110 This powerlessness appears similar to what is felt by parolees who feel obligated to agree to conditions in order to be released from prison. ${ }^{111}$ As is evident, classification of the treatment as "outpatient" or even "voluntary" does not mean that the process is free from this coercion. ${ }^{112}$

The coercive aspects of AOT laws raise important due process concerns. Forced medication and curtailment of liberty for persons in an outpatient setting fail to adhere to the LRA requirement of ADA and constitutional case law. ${ }^{113}$ AOT laws may also disproportionately coerce

ior, is in need of assisted outpatient treatment in order to prevent a relapse or deterioration which would be likely to result in serious harm to the person or others as defined [elsewhere in] this article; and (7) is likely to benefit from assisted outpatient treatment").

108 See id. (noting that one of the criteria is that the person be "unlikely to voluntarily participate in outpatient treatment"); id. $\S 9.60(n)$ (noting that one of the results of failure to comply, including where the person "refuses to take medications as required by the court order," may be "involuntary admission to a hospital"); see also In re K.L., 806 N.E.2d 480, 480 (N.Y. 2004) (declining to extend Rivers in holding that capacity to make medical decisions was not required for an AOT commitment); Rivers v. Katz, 495 N.E.2d. 337, 344 (N.Y. 1986) (holding that an involuntarily committed patient in a psychiatric hospital could not be medicated over his or her objection, unless the hospital proved by clear and convincing evidence that the person suffers from a mental illness, lacks capacity to make a reasoned decision, and shows that the proposed treatment was the least restrictive alternative and in the patient's best interests).

109 See N.Y. MENTAL HYG. LAW $\S 9.60(a)(1)$ (2015) (discussing therapy, counseling, and supervised living arrangements).

110 Dlugacz, supra note 105 , at 88.

111 Tonja Jacobi, Song Richardson \& Gregory Barr, The Attrition of Rights Under Parole, $87 \mathrm{~S}$. CAL. L. REV. 887, 890 (2014) ("[T] he possibility of being incarcerated for three months for minor or technical violations of parole provides a powerful means of leverage over parolees. Police use this leverage to recruit parolees as confidential informants, a role that places parolees in danger but nonetheless serves an important community policing function. However, it also makes the parolee subject to less altruistic forms of influence. Local criminals and gangs who know the parole status of individuals can use the threat of reporting a violation of the terms of release - real or trumped up - as a basis for coercion. As such, although parole is meant to keep parolees on the path toward reintegration into the community, it actually provides a means of blackmailing parolees into criminality and recidivism.").

112 See, e.g., N.Y. MENTAL HYG. LAW $\$ 9.60$ (using the word "outpatient"). Coercion is also often present in the allegedly voluntary AOT process as well. See PERLIN \& CUCOLO, CIVIL AND CRIMINAL, supra note $6, \S \S 4-3.2$ to 4-3.2.2, at 4-165 to 4-177 (discussing voluntary commitments); Susan C. Reed \& Dan A. Lewis, The Negotiation of Voluntary Admission in Chicago's State Mental Hospitals, 18 J. PSYCHIATRY \& L. 137, 148 (1990) (noting that the most common method for a therapist to obtain consent is through "persuasion and coercion").

113 See supra notes 92-95. We understand that some of these arguments were rejected by the New York Court of Appeals in In re K.L., 1 N.Y. 3d 362 (2004), although the argument regarding the 
racial minorities into involuntary treatment and forced drugging. ${ }^{114}$ And more fundamentally, a judge applying AOT law might often order preventative commitment in response to perceived rather than real risks of the patient to society, and opt not to order more therapeutic treatments such as assisted community treatment. ${ }^{115}$ Rationalization based on perceived risk feeds the misconception that persons with mental illness are inherently more dangerous than others. ${ }^{116}$

The coercive aspects of AOT laws also raise important ethical and treatment-effectiveness concerns. Forcible detainment by police for a psychiatric exam at a hospital for up to twenty-four hours without any finding of dangerousness ${ }^{117}$ is a clear example of one ethically suspect situation. And mandating medication against a person's will arguably devalues that person in a broader sense. ${ }^{118}$ In addition, concerns over the effectiveness of treatment arise when this coercion may impose costs "in terms of diminished patient autonomy and in chilling the willingness of mentally ill persons to seek treatment voluntarily." 119 Court processes can also be generally humiliating because it may shame ${ }^{120}$ people who are frequently hospitalized; such shaming in and of itself can discourage

ADA was not raised in K.L. We also understand that this decision "has made it abundantly clear that Kendra's Law passes constitutional muster" in New York. Edward F. McArdle, 2003-2004 Survey of New York Law: Health Law, 55 SYRACUSE L. REV. 1107, 1141 (2005). Note, however, that the New Mexico Supreme Court has declined to follow K.L. in an outpatient commitment case involving a preemption issue. Prot. and Advocacy Sys. v. City of Albuquerque, 195 P.3d 1, 20 (N.M. 2008).

114 Dlugacz, supra note 105, at 82 (as a possible definition of "Involuntary Outpatient Commitment" as "a legal intervention designed to disproportionately coerce into treatment members of racial minority groups who are labeled as having psychiatric disorders or are victims of a variety of social conditions, notwithstanding the fact that they wish to resist this unwanted treatment which generally includes forced drugging" and citing generally Gresham, supra note 106). On how the public psychiatric system may disproportionately marginalize persons who are racial minorities, see Michael L. Perlin, Pretexts and Mental Disability Law: The Case of Competency, 47 U. MIAMI L. REV. 625, 648 (1993) (discussing how racial prejudices can influence staff workers' beliefs of which patients are worth special attention); Michael L. Perlin \& Heather Ellis Cucolo, "Tolling for the Aching Ones Whose Wounds Cannot Be Nursed": The Marginalization of Racial Minorities and Women in Institutional Mental Disability Law, 20 J. GENDER, RACE \& JUST. 431, 433 (2017); Reed \& Lewis, supra note 112 , at 139 (revealing that community mental health centers staff workers will deviate from their routine behavior and select certain patients for special attention (in the admission and treatment processes) if the workers feel that the specific patients in question are "worth it," a troubling conclusion, given how the assessment as to who is "worth it" can be "easily distorted by prejudices and overgeneralizations about race, sex, sexual preference, ethnicity and social class").

115 See Bruce J. Winick, Outpatient Commitment: A Therapeutic Jurisprudence Analysis, 9 PSYCHOL. PUB. POL'Y \& L. 107, 109 (2003) [hereinafter Winick, Outpatient Commitment TJ Analysis] ("Court-ordered participation in treatment in the community is more preventive commitment than it is assisted community treatment. Is this new approach constitutional? Is it wise?").

${ }_{116}$ See Dlugacz, supra note 105, at 89; Winick, Outpatient Commitment TJ Analysis, supra note 115 , at 109 .

117 See N.Y. MENTAL HYG. LAW $\$ 9.60(\mathrm{~h})(3)(2015)$ (outlining that forcible retention under court order should not last longer than twenty-four hours).

${ }_{118}$ Perlin, TJ \& Kendra's Law, supra note 24, at 191 (citing arguments made in Michael Hoge \& Elizabeth Grottole, The Case Against Outpatient Commitment, 28 J. AM. ACAD. PSYCHIATRY \& L. $165,167(2000))$.

119 Richard C. Boldt, Perspectives on Outpatient Treatment, 49 NEw ENG. L. REV. 39, 80 (2014).

120 On shame and humiliation in the law in this context in general, see Perlin \& Weinstein, Law, Shame and Humiliation, supra note 104. 
attending court-ordered treatment. Court-ordered treatment involves coercion that may "inspire distrust of the therapist, resentment, and lack of genuine cooperation."

AOT laws and other mental health treatment can also cause negative blurring when compliance is made a condition of parole. ${ }^{122}$ Parole officers are not necessarily trained mental health professionals and may not have the necessary expertise to properly assist the parolees with compliance. ${ }^{123}$ Furthermore, as one of the authors previously noted, these developments exacerbate misconceptions, "making it appear to the public that there is a causal connection between mental illness and dangerousness," and thus making it possible that AOT laws like "Kendra's Law may distort- - even further-the public's view of persons with mental illness." 124

In short and as one of the authors previously acknowledged, there is a "host of difficult questions - policy questions, financial questions, legal questions, treatment questions, and political questions-that have not yet been addressed through the courts or other institutions" regarding AOT laws; "[u]ntil these questions are seriously and thoughtfully considered, we will not be able to resolve the core issues with" AOT laws. ${ }^{125}$ And at the core of many of these issues is a negative blurring between criminal and civil mental disability law. ${ }^{126}$

121 See Winick, Outpatient Commitment TJ Analysis, supra note 115, at 119-120 ("Coercion [to attend psychotherapy] is more likely to inspire distrust of the therapist, resentment, and lack of genuine cooperation."). A relatively-recent study in England found that community treatment orderssimilar to AOT laws - are no better and no more prevent readmission to a psychiatric hospital care than do other legal measures that allow patients short periods of leave from psychiatric hospitals. See Tom Burns et al., Community Treatment Orders for Patients with Psychosis (OCTET): A Randomised Controlled Trial, 381 LANCET 1627, 1631 (2013) (discussing how there is no support to justify the significant curtailment of patients' personal liberties).

${ }_{122}$ Joe Meador, The Forced Administration of Psychotropic Drugs and the Conditioning of Parole to Avoid Supreme Court Precedent-Closs v. Weber, 238 F. 3d. 1018 (8th Cir. 2001), 43 S. TEX. L. REV. 763, 767-70 (2002).

${ }^{123}$ See Nikhil Tomar et al., Statewide Mental Health Training for Probation Officers: Improving Knowledge and Decreasing Stigma, 5 HEALTH \& JUST. J. 11, 1 (2017) ("[D]ue to lack of training and knowledge of mental illness, probation officers may perceive probationers with mental illnesses as high-risk offenders who require more surveillance than those without such diagnoses.").

124 Perlin, TJ \& Kendra's Law, supra note 24, at 207 ("By widening the net of persons who can come within the ambit of the public mental health system, by investing certain prison and parole officers with putative mental health 'expertise,' and by making it appear to the public that there is a causal connection between mental illness and dangerousness, Kendra's Law may distort-even further-the public's view of persons with mental illness.").

125 Perlin, TJ \& Kendra's Law, supra note 24, at 202; see also PERLIN \& CUCOLO, CIVIL AND CRIMINAL, supra note 6, § 4-3.3.1, at 4-194 ("Growth here- both statutory and case law-should be fluid and rapid").

${ }^{126}$ It should be emphasized that not all commentators agree with our critique of AOT laws. See Ken Kress, An Argument for Assisted Outpatient Treatment for Persons with Serious Mental Illness Illustrated with Reference to a Proposed Statute for lowa, 85 IowA L. REV. 1269, 1283 (2000) ("In many cases of actual or threatened violence by individuals with mental disorders, an assisted outpatient treatment statute would have protected both the victims and the perpetrator, thereby enhancing public safety and welfare. While the ways in which society's welfare will be enhanced are obvious, the perpetrator's welfare will be enhanced because the perpetrator will not be subject to violent action in self defense, to criminal charges, or to agonizing remorse for his or her actions."); see also McArdle, supra note 113, at 1141 ("There is little question that Kendra's Law will continue to be utilized to ensure public safety and patient health when mentally ill patients return to the communi- 


\section{B. Sexually Violent Predator Acts (SVPAs). ${ }^{127}$}

SVPAs in their modern form first arose in the early 1990s. After the state of Washington-responding to a particularly vivid ${ }^{128}$ and heinous attack $^{129}$ _."revamp[ed] and resurrect[ed] its sex offender involuntary commitment system" in $1990,{ }^{130}$ other states ultimately followed; as of 1997, at least seventeen states had enacted some sort of a "modern" sexoffender statute. ${ }^{131}$ Many were enacted in the wake of New Jersey's 1994 enactment of the original so-called "Megan's Law," which was a response to the heinous murder of seven-year-old New Jersey resident Megan Kanka. ${ }^{132}$ In 1996, the federal government enacted its version of Megan's Law that made preexisting federal provisions more onerous. ${ }^{133}$ These SVPAs grew out of a legislative desire to protect the public from a group of offenders that is widely (and universally) despised: criminals who sexually abuse and molest young children. As written, however, most appear to cover sexually violent acts against all victims. ${ }^{134}$

ty.").

127 This section is partially adapted from PERLIN \& CUCOLO, CIVIL AND CRIMINAL, supra note 6, $\S \S 5-2.2$ to 5-2.4.2, Perlin, Exposing Pretextuality in Hendricks, supra note 39 , and PERLIN \& CUCOLO, DETRIMENTS OF SVP LEGISLATION, supra note 27. See also Heather Ellis Cucolo, \& Michael L. Perlin, Preventing Sex-Offender Recidivism through Therapeutic Jurisprudence Approaches and Specialized Community Integration, 22 TEMPLE POLITICAL \& CIVIL RTS. L. REV. 1, 2 - 5 (2012) [hereinafter Cucolo \& Perlin, Preventing Sex-Offender Recidivism through TJ] (giving an overview of the kinds of laws applying to sex offenders); Heather Ellis Cucolo \& Michael L. Perlin, Promoting Dignity and Preventing Shame and Humiliation by Improving the Quality and Education of Attomeys in Sexually Violent Predator (SVP) Civil Commitment Cases, 28 FLA. J.L. \& PUB. POL'Y 291, 293-296 (2017) [hereinafter Cucolo \& Perlin, Promoting Dignity for SVPs] (discussing two Supreme Court cases and how they apply to Sexually Violent Predator Act cases).

${ }_{128}$ On the impact of one "vivid" case in mental disability law reform in general, see MICHAEL L. PERLIN, THE JURISPRUDENCE OF THE INSANITY DEFENSE (1994) [hereinafter PERLIN, THE JURISPRUDENCE OF THE INSANITY DEFENSE] (discussing the impact of Hinckley on insanity defense law reform). On how the vividness heuristic dominates our social and political discourse, for better or worse see Perlin, Insanity Defense \& Fear of Faking, supra note 36 (defining vividness heuristic as "a cognitive-simplifying device through which a 'single vivid, memorable case overwhelms mountains of abstract, colorless data upon which rational choices should be made")).

129 See Raquel Blacher, Historical Perspective on the "Sex Psychopath" Statute: From the Revolutionary Era to the Present Federal Crime Bill, 46 MERCER L. REV. 889, 908-19 (1995) (discussing the attack of a child that led the Washington legislature to enact a new sexual offender law).

${ }_{130}$ Jeffrey A. Klotz, Sex Offenders and the Law: New Directions, in LAW IN A THERAPEUTIC KEY: DEVELOPMENTS IN THERAPEUTIC JURISPRUDENCE 131, 133 (David Wexler \& Bruce Winick eds., 1997).

131 See, e.g., Kansas v. Hendricks, 521 U.S. 346, 388 (1997) (Breyer, J., dissenting) ("I have found 17 States with laws that seek to protect the public from mentally abnormal, sexually dangerous individuals through civil commitment or other mandatory treatment programs.").

132 N.J. STAT. ANN. $\S \S 2$ C:7-1 to 11 (West 1994); Kimberly J. McLarin, Trenton Races to Pass Bills on Sex Abuse, N.Y. TIMES (Aug. 30, 1994), https://www.nytimes.com/1994/08/30/nyregion/trenton-races-to-pass-bills-on-sex-abuse.html [https://perma.cc/52GN-HP9B] (discussing how quickly the law was enacted after Megan Kanka's death).

${ }^{133}$ Clinton Signs Tougher "Megan's Law", CNN (May 17, 1997), http://edition.cnn.com/ALLPOLITICS/1996/news/9605/17/clinton.sign/index.shtm1 [https://perma.cc/59T7-EZA8]

${ }_{134}$ But see Klotz, supra note 130, at 131 (explaining that legislation has been enacted in "response 
SVPAs differ in content but share certain elements. One common element is that, to involuntarily commit a sex offender, the state must prove by a quantum of either "beyond a reasonable doubt" or "clear and convincing evidence," what has been summarized as the following: "(1) a history of sexually violent acts, (2) a current mental disorder or abnormality, (3) the likelihood of future sexually harmful acts, and (4) a nexus between the first two elements and the third." ${ }^{.135}$ In most of these statutes, commitment is basically indefinite and release is allowed only when it is shown that the offender is no longer dangerous because of mental disorder. ${ }^{136}$

One SVPA, later reviewed by the Supreme Court, was enacted by Kansas in 1994 as a means of institutionalizing a "small but extremely dangerous group of sexually violent predators exist[ing] who do not have a mental disease or defect that renders them appropriate for involuntary treatment pursuant to [its general involuntary civil commitment statute]. ${ }^{.137}$ The Kansas law established a separate commitment process for "the long-term control, care and treatment of sexually violent predators." 138 Sexually violent predators were statutorily defined as "any person who has been convicted of or charged with a sexually violent offense and who suffers from a mental abnormality or personality disorder which makes the person likely to engage in repeat acts of sexual violence and who has serious difficulty in controlling such person's dangerous behavior." 139 Mental abnormality was defined as a "congenital or acquired condition affecting the emotional or volitional capacity which predisposes the person to commit sexually violent offenses in a degree constituting such person a menace to the health and safety of others." 140

Twenty years ago, the Supreme Court upheld the validity of Kansas's SVPA in Kansas v. Hendricks. ${ }^{141}$ There, the Court found that the statute's use of the phrase "mental abnormality" satisfied substantive due process guarantees, ${ }^{142}$ since such phrasing — among other added statutory

to public outcry for protection from sex offenders" generally); N.J. STAT. ANN. § 2C:7-1(b) (West 1994) (noting that "[a] system of registration of sex offenders and offenders who commit other predatory acts against children will provide law enforcement with additional information critical to preventing and promptly resolving incidents involving sexual abuse and missing persons").

${ }_{135}$ Eric Janus, The Use of Social Science and Medicine in Sex Offender Commitment, 23 NEW ENG. J. ON CRIM. \& CIV. CONFINEMENT 347, 348-49 (1997) (analyzing relevant statutes).

${ }^{136} I d$. at 349 (analyzing relevant statutes).

137 Hendricks, 521 U.S. at 351 (citing KAN. STAT. ANN. § 59-29a01 (1994) (preamble)).

138 KAN. STAT. ANN. \& 59-29a01 (preamble).

${ }^{139}$ Id. $\$ 59-29 \mathrm{a} 02$ (a) (emphasis added).

${ }^{140} I d$. $\$ 59-29 \mathrm{a} 02(\mathrm{~b})$. The Act initially pertained to the following sorts of offenders, based on procedural notice requirements: (1) a presently confined person who had been convicted of a "sexually violent offense" and was scheduled for release from prison, (2) a person who had been "charged with a sexually violent offense" but had been found incompetent to stand trial, (3) a person who had been found "not guilty by reason of insanity of a sexually violent offense," or (4) a person found "not guilty" of a sexually violent offense because of a mental disease or defect. See KAN. STAT. ANN. \& 59-29a03(a); see also Hendricks, 521 U.S. at 353 (outlining the procedures for trial and confinement of sexually violent offenders).

${ }^{141}$ Hendricks, 521 U.S. at 346.

${ }^{142}$ Id. at 356. 
requirements - limited involuntary civil confinement to those who "suffer from a volitional impairment rendering them dangerous beyond their control." 143 The Court rejected Hendricks's argument that prior decisions required proof of mental illness sufficient to satisfy what he thought was an objective standard held by the Court, as well as his argument that his "mental abnormality," a term coined by the Kansas legislature, could not be such an illness. ${ }^{144}$ Pedophilia, the Court reasoned, was classified by "the psychiatric profession" as a "serious mental disorder"; this disorder-in Hendricks' case, marked by a "lack of volitional control, coupled with a prediction of future dangerousness"-_"adequately distinguishes Hendricks from other dangerous persons who are perhaps more properly dealt with exclusively through criminal proceedings."145

The Court also rejected Hendricks's arguments that the SVPA established criminal proceedings and thus violated both the double jeopardy and ex post facto provisions of the Constitution. Turning first to Hendricks's double jeopardy arguments, it found that the Act implicated neither "of the two primary objectives of criminal punishment: retribution or deterrence."146 The Court reasoned - as to retribution-that the Act "does not affix culpability for prior criminal conduct," noting that a criminal conviction is not a prerequisite for commitment under the Act. ${ }^{147}$ Further, the Court reasoned, no finding of criminal intent-which according to the Court is "customarily an important element in distinguishing criminal from civil statutes"-is required as a condition precedent to a commitment order. ${ }^{148}$ In addition, the Court rejected Hendrick's argument that the SVPA was punitive for not offering any legitimate treatment, noting it was possible that no acceptable treatment existed. ${ }^{149}$

\footnotetext{
143 Id. at 358 .

144 Id. at 359 (stating that “[c]ontrary to Hendricks' assertion, the term 'mental illness' is devoid of any talismanic significance" and quoting in part Ake v. Oklahoma, 470 U.S. 68, 81 (1985) to note that "[n]ot only do 'psychiatrists disagree widely and frequently on what constitutes mental illness,' but the Court itself has used a variety of expressions to describe the mental condition of those properly subject to civil confinement").

${ }^{145} I d$. at 360 . Hendricks's language sanctioning predictions of future dangerousness has since been cited approvingly frequently. See, e.g., Richard S. v. Carpinello, 589 F.3d 75, 81 (2d Cir. 2009), cert. den. 562 U.S. 951 (2010); Rose v. Mayberg, 454 F.3d 958, 961 (9th Cir. 2006), cert. den. 549 U.S. 1217 (2007); Laxton v. Bartow, 421 F.3d 565, 569 (7th Cir. 2005); United States v. Enjady, 134 F.3d 1427, 1432-33 (10th Cir. 1998), cert. den., 525 U.S. 887 (1998) (same); Francis S. v. Stone, 995 F. Supp. 368, 388 n.126 (S.D.N.Y. 1998) ("[P]revious instances of violent behavior are an important indicator of future violent tendencies.") (quoting Hendricks, 521 U.S. at 358); State v. Rykowski, No. 97APA06-837, 1998 WL 66948, at *2 (Ohio App. Feb. 19, 1998), aff' $d$ 84 Ohio St. 3d 21 (1998) (same); State v. Fugate, No. CA97-03-065, 1998 WL 42232, at *1 (Ohio App. Feb. 2, 1998) ("[F]rom a legal point of view there is nothing inherently unattainable about a prediction of future dangerousness." (quoting Hendricks, 521 U.S. at 357)).

146 Hendricks, 521 U.S. at 361-62.

147 Id. at 362 .

148 Id. at 362 .

149 Hendricks claimed that the Act was punitive because it did not offer any legitimate "treatment." Here, the majority noted that "incapacitation" may be a legitimate end of the civil law and added that it had never held that "the Constitution prevents a State from civilly detaining those for whom no treatment is available, but who nevertheless pose a danger to others." $I d$. at 366 . The Court added that "[a] State could hardly be seen as furthering a 'punitive' purpose by involuntarily confin-
} 
In a later case examining law of the state of Washington, the Supreme Court subsequently returned to the question of whether an SVPA violated both the double jeopardy and ex post facto provisions of the Constitution. The Court in Seling v. Young held that, absent a direct challenge to determination by a state's high court that an SVPA statute was civil rather than criminal, the respondent could not raise an "as-applied" challenge based on conditions of his confinement on double jeopardy and ex post facto grounds. ${ }^{150}$ The Court noted that such a challenge would be "unworkable" because "confinement is not a fixed event," and that "[ $[\mathrm{t}] \mathrm{he}$ civil nature of a confinement scheme cannot be altered based merely on vagaries in the implementation of the authorizing statute." 151 The Court noted, however, that the "respondent and others committed as sexually violent predators" may have a state statutory remedy through state courts for lack of "adequate care and individualized treatment". ${ }^{152}$ The Court followed by noting that these same state courts were also able to hear challenges to civil confinement schemes based on violations of constitutional due process. ${ }^{153}$ For this proposition, the Court cited to Foucha v. Louisiana, ${ }^{154}$ Youngberg v. Romeo, and Jackson v. Indiana. ${ }^{155}$

The requirements for civil precommitment were further confounded by the Court's decision in Kansas v. Crane. ${ }^{156}$ The Court therein revisited its statement in Hendricks that, based on laws the Court has previously upheld, an SVPA or other law seeking precommitment requires generally that it be "difficult, if not impossible, for the person to control his

ing persons afflicted with an untreatable, highly contagious disease." Id. It would be of "little value," the opinion continued, "to require treatment as a precondition for civil confinement of the dangerously insane when no acceptable treatment existed. To conclude otherwise would obligate a State to release certain confined individuals who were both mentally ill and dangerous simply because they could not be successfully treated for their afflictions." Id.

150 Seling v. Young, 531 U.S. 250, 262-64 (2001). ("Here, we evaluate respondent's allegations as presented in a double jeopardy and ex post facto challenge under the assumption that the Act is civil. ... Permitting respondent's as-applied challenge would invite an end run around the Washington Supreme Court's decision that the Act is civil in circumstances where a direct attack on that decision is not before this Court.").

151 Seling v. Young, 531 U.S. 250, 262-64 (2001). ("Here, we evaluate respondent's allegations as presented in a double jeopardy and ex post facto challenge under the assumption that the Act is civil.... Permitting respondent's as-applied challenge would invite an end run around the Washington Supreme Court's decision that the Act is civil in circumstances where a direct attack on that decision is not before this Court.").

${ }_{152} I d$. at 265 ("Our decision today does not mean that respondent and others committed as sexually violent predators have no remedy for the alleged conditions and treatment regime at the Center. The text of the Washington Act states that those confined under its authority have the right to adequate care and individualized treatment. As petitioner [the facility superintendent] acknowledges, if the Center fails to fulfill its statutory duty, those confined may have a state law cause of action. It is for the Washington courts to determine whether the Center is operating in accordance with state law and provide a remedy." (internal citations omitted)).

${ }^{153} I d$. ("State courts, in addition to federal courts, remain competent to adjudicate and remedy challenges to civil confinement schemes arising under the Federal Constitution. ... Accordingly, due process requires that the conditions and duration of confinement under the Act bear some reasonable relation to the purpose for which persons are committed.").

154 Foucha v. Louisiana, 504 U.S. 71 (1992).

155 Young, 531 U.S. at 265.

156534 U.S. 407, 409 (2002). 
dangerous behavior." 157 In clarification, the Court stated that showing lack of control required only circumstantial "proof of serious difficulty in controlling behavior" that "must be sufficient to distinguish the dangerous sexual offender whose serious mental illness, abnormality, or disorder subjects him to civil commitment from the dangerous but typical recidivist convicted in an ordinary criminal [trial]."158 The Court vacated and remanded in Crane, holding that the Constitution does not require that a state prove complete or absolute lack of control, ${ }^{159}$ but by implication does preclude precommitment without any lack-of-control determination at all.

Finally, the Supreme Court in United States v. Comstock upheld a federal civil commitment law ${ }^{160}$ encompassing federal prisoners that gave the Federal Bureau of Prisons the power to detain those deemed "sexually dangerous" even after they had served out their entire sentences. ${ }^{161}$ The Supreme Court rejected a constitutional challenge raised by individuals subject to this commitment scheme, finding that Congress had the authority to create this legislation, like all other of its laws criminalizing conduct, under the Necessary and Proper Clause. ${ }^{162}$ By using this clause as the vehicle of this decision rather than specifying an underlying enumerated power of Congress, the Court "supported the notion that it was necessary and proper for Congress to prevent this 'dangerous' cohort of individuals from entering society." previously noted, this implied that the "majority accepted the fact that sexual predators pose a high risk of dangerousness and that future risk can be determined." $" 164$

157 Hendricks, 521 U.S. at 358. ("The precommitment requirement of a 'mental abnormality' or 'personality disorder' [of the Kansas statute] is consistent with the requirements of these other statutes that we have upheld in that it narrows the class of persons eligible for confinement to those who are unable to control their dangerousness.").

158 Crane, 534 U.S. at 411-13 ("In Hendricks, this Court did not give 'lack of control' a particularly narrow or technical meaning, and in cases where it is at issue, 'inability to control behavior' will not be demonstrable with mathematical precision. It is enough to say that there must be proof of serious difficulty in controlling behavior.").

${ }^{159}$ Id. at 411-12. ("We agree with Kansas insofar as it argues that Hendricks set forth no requirement of total or complete lack of control.").

16018 U.S.C. $\S \S 4247-48$.

161 United States v.Comstock, 560 U.S. 126, 129-30 (2010).

162 Comstock, 560 U.S. at 137 (citing U.S. CONST. art. I, § 8, cl. 18.)

163 Heather Ellis Cucolo \& Michael L. Perlin, "They're Planting Stories in the Press": The Impact of Media Distortions on Sex Offender Law and Policy, 3 U. DENVER CRIM. L. REV. 185, 238-39 (2013) [hereinafter Cucolo \& Perlin, Media Distortions of Sex Offenders] ("Whether or not the Justices writing for the majority were moved or influenced in any way by public sentiment, they supported the notion that it was necessary and proper for Congress to prevent this 'dangerous' cohort of individuals from entering society."); Corey Rayburn Yung, Sex Offender Exceptionalism and Preventative Detention, 101 J. CRIM. L. \& CRIMINOLOGY 969, 996 (2011) ("[T]he majority opinion essentially rewrote law surrounding the Necessary and Proper Clause to allow for virtually unfettered federal power in the area of sex offender civil commitment.").

164 Cucolo \& Perlin, Media Distortions of Sex Offenders, supra note 163, at 238-39 (2013) ("[T]he majority accepted the fact that sexual predators pose a high risk of dangerousness and that future risk can be determined."). 
Supreme Court decisions such as Hendricks ${ }^{165}$ that support SVPAs - which, as one of the authors noted previously, "transform[] psychiatric treatment facilities into de facto prisons and that use[] mental

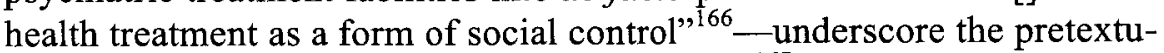
ality of the entire sex-offender legal apparatus. ${ }^{167}$ As one of the authors previously wrote with another colleague, "[t]here may be no area of mental disability law that is more pretextual than that governing the incapacitation of sex offenders." ${ }^{\text {168 }}$ Indeed, as one of the authors previously observed in a prior piece with another colleague, "[e]very newspaper article reporting that a sex offender was released into the community expresses the public misconception that there are reliable and valid ways to assess recidivism risk." 169 Heuristic "shortcuts" that are used by courts to manipulate the complexities of mental health law and social science in this area ${ }^{170}$ reflect the worst of both heuristic reasoning and "ordinary common sense." ${ }^{\prime 11}$ Our willful blindness to studies on treatment effect, future risk-assessment ability, recidivism, and prevention strategies reflect leg-

165 Kansas v. Hendricks, 521 U.S. 346 (1997).

166 Perlin, Exposing Pretextuality in Hendricks, supra note 39, at 1269-1270 ("Hendricks is a troubling opinion on at least eleven levels, and each level demonstrates its pretextuality. First, it indicates that a majority (albeit, a bare one) of the Supreme Court is comfortable with a statutory scheme that has the potential of transforming psychiatric treatment facilities into de facto prisons and that uses mental health treatment as a form of social control[.]"). On how social control efforts of the mental health system may "inadvertently contribute to violence" by some persons with mental disabilities, see Eric Silver, Understanding the Relationship Between Mental Disorder and Vialence: The Need for a Criminological Perspective, 30 LAw \& HUM. BEHAV. 685, 693-94 (2006).

167 On pretextuality, see supra note 37. Consider also how SVPAs in New York are applied. Even though SVPA cases are nominally characterized as civil proceedings, trials are held in the Criminal Division of the Supreme Court, have Criminal Division judges, and if a jury trial is elected, the juries comprise twelve jurors instead of six. See generally N.Y. MENTAL HYG. LAW art. 10 (2015); State v. Ted B., 15 N.Y.S.3d 366 (A.D. 2015).

168 Michael L. Perlin \& John Douard, "Equality, I Spoke That Word/As If a Wedding Vow": Mental Disability Law and How We Treat Marginalized Persons, 53 N.Y.L. SCH. L. REV. 9, 28 (200809) [hereinafter Perlin \& Douard, Treatment of Marginalized Persons]; see also, Heather Ellis Cucolo \& Michael L. Perlin, "The Strings in the Books Ain't Pulled and Persuaded": How the Use of Improper Statistics and Unverified Data Corrupts the Judicial Process in Sex Offender Cases, 69 CASE W. RES. L. REV. - (2019) (forthcoming).

169 Perlin \& Douard, Treatment of Marginalized Persons, supra note 157, at 20 ("Every time Detective Benson or Stabler-on NBC's popular Law and Order: SVU program-says, 'There's no cure. And they all do it again,' that speaks to society's ['ordinary common sense'] about this topic. Every newspaper article reporting that a sex offender was released into the community expresses the public misconception that there are reliable and valid ways to assess recidivism risk."); see also, e.g., Astrid Birgden, Therapeutic Jurisprudence and Sex Offenders: A Psycho-Legal Approach to Protection, 16 SEXUAL ABUSE: J. RES. \& TREATMENT 351, 353 (2004) [hereinafter Birgden, TJ and Sex Offenders]; see generally Cucolo \& Perlin, Media Distortions of Sex Offenders, supra note 163 (discussing how the media affects sex offender law and policy).

${ }_{170}$ Eric S. Janus, Toward a Conceptual Framework for Assessing Police Power Commitment Legislation: A Critique of Schopp's and Winick's Explications of Legal Mental Illness, 76 NEB. L. REV. 1, 37 n.146 (1997) ("It seems quite clear that courts operate heuristically in the mental health area. That is, they use 'shortcuts' to manipulate the complexities of mental health law and social science that underlies it.").

171 See Keri K. Gould \& Michael L. Perlin, "Johnny's in the Basement/Mixing Up His Medicine": Therapeutic Jurisprudence and Clinical Teaching, 24 SEATTLE U. L. REV. 339, 357 (2000) (ordinary common sense is "comprised of a prereflective attitude exemplified by the attitude of "What I know is self-evident'; it is 'what everybody knows." (internal citations and some internal quotations omitted)). 
islatures' and courts' succumbing to the vividness heuristic. ${ }^{172}$ In addition, consider what Professor John Douard has said in this context: "Sanism is as virulent as, but more rarely noticed than, racism and sexism; discrimination against [sex] offenders is virtually invisible, because their criminal conduct creates a pretext to isolate them as sources of contamination." 173 And, as one of the authors has previously noted, "[w]e are especially sanist when it comes to questions concerning the sexuality of persons with mental disabilities." 174

In short, the history of sex-offender law is of shaming behavior that reflects the worst of sanism and pretextuality, which as one of the authors has previously noted has been "abetted by heuristic reasoning and reliance on a false, alleged 'ordinary common sense." ${ }^{175}$ And much of this flows from the meretricious ways that cases such as Hendricks and its progeny have blithely blurred civil and criminal mental disability law. ${ }^{176}$ In the seventeen years since Professor Stephen Morse wrote that "[s] exual predators fall into the gap between criminal and civil confinement," 177 little, if anything, has changed.

These cases-in the aggregate-demonstrate that the Supreme Court is comfortable with this post-sentencing blur between criminal and civil mental disability law, and specifically that the Court is equally comfortable with pretextually characterizing what are clearly criminal penalties and conditions of confinement as civil so as to save them from constitutional challenge. ${ }^{178}$

172 For a discussion of the impact of vividness of mental disability law, see supra note 128.
J73 John Douard, Sex Offender as Scapegoat: The Monstrous Other Within, 53 N.Y.L. SCH. L.
REV. 31,38 (2008-09) (first emphasis added). See infra note 223 for an explanation of sanism.
See Perlin, Exposing Pretextuality in Hendricks, supra note 39 , at 1252 n.34; see also MICHAEL L. Perlin \& Alison J. Lynch, Sexuality, Disability and the LaW: Beyond the Last FronTIER? (2016) (discussing sanism towards persons with mental disabilities); Michael L. Perlin, Heather Ellis Cucolo, \& Alison J. Lynch, Sex, Sexuality, Sexual Offending and the Rights of Persons with Mental Disabilities, 6 LAws 20,3-4 (2017) (discussing society's attitudes towards sexuality and disabled persons); see generally Michael L. Perlin, "Limited in Sex, They Dare": Attitudes Toward Issues of Patient Sexuality, 26 AM. J. FORENSIC PSYCHIATRY 25 (2005) (same).

175 Michael L. Perlin, Myths, Realities, and the Political World: The Anthropology of Insanity Defense Attitudes, 24 BULL. AM. ACAD. PSYCHIATRY L. 5, 21 (1996). On the pretextuality "of the entire SVPA process," see Heather Ellis Cucolo \& Michael L. Perlin, "Far from the Turbulent Space": Considering the Adequacy of Counsel in the Representation of Individuals Accused of Being Sexually Violent Predators, 18 U. PA. J.L. \& SoC. CHANGE 125, 164 (2015).

176 See, e.g., Georgia Smith Hamilton, The Blurry Line Between "Mad" and "Bad": Is "Lack of Control" a Workable Standard for Sexually Violent Predators?, 36 U. RICH. L. REV. 481, 503-05 (2002) (discussing whether individuals with antisocial personality disorder fall within the scope of sexually violent predator laws).

177 Morse, supra note 40 , at 1027.

178 On how such decisions reflect a kind of "populist punitiveness," see Simon, supra note 29, 455-56. On penal populism in general, see Albert W. Dzur, Participatory Democracy and Criminal Justice, 6 CRIM. L. \& PHIL. 115, 116-17 (2012). 


\section{Imprisoning Insanity Acquittees. ${ }^{179}$}

In several states, insanity acquittees deemed criminally insane can be sent to prisons for "treatment" 180 instead of receiving treatment in psychiatric facilities. ${ }^{181}$ Insanity acquittees present an unusual case in that they have not been convicted of a crime and therefore cannot be punished. ${ }^{182}$ However, states are typically given wide discretion as to where to house dangerous acquittees as long as treatment is provided and the confinement is related to a legitimate goal. ${ }^{183}$

By way of example, since 2010 , the state of Washington has allowed for the transfer of someone deemed criminally insane to a correctional facility if the person presents an "unreasonable safety risk which, based on behavior, clinical history, and facility security is not managea-

179 This section is partially adapted from PERLIN \& CUCOLO, CIVIL AND CRIMINAL, supra note 6, $\S \S 5-2.2$ to 5-2.4.2, Perlin, Exposing Pretextuality in Hendricks, supra note 39, and PERLIN \& CuCOlo, DETRIMENTS OF SVP Legislation, supra note 27. See also Cucolo \& Perlin, Promoting Dignity for SVPs, supra note 127, 293-296 (discussing two Supreme Court cases and how they apply to Sexually Violent Predator Act cases); Cucolo \& Perlin, Preventing Sex-Offender Recidivism through TJ, supra note 127 , at $2-5$ (giving an overview of the kinds of laws applying to sex offenders).

180 We place "treatment" in quotes to underscore how minimal this right is. See Estelle v. Gamble, 429 U.S. 97, 104 (1976) (stating that "deliberate indifference" to healthcare needs creates a cause of action); Ruiz v. Estelle, 503 F. Supp. 1265, 1399 (S.D. Tex. 1980), modified in part, vacated in part, 688 F.2d 266 (5th Cir. 1982) (listing basic treatment criteria). On how only "minimal" standards must be met, see, for example, Paul Sario, Financing Mental Healthcare: A Budget-Saving Proposal for Rethinking and Revitalizing Florida's Involuntary Assisted Outpatient Treatment Law, 42 STETSON L. REV. 207, 218-20 (2012).

181 See, e.g., REV. CODE WASH. $\$ 10.77 .091$ (1) (2010) ("If the secretary determines in writing that a person committed to the custody of the secretary for treatment as criminally insane presents an unreasonable safety risk which, based on behavior, clinical history, and facility security is not manageable in a state hospital setting, and the secretary has given consideration to reasonable alternatives that would be effective to manage the behavior, the secretary may place the person in any secure facility operated by the secretary or the secretary of the department of corrections."); CAL. WELF. \& INST. $§ 7301$ (2012) ("Whenever, in the opinion of the Director of State Hospitals and with the approval of the Secretary of the Department of Corrections and Rehabilitation, any person who has been committed to a state hospital pursuant to provisions of the Penal Code ... needs care and treatment under conditions of custodial security which can be better provided within the Department of Corrections and Rehabilitation, the person may be transferred for those purposes from an institution under the jurisdiction of the State Department of State Hospitals to an institution under the jurisdiction of the Department of Corrections and Rehabilitation."); ARIZ. REV. STAT. ANN. § 13502(D) (2013) (implying that if someone found "guilty but insane" is no longer "insane," that person can be transferred to a prison to serve out the sentence); $c f$. State v. Bomar, 19 P.3d 613, 616 (Ariz. Ct. App. 2011) ("[A] finding of guilty-except-insane is not a criminal conviction.").

182 Kempner, supra note 34 , at $632 \& \mathrm{n} .52$ (noting that "[ $\mathrm{t}]$ he insanity acquittee has not been convicted of a crime," that "[h]e may not therefore be punished," and citing Jones, 463 U.S. at 369 n.18 as stating that "[s]ociety may not excuse a defendant's criminal behavior because of his insanity and at the same time punish him for invoking an insanity defense").

${ }_{183}$ See id. at 642 ("Due to limited resources, states often need to choose between creating additional space at secure, mental institutions and developing less costly community-based facilities. A State could place insanity acquittees in penal institutions if the confinement constituted a legitimate regulatory goal, where the primary goal is to protect society and the secondary goal is to provide treatment of illness. Where a state lacks appropriate secure facilities, placement of dangerous acquittees in a separate wing of a prison facility specifically staffed by the Department of Health for treatment purposes, may not be an excessive 'alternative purpose."'). 
ble in a state hospital setting." 184 Disability Rights Washington (DRW), a nonprofit organization that protects the rights of persons with disabilities throughout that state, subsequently filed a class-action federal lawsuit, G.R. ex rel. Moore v. Gregoire. ${ }^{185}$ Gregoire challenged the constitutionality of the statute based on procedural due process, equal protection, double jeopardy, ex post facto, the ADA, and the Rehabilitation Act. ${ }^{186}$ Although the lawsuit was eventually dismissed due to ancillary procedural issues (standing and ripeness) because no individual had yet been transferred, the Court did recognize the possibility that the law's legitimacy may fail upon a closer analysis of its actual implementation. ${ }^{187}$

Laws allowing for such transfers are problematic for many reasons. There is no question that treatment of persons with mental illness in prisons is often grossly inadequate; ${ }^{188}$ it thus makes no sense to remove insanity acquittees from hospitals into correctional facilities. As one of the authors have previously noted, correctional staff "often have no education or training in the appropriate treatment of detainees" or prisoners "with a mental illness"189 and "thus may respond with aggressive measures that ultimately exacerbate symptoms of [inmates'] conditions." ${ }^{190}$ It is therefore no surprise that a disproportionate number-an estimated thirty percent - of inmates in solitary confinement are mentally ill. ${ }^{191}$ As stated previously by some of the authors, "[s]uicide is the lead-

\footnotetext{
184 REV. CODE WASH. $\$ 10.77 .91(1)(2010)$.

185 G.R. ex rel. Moore v. Gregoire, No. CV-10-00088-EFS, 2010 WL 3222801 (E.D. Wash. Aug.
} $13,2010)$.

186 Amended Class Action Complaint for Injunctive and Declaratory Relief at 2-3, Gregoire, 2010 WL 3222801 (citing, inter alia, Americans with Disabilities Act, 42 U.S.C. $\S 12101-12213$ (2012) and the Rehabilitation Act, 29 U.S.C. \& 701-799 (2012)).

187 Order Granting Defendants' Motion to Dismiss, Entering Judgment, and Closing File at 4, Gregoire, 2010 WL 3222801 ("Section 2 [of the recently enacted Washington state law allowing for transfer] has a plainly legitimate sweep [based on Supreme Court precedent]. This plainly legitimate sweep may fail upon closer analysis after implementation but, at this juncture, the facial challenge fails. The Court finds the exercise of judicial restraint is necessary." (internal citations omitted)).

188 See, e.g., Jamie Fellner, A Conundrum for Corrections, A Tragedy for Prisoners: Prisons as Facilities for the Mentally Ill, 22 WASH. U. J.L. \& POL'Y 135, 137-140 (2006) ("In the most extreme cases conditions are truly horrific: mentally ill prisoners are locked in segregation with no treatment at all; confined in filthy and beastly hot cells; left for days covered in feces they have smeared over their bodies; taunted, abused, or ignored by prison staff; given so little water during summer heat waves that they drink from their toilet bowls. A prison expert described one prison unit holding many mentally ill prisoners as 'medieval . . cramped, unventilated, unsanitary . . . it will make some men mad and mad men madder.' Suicidal prisoners are left naked and unattended for days on end in barren, cold observation cells." (citations omitted)).

189 See id. at 139 ("Poorly trained correctional officers have accidentally asphyxiated mentally ill prisoners whom they were trying to restrain."); Henry A. Dlugacz \& Luna Droubi, The Reach and Limitation of the ADA and its Integration Mandate: Implications for the Successful Reentry of Individuals with Mental Disabilities in a Correctional Population, 35 BEHAV. SCI. \& L. 135, 139 (2017) [hereinafter Dlugacz \& Droubi] ("While causation [of a fourfold increase in U.S. prison population between 1980 and 2012] is a matter of fierce debate, large numbers of people with serious mental disabilities were swept up in this tsunami of incarceration. While incarcerated, many of these people received inadequate treatment and deficient, if any, reentry planning.").

190 Perlin \& Schriver, Reconsidering Forced Drugging Pre-Trial, supra note 13, at 396; see also Fellner, supra note 188, at 139 (noting incidents of accidental asphyxiation).

191 Perlin, Insanity Defense and Incompetency Status Required by CRPD \& TJ, supra note 6, at 508 (citing Jessica Knowles, "The Shameful Wall of Exclusion": How Solitary Confinement for In- 
ing cause of death in jails and prisons, and research suggests that the high suicide rates are correlated with untreated depression." 192

Prisons and jails "are often not properly equipped to handle persons with mental disabilities because they were never meant to function as mental health facilities." 193 They are "crippled by understaffing, insufficient facilities, limited programs, and restrictions imposed on them by prison rules and prison culture." 194 In many instances, prisoners with mental illness who refuse to comply with orders are often subject to physical force through "methods such as chemical sprays, electric shocks, and long term physical restraints." 195 Inmates with mental health conditions and certain social and cognitive impairments "are at a higher risk of being victims of violence and displaying more violent behavior relative to inmates without such disabilities." ${ }^{, 196}$ In addition, where there is an "absence of timely and effective reasonable accommodations, as well as the lack of effective communications and physical accessibility," it "significantly increases the likelihood of present and future injury and illness facing prisoners with disabilities."197 "The shame that these individuals experience as a result of the loss of their rights and liberties is rarely, if ever, discussed, even though it is readily acknowledged after

mates with Mental Illness Violates the Americans with Disabilities Act, 90 WASH. L. REV. 893, 90607 (2015), which notes that "[i]t is estimated that around thirty percent of the inmates in solitary are mentally ill. This high percentage is due both to the disproportionate number of mentally ill inmates who are placed in disciplinary and administrative segregation, as well as the negative psychological impact of isolation. Additionally, this negative psychological impact makes it difficult for inmates to comply with the requirements that would allow them to 'earn' their way out of isolation." (internal citations omitted)).

192 Weinstein \& Perlin, Cycle Deprives Continuity of Care, supra note 35, at 264 (citing Kanya D'Almeida, In US Prisons, Psychiatric Disability is Often Met by Brute Force, TRUTHOUT (July 18, 2015), http://www.truth-out.org/news/item/31886-in-us-prisons-psychiatric-disability-is-often-metby-brute-force\# [https://perma.cc/AC75-UQJK] (noting that according to a state survey conducted by nonprofit Treatment Advocacy Center, "half of all prisoner suicides are committed by people who are seriously mental ill") and Nicholas Freudenberg, Jails, Prisons, and the Health of Urban Populations: A Review of the Impact of the Correctional System on Community Health, 78 J. URB. HEALTH: BULL. N.Y. ACAD. MED. 214, 221 (2001) (noting that "[s]uicide is the leading cause of death in jails and prisons" and observing generally that "[r]esearchers suggest that high suicide rates in correctional facilities are associated with high rates of untreated depression").

${ }^{193}$ Id. at 468 (quoting Fellner, supra note 188, at 136, which notes that "[p]risons were never intended to function as mental health facilities. The growing number of mentally ill persons who are incarcerated in the United States is an unintended consequence of two distinct public policies that have prevailed over the last thirty years").

194 Id. at 468 (quoting Fellner, supra note 188, at 137).

195 Id. at 467 (quoting Destiny Howell, The Unintended Consequences of Deinstitutionalization, 54 AM. CRIM. L. REV. ONLINE 17, 21 (2017), available at $\mathrm{http} / /$ www.americancriminallawreview.com/files/7214/8856/2214/Howell_Deinstitutionalization.pd f.

196 Id. at 468 (quoting Peter Blanck, Disability in Prison, 26 S. CAL. INTERDISC. L.J. 309, 314 (2017), which states therein after "[i]nmates with comorbid mental health conditions, and psychosocial and cognitive impairments (who are overrepresented in prisons) are at a higher risk of being victims of violence and displaying more violent behaviors relative to inmates without such disabilities" (internal citations omitted)).

197 Id. at 468 (quoting Blanck, supra note 196, at 314, which states therein that "[a]bsent reasonable accommodations, for instance, inmates with disabilities are less able to engage meaningfully in prison activities as offered to the general population, and they are more vulnerable to misunderstanding and exploitation by other prisoners and correctional staff."). 


\author{
the fact by individuals who have faced these circumstances."198
}

\title{
D. Continuity of Care. ${ }^{199}$
}

Continuity of care ${ }^{200}$ includes treatment while incarcerated as well as treatment upon reentry. ${ }^{201}$ The cycle of shuttling between hospitals, incarceration, and the community can impede proper continuity of care. ${ }^{202}$ Over thirty years ago, the late Professor Bruce Winick called our

198 Id. at 468-69; see also Cucolo \& Perlin, Promoting Dignity for SVPs, supra note 127, at 296302 ("It is no surprise that the vast majority of sex offenders self-report being humiliated on a daily basis."); Michael L. Perlin \& Alison J. Lynch, "She's Nobody's Child/The Law Can't Touch Her at All": Seeking to Bring Dignity to Legal Proceedings Involving Juveniles, 56 FAM. CT. REV. 79, 88 (2018) ("Our treatment of juveniles - in the civil commitment process, in all aspects of juvenile delinquency cases, in waiver proceedings, and in institutional settings-shames and humiliates them, robs them of their dignity, and violates the essence of [therapeutic justice]."); Michael L. Perlin \& Alison J. Lynch, "To Wander Off in Shame": Deconstructing the Shaming and Shameful Arrest Policies of Urban Police Departments in Their Treatment of Persons with Mental Disabilities, in SYSTEMIC HUMILIATION IN AMERICA: FINDING DIGNITY WITHIN SYSTEMS OF DEGRADATION 175 (Prof. Daniel Rothbart ed., 2018) [hereinafter Perlin \& Lynch, Shameful Arrests].

199 This section is partially adapted from PERLIN \& CUCOLO, CIVIL AND CRIMINAL, supra note 6, $\S \S 5-2.2$, to 5-2.4.2, Perlin, Exposing Pretextuality in Hendricks, supra note 39, and PERLIN \& CUCOLO, DETRIMENTS OF SVP LEGISLATION, supra note 27. See also Cucolo \& Perlin, Preventing Sex-Offender Recidivism through TJ, supra note 127, at $2-5$ (giving an overview of the kinds of laws applying to sex offenders); Heather Ellis Cucolo \& Michael L. Perlin, Promoting Dignity and Preventing Shame and Humiliation by Improving the Quality and Education of Attorneys in Sexually Violent Predator (SVP) Civil Commitment Cases, 28 FLA. J.L. \& PUB. POL'Y 291, 293-296 (2017) [hereinafter Cucolo \& Perlin, Promoting Dignity for SVPS] (discussing two Supreme Court cases and how they apply to Sexually Violent Predator Act cases).

200 By the phrase "continuity of care," we adopt the definition offered by Bruce Frederick: "1) continuity of control, 2) continuity in the range of services, 3) continuity in service and program content, 4) continuity of social environment, and 5) continuity of attachment." Weinstein \& Perlin, $C y$ cle Deprives Continuity of Care, supra note 35, at 457. David M. Altschuler \& Troy L. Armstrong, Juvenile Corrections and Continuity of Care in a Community Context-The Evidence and Promising Directions, 66 FED. PROBATION 72, 73 (2002) (quoting BRUCE FREDERICK, FACTORS CONTRIBUTING TO RECIDIVISM AMONG YOUTH WITH THE NEW YORK STATE DIVISION FOR YOUTH $20-21$ (1999), available

http://www.criminaljustice.ny.gov/crimnet/ojsa/dfy/dfy_research_report.pdf). Beyond this, continuity of care also requires "effective interagency and provider communication to share information, facilitate access, and integrate care across providers and settings" and the "development of caring, respectful relationships with caregivers so that needs are identified and consumers are engaged in care." Rebecca Spain Broches, Creating Continuity: Improving the Quality of Mental Health Care Provided to Justice-Involved New Yorkers, 21 GEO. J. ON POVERTY L. \& POL'Y 91, 100 (2013) (quoting Janet Durbin et al., Continuity of Care: Validation of a New Self-Report Measure for Individuals Using Mental Health Services, 31 J. BEHAV. HEALTH SERVS. \& RES. 279, 280 (2004).

${ }^{201}$ See Weinstein \& Perlin, Cycle Deprives Continuity of Care, supra note 35, at 460 (citing Dlugacz \& Droubi, supra note 187 , at 139 , to state that "the concept of continuity of care includes continuity of control, of services, of program content, of social environment, and of attachment. It requires re-entry preparation, the creation of community linkages, and insurance that the required services will be delivered. There is no question that the lack of continuity of mental health services severely impairs the ability of community-based mental health providers to have any therapeutic impact on this population. Henry Dlugacz and Luna Droubi state the problem succinctly: "While incarcerated, many of these people received inadequate treatment and deficient, if any, reentry planning. Once released to the community, many received insufficient support and subsequently were incarcerated." ).

${ }^{202}$ See Shauhin Talesh, Mental Health Court Judges as Dynamic Risk Managers. A New Concep- 
attention to "the well-known chain of events [involving criminal defendants with mental disabilities] from incompetency determination to hospital to stabilization to return to jail to decompensation to re-determination of incompetency to re-hospitalization several times, means that some individuals are well known subjects of repeated forensic evaluations.",203 As Winick noted and one of the authors continued to observe nineteen years ago, psychiatric hospital commitments of this population "are frequently followed by a 'shuttle process' by which defendants are stabilized, returned to jail to await trial, and returned to the hospital following relapse." 204 Over a decade ago, a trial judge in Vermont succinctly outlined the problem as it extends to reentry:

Discharge into the community without planning or supervision is likely to result in a repetition of the cycle of violent offense, incarceration, overt signs of mental illness in jail, commitment, and reduced or largely absent signs of mental illness in the hospital which has marked [the defendant's] adult life. $^{205}$

And in 2017, former President Barack Obama cited studies noting the existence of "a relatively small number of highly vulnerable individuals [who] cycle repeatedly not just through local jails, but also hospital emergency rooms, shelters, and other public systems."206

In short, this is a problem, as some of the authors previously acknowledged, that "has not gone away, and is one that any of us who take seriously the entire bundle of issues that are raised by this phenomenon-how we treat this population; how we fail to learn from our history of failure; how we ignore options that might potentially ameliorate the underlying situation; how we demand quick fixes, and ignore the "long game'-must take equally seriously": "the way we criminalize behavior that disproportionally affects people with mental illness.",207

tualization of the Role of Judges, 57 DEPAUL L. REV. 93, 101-02 (2007) (emphasizing how prisoners cycle in and out of the criminal justice system and rarely receive hospital treatment while incarcerated).

${ }^{203}$ Bruce J. Winick, Restructuring Competency to Stand Trial, 32 UCLA L. REV. 921,934 n.52 (1985) [hereinafter Winick, Restructuring Competency to Stand Trial] (emphasis omitted) (quoting E. Nuehring, L. RAYBIN, A. PASCONE, E. Fritsche \& S. GRAY, A PlanNing AND NeEdS StUdy IN THE AREA OF COMMUNITY PROGRAMMING FOR FORENSIC MENTAL HEALTH CliENTS 37-39 (unpublished report submitted to the Dade-Monroe [Florida] Mental Health Board in 1984)).

204 Perlin, ADA Impact on Criminal Defendant Institutionalization, supra note 6, at 204 n.76 (citing Winick, Restructuring Competency to Stand Trial, supra note 201, at 934, which notes that "[d]efendants commonly spend six months or more shuttling between court and hospital until the court finally is satisfied that they have been restored to competency").

205 State v. Swift, Nos. 1191-8-00 Wncr, 175-5-04 Oecr, 2006 WL 2627322 (Vt. Dist. Ct. Mar. 24, 2006).

206 Barack Obama, The President's Role in Advancing Criminal Justice Reform, 130 HARV. L. REV. 811, 848 (2017) (quoting Press Release, Office of the Press Sec'y, FACT SHEET: Launching The Data-Driven Justice Initiative: Disrupting The Cycle Of Incarceration (June 30, 2016), https://www.whitehouse.gov/the-press-office/2016/06/30/fact-sheet-launching-data-driven-justiceinitiative-disnupting-cycle [https://perma.cc/55E3-RYHR].

${ }^{207}$ Weinstein \& Perlin, Cycle Deprives Continuity of Care, supra note 35, at 456. See, e.g., Mi- 
This cycle of shuttling is negative for many reasons, "not least of which is the way that it deprives the cohort of individuals at risk from any meaningful continuity of care and how it exacerbates the problems caused by the unnecessary and counterproductive arrests of persons with mental disabilities for 'nuisance' crimes." ${ }^{208}$ Without continuity of care, "it is far less likely that any therapeutic intervention will have any longlasting ameliorative effect," and in some cases, state process may actively thwart authentic continuity-of-care efforts. ${ }^{209}$ Involvement of persons with mental illness in both the mental health system and the criminal justice system can also lead to a double social stigmatism, ${ }^{210}$ which can additionally impede therapy. The authors believe that our current system is "utterly counter-productive (and in many ways, destructive)" and further fails miserably to meet any of these prescriptive standards. ${ }^{211}$

Ironically, it is relatively clear that some things can be done to provide the needed continuity of care for persons with mental disabilities enmeshed in the "shuttle system" between jails or prisons, hospitals, and the street. The right to continuity of care is supported by principles of therapeutic jurisprudence and, as the authors contend, is "guaranteed under both domestic and international law." 212 If provided to those with mental illness, it "can lead to better protection of medical information. "213 Continuity of care can be improved through interventions

chael L. Perlin, "Wisdom Is Thrown into Jail": Using Therapeutic Jurisprudence to Remediate the Criminalization of Persons with Mental Illness, 17 MiCH. ST. J. MED. \& LAW 343, 350-353 (2013) [hereinafter Perlin, Using TJ to Remediate Criminalization] (noting, "most importantly of all, that ' $[t]$ here is no evidence for the basic criminalization premise that decreased psychiatric services explain the disproportionate risk of incarceration for individuals with mental illness,' that 'there is little evidence that the risk of incarceration has uniquely increased for those with mental illness,' and that 'no research exists demonstrating that mental illness is a principal or proximate cause of criminal behavior for most offenders with mental illnesses."' (internal citations omitted)).

208 Weinstein \& Perlin, Cycle Deprives Continuity of Care, supra note 35, at 456; see generally Perlin \& Lynch, TJ Perspective on Interactions with Police, supra note 19; Perlin \& Lynch, Shameful Arrests, supra note 198.

209 Id. at 456; see, e.g., N.Y. MENTAL HYG. LAW $\$ 9.27$ (2015) (referencing the transfer of some of these shuttled individuals to state hospitals via what is known as the "two PC" method of commitment, based on "[i]nvoluntary admission on medical certification"); State of New York ex rel. Green v. Superintendent of Sullivan Corr. Facility, 25 N.Y.S.3d 375, 376 (2016) (noting the retention of persons in prisons after their conditional release dates in residential treatment facilities).

${ }^{210}$ See Michael L. Perlin \& Alison Lynch, "Toiling in the Danger and in the Morals of Despair". Risk, Security, Danger, the Constitution, and the Clinician's Dilemma, 5 IND. J. L. \& SoC. EQUALITY 409, 410 (2017) ("Given their involvement with the criminal justice system and the mental health system simultaneously, this population has always been doubly stigmatized."); Michael L. Perlin, On "Sanism", 46 SMU L. REV. 373, 398-99 (1992) [hereinafter Perlin, On "Sanism"] (quoting, in part, Ellen Hochstedler, Twice-Cursed? The Mentally Disordered Criminal Defendant, 14 CRIM. JUST. \& BEHAV. 251 (1987)).

211 Weinstein \& Perlin, Cycle Deprives Continuity of Care, supra note 35, at 458. We believe the current system is also "violative of the constitutional right to treatment and the statutory right to nondiscrimination as provided in human rights law both domestically (the Americans with Disabilities Act) ('ADA') and internationally (the Convention on the Rights of Persons with Disabilities) ('CRPD')." Id. at 458. As we noted above, see supra note 49, we will be focusing on this issue in a subsequent article.

212 See infra Part VI (discussing therapeutic jurisprudence); Weinstein \& Perlin, Cycle Deprives Continuity of Care, supra note 35 , at 501

${ }^{213}$ Weinstein \& Perlin, Cycle Deprives Continuity of Care, supra note 35, at 501; see also, e.g., 
such as "[mental health courts], diversion practices, [and] mental health screening[.]"214 Accommodations for treatment can also be made for defendants deemed incompetent to stand trial. ${ }^{215}$ Further, "better training for corrections employees, court personnel, lawyers, judges, and police officers" is essential, as there is valid and reliable evidence that such training will lead to better therapeutic outcomes. ${ }^{216}$ Implementing these strategies will remediate the problems caused by the blur in this area of law and social policy.

\section{THE IMPLICATIONS OF BLURRING.}

What are the broader implications of these blurs for all of mental disability law? Laws and decisions blurring the borderline between criminal and civil disability law import aspects of criminalization upon civil institutionalization and simultaneously cast schemes as "civil" that are profoundly criminal. One broader implication is that these laws and decisions substantially widen the net of involuntary civil commitment. ${ }^{217}$

For another implication, consider the different weights courts give expert psychiatric testimony by state psychiatrists in civil commitment cases as compared to that given by defense experts in insanity defense cases. In part due to relatively recent neoconservative reforms to laws governing the insanity defense and civil commitment, judges "value psychiatric expertise when it contributes to the social-control functions of law and disparage it when it does not." ${ }^{218}$ In civil commitment cases,

Broches, supra note 200 , at 106 ("While mental health information should not be readily disclosed, properly designed information sharing systems can provide sufficient protection for patient privacy. One way to address privacy concerns is to emphasize patient consent for information sharing. Given that confidentiality and privacy are important values in health care, obtaining consent is a way to demonstrate respect for the individual's autonomy, even where it is not legally required.").

214 Weinstein \& Perlin, Cycle Deprives Continuity of Care, supra note 35, at 501; see also infra text accompanying notes $224-42$ (discussing mental health courts generally).

215 See, e.g., Perlin, ADA Impact on Criminal Defendant Institutionalization, supra note 6, at 205 (discussing accommodations made by some states).

216 Weinstein \& Perlin, Cycle Deprives Continuity of Care, supra note 35, at 501; see generally Perlin \& Lynch, TJ Perspective on Interactions with Police, supra note 19 (discussing a therapeuticjurisprudence approach to interactions between police and persons with mental disabilities).

217 See, e.g., Michael L. Perlin, Competency, Deinstitutionalization, and Homelessness: A Story of Marginalization, 28 Hous. L. REV. 63, 124-25 (1991) (noting proposed legislation that would address the "deinstitutionalization-homelessness conundrum"); see also id. at $125 \mathrm{n} .170 ; 131 \mathrm{n} .396$ (citing In re S.L., 94 N.J. 128, 133-34 (1983), which noted therein that "[t]o widen the net cast by the civil commitment process . . . is inconsistent with the central purposes of the commitment process. It would permit the State to commit individuals to mental institutions solely to provide custodial care. This authority cannot be justified as a measure to safeguard the citizenry under the police power. Nor is it a proper exercise of the State's parens patriae power because confinement in a mental hospital is not necessary to provide the care needed by individuals who are simply incapable of living independently.").

218 See JOHN Q. LAFOND \& MARY L. DURHAM, BACK TO THE ASYLUM: THE FUTURE OF MENTAL HEALTH LAW AND POLICY IN THE UNITED STATES 156 (1992) (discussing how "[n]eoconservative insanity defense and civil commitment reforms value psychiatric expertise when it contributes to the social control function of law and disparage it when it does not."). 
psychiatrists "are more confidently seen as therapeutic helpers who get patients 'on the hook' of treatment and control.",219 But in insanity defense cases, these psychiatrists are "viewed skeptically as accomplices of defense lawyers who get criminals 'off the hook' of responsibility." 220 As one of the authors previously noted regarding the use of empirical research to justify treatment in mental disability law, "we tend to ignore, subordinate or trivialize [certain other] behavioral research in this area, especially when acknowledging that such research would be cognitively dissonant with our intuitive - albeit empirically flawed-views." ${ }^{221}$ This tendency may also extend to how judges vary their view of psychiatrists depending on the type of proceeding. ${ }^{22}$

Sanism ${ }^{223}$ and pretextuality-abetted by the use of the vividness heuristic and false "ordinary common sense"-permeate the entire mental disability law system. If we do not acknowledge their presence and their power, our attempts at understanding what really happens in this process can never succeed. As we blur the borderlines between criminal and civil mental disability law, the chances for any sort of meaningful understanding diminish.

\section{AREAS OF "POSITIVE" BLURRING.}

As we discussed in the introductory section, this is not to say that

219 Id.; see also Michael L. Perlin, Back to the Past: Why Mental Disability Law "Reforms" Don't Reform, 4 CRIM. L.F. 403, 410 (1993) (discussing implications of this discontinuity and reviewing LAFOND \& DURHAM, supra note 218 ).

220 Id.

221 Michael L. Perlin, A Law of Healing, 68 U. CIN. L. REV. 407, 422 (2000) ("These conflicts [in logic] compel an inquiry into the extent to which social science data does, or should, inform the development of mental disability law jurisprudence. After all, if we agree that mentally disabled individuals can be treated differently because of their mental disability, or because of behavioral characteristics that flow from that disability, it would appear logical that this difference in legal treatment is - or should be-founded on some sort of empirical data base that confirms both the existence and the causal role of such difference. Yet, we tend to ignore, subordinate or trivialize behavioral research in this area, especially when acknowledging that such research would be cognitively dissonant with our intuitive-albeit empirically flawed-views.").

222 See generally Michael L. Perlin, "I've Got My Mind Made Up:" How Judicial Teleology in Cases Involving Biologically Based Evidence Violates Therapeutic Jurisprudence, 24 CARDOzO J. EQUAL RTS. \& SOC. JUST. 81, 81 (2018) ("Courts are, and have always been, teleological in cases involving litigants with mental disabilities. By 'teleological,' I refer to outcome-determinative reasoning; social science that enables judges to satisfy predetermined positions is privileged, while data that would require judges to question such ends are rejected. Courts do this in cases involving, inter alia, the death penalty, the insanity defense, civil competency, incompetency to stand trial, questions related to malingering, juvenile criminal procedure, and criminal sentencing." (citations omitted)).

${ }^{223}$ Perlin, On "Sanism", supra note 210, at 374 ("[The examples of certain acts] reflect, rather, an irrational prejudice, an 'ism,' of the same quality and character of other prevailing prejudices such as racism, sexism, heterosexism and ethnic bigotry that have been reflected both in our legal system and in the ways that lawyers represent clients. This prejudice, which I will call 'sanism,' similarly infects both our jurisprudence and our lawyering practices."); see also MICHAEL L. PERLIN, THE HIDDEN PREJUdice: MENTAL Disability ON TRIAL 21-58 (2000) [hereinafter PERLIN, HidDEN PREJUDICE \& MENTAL DISABILITY] 
all blurring between civil and criminal mental disability law is necessarily negative. In this section, we will discuss positive blurs including those occurring with mental health courts and the ADA.

\section{A. Mental Health Courts. ${ }^{224}$}

Regarding treatment of criminal defendants with mental disabilities, there is no question that one of the most important developments in the past two decades has been the creation and the expansion of mental health courts as "[p]roblem-solving courts,",225 the significance of which grows as we begin to comprehend how persons with mental disabilities are disproportionately arrested for nuisance crimes. ${ }^{226}$ There is a wide range of dispositional alternatives in these $\operatorname{cases}^{227}$ and an even wider range of judicial attitudes. ${ }^{228}$ And the entire concept of "mental health courts" is certainly not without controversy. ${ }^{229}$

224 This section is generally adapted from Perlin, Difference of MHCs, supra note 42.

${ }_{225}$ See, e.g., Greg Berman \& John Feinblatt, Problem-Solving Courts: A Brief Primer, 23 LAW \& POL'Y, 125, 127 (2001) ("The past decade has been a fertile one for court reform. All across the country, courts - in concert with both government and community partners-have been experimenting with new ways to deliver justice. This wave of innovation goes by many names and takes many forms: Domestic violence court in Massachusetts; drug court in Florida; mental health court in Washington; community court in New York. Each of these specialized courts targets different kinds of concerns in different kinds of places. And yet they all share a basic organizing theme: a desire to improve the results that courts achieve for victims, litigants, defendants, and communities. 'Problemsolving courts' are still very much a work in progress.”); see also Greg Berman \& Aubrey Fox, The Future of Problem-Solving Justice: An International Perspective, 10 U. MD. L.J. RACE, RELIGION, GENDER \& ClASS 1, 3 (2010); Ursula Castellano, The Politics of Benchcraft: The Role of Judges in Mental Health Courts, 42 L. \& Soc'L INQUIRY 398, 398 (2017) [hereinafter Castellano, Judges in $M H C s]$ (examining the role of judges in problem-solving courts); see generally Edgely, supra note 48.

${ }^{226}$ See, e.g., Gerald E. Nora, Prosecutor As "Nurse Ratched"? Misusing Criminal Justice as Alternative Medicine, 22 CRIM. JUST. 18, 22 (2007) ("Most . . . defendants have been 'nuisance' offenders who have a high incidence of drug co-morbidity, treatment plan noncompliance, and recidivism. Their high recidivism rate and the problem of severe jail overcrowding made the mental health court experiment especially attractive to some county policy makers."). On the lack of continuity of care in such cases, see infra Part II.D.

${ }^{227}$ See, e.g., Henry J. Steadman et al., From Referral to Disposition: Case Processing in Seven Mental Health Courts, 23 BEHAV. SCI. \& L. 215, 220-222 (2005) (noting that, of the disposition alternatives, courts may accept or reject referred cases, that defendants themselves may opt out, and that it was possible that a decision not be made "because the referred person had been let out of jail on "time served").

${ }^{228}$ See, e.g., Michael S. King, Should Problem-Solving Courts Be Solution-Focused Courts?, 80 REV. JUR. U. P.R. 1005, 1006-09 (2011) ("In drug courts where participant involvement in decisionmaking is recognized it is generally as a subsidiary practice depending on the attitude of the individual judicial officer and other court personnel.").

${ }^{229}$ See, e.g., Tammy Seltzer, A Misguided Attempt to Address the Criminal Justice System's Unfair Treatment of People with Mental Illness, 11 PSYCHOL. PUB. POL'Y \& L. 570, 575 (2005) (“As a practical matter, mental health courts provide a form of pretrial diversion, most likely at or soon after the arraignment stage. A defendant who accepts transfer into a mental health court will be effectively waiving the right to a trial. It is the court's responsibility to ensure that the waiver of such a basic right is both voluntary and chosen with a realistic understanding of the legal consequences of the decision. The most reliable way to ensure that the waiver is both voluntary and informed is to provide defense counsel as soon as the defendant is identified as a candidate for the mental health court. .. . Defense attorneys should have at their disposal trained clinicians who work solely for the 
There is no question, however, that these mental health courts offer a new approach - perhaps a radically new approach - to the problems at hand. ${ }^{230}$ They become even more significant because of their promotion of dignity, ${ }^{231}$ as well as their embrace of therapeutic jurisprudence, their focus on procedural justice, and their use of the principles of restorative justice. ${ }^{232}$ It is time to restructure the dialogue about mental health courts and to begin to take seriously the potential ameliorative impact of such courts on the ultimate disposition of all cases involving criminal defendants with mental disabilities.

As one of the authors has previously noted, "[m]ental health courts are premised on team approaches. ${ }^{, 233}$ This approach involves many par-

defense to assess offenders at the time of the bail hearing to determine whether they should be considered for the mental health court."); Johnston \& Flynn, supra note 44, at 693 (reporting a recentand sobering-empirical critique of such courts based on negative mental health court data from one Pennsylvania county).

230 Some jurisdictions are beginning to seek out other alternative and complementary solutions to these issues. For recently-passed New York City local laws addressing the issue of mental health in the criminal system, see Arrestee Health Screenings and the Exchange of Health Information of Inmates in the Custody of the Department of Correction, N.Y. CITY CouNCIL (Oct. 18, 2016), http://legistar.council.nyc.gov/LegislationDetail.aspx?ID=2735148\&GUID=44E35DA3-1843-445695B6-511D0FF7EFB7 [https://perma.cc/E4JN-8UHG]; Requiring the Use of Trauma-Informed Care in City Correctional Facilities, N.Y. CITY COUNCIL (Oct. 18, 2016), https://legistar.council.nyc.gov/LegislationDetail.aspx?ID=2683868\&GUID=50FF659A-5D1142BC-A364-C15155C237CC [https://perma.cc/3YF7-ZKZF]; see generally Weinstein \& Perlin, Cycle Deprives Continuity of Care, supra note 35 (discussing how the law has "the capacity to allow for, encourage, or (in some cases) remediate humiliation, or humiliating or shaming behavior'); Perlin \& Lynch, TJ Perspective on Interactions with Police, supra note 19 (arguing for "options and opportunities for individuals in crisis that will empower them, rather than relegat[ing] them to the nation's largest mental health facilities"). For other new and innovative options being pursued in New York City, see generally THRIVENYC, A ROADMAP FOR MENTAL HEALTH FOR ALL (2018), https://thrivenyc.cityofnewyork.us/wp-content/uploads/2018/02/ThriveNYC-3.pdf

[https://perma.cc/Q8PM-XJQW].

${ }_{231}$ See Ginger Lerner-Wren, Mental Health Courts: Serving Justice and Promoting Recovery, 19 ANNALS HEALTH L. 577, 593 (2010) ("Furthermore, the guiding principles and values articulated in the United Nations Convention on the Rights of Persons with Disabilities should be implemented and fully integrated into every mental health court process in order to ensure the promotion of dignity, civil rights and human rights.").

${ }_{232}$ See generally Jessica Burns, A Restorative Justice Model for Mental Health Courts, 23 S. CAL. REV. L. \& SOC. JUST. 427 (2014) (discussing restorative justice); see also Thomas L. Hafemeister, Sharon G. Garner \& Veronica E. Bath, Forging Links and Renewing Ties: Applying the Principles of Restorative and Procedural Justice to Better Respond to Criminal Offenders with a Mental Disorder, 60 BUFF. L. REV. 147, 201-02 (2012) (discussing procedural justice); MiCHAEL L. PERLIN, A PRESCRIPTION FOR DIGNITY: RETHINKING CRIMINAL JUSTICE AND MENTAL DISABILITY LAW 88-96 (2013) [hereinafter PERLIN, RETHINKING CRIMINAL JUSTICE AND MENTAL DISABILITY LAW] (discussing restorative justice); Henry J. Steadman et al., Mental Health Courts: Their Promise and Unanswered Questions, 52 L. \& PSYCHIATRY 457, 457-58 (2001) (discussing therapeutic jurisprudence). On the relationship between these three approaches to justice, see PERLIN, RETHINKING CRIMINAL JUSTICE AND MENTAL DISABILITY LAW, supra note 232, at 96-98; Michael L. Perlin, Considering the "Alternative Jurisprudences" as a Tool of Social Change to Reduce Humiliation and Uphold Dignity (2012), http://www.humiliationstudies.org/documents/PerlinNY12AlternativeJurisprudences.pdf [https://perma.cc/GD96-FYXE].

233 PERLIN, RethINkING CRIMINAL JUSTICE AND MENTAL DiSABILITY LAw, supra note 232, at 71; see also, e.g., Arthur J. Lurigio \& Jessica Snowden, Putting Therapeutic Jurisprudence into Practice: The Growth, Operations, and Effectiveness of Mental Health Court, 30 JUST. SYS. J. 196, 210-11 (2009) ("So far, the operational history of [mental health court]s demonstrates that they function best when using a team approach for brokering treatment and other services for [people 
ticipants:

[R]epresentatives from justice and treatment agencies assist the judge in screening offenders to determine whether they would present a risk of violence if released to the community, in devising appropriate treatment plans, and in supervising and monitoring the individual's performance in treatment. The mental health court judge functions as part of a mental health team that decides whether the individual has treatment needs and can be safely released to the community. The team formulates a treatment plan, and a court-employed case manager and court monitor track the individual's participation in the treatment program and submit periodic reports to the judge concerning his or her progress. Participants are required to report to the court periodically so that the judge can monitor treatment compliance, and additional status review hearings are held on an as-needed basis. ${ }^{234}$

The turn to specialized mental health courts has much promise in the context of the problems we are addressing in this article. ${ }^{235}$ Mental health courts, like other problem-solving courts, "can use the power and authority of the judiciary to change the behavior of litigants and even, in some cases, the behavior of governmental systems." 236 They identify of-

with serious mental illnesses."); Marlee E. Moore \& Virginia A. Hiday, Mental Health Court Outcomes: A Comparison of Re-arrest and Re-arrest Severity Between Mental Health Court and Traditional Court Participants, 30 L. \& HUM. BEHAV. 659, 660 (2006) ("Mental health courts, one such diversion program, are modeled on drug courts having... [among other things] a nonadversarial team approach which involves joint decision-making between criminal justice and mental health professionals[.]"). On variances in team approaches, see generally Sheryl Kubiak, Liz Tillander \& Bradley Ray, Assessing the Role of Legal Actors Across Eight Mental Health Courts, 17 MicH. ST. U. J. MED. \& L. 301, 304-07 (2013) (discussing how mental health courts differ within each locality).

${ }^{234}$ Winick, Outpatient Commitment TJ Analysis, supra note 115, at 125-26. On the role of jail as a potential sanction in the cases of non-compliant defendants, see Allison Redlich et al., Patterns of Practice in Mental Health Courts: A National Survey, 30 LAW \& HUM. BEHAV. 347, 355-56 (2006) (surveying all mental health courts in the United States). On the role of a mental health court judge, see URsula CASTEllano, OUTSOURCING JusticE: THE Role OF NONPROFIT CASEWORKERS IN PRETRIAL RELEASE PROGRAMS 9 (2011) [hereinafter CASTELLANO, ROLE OF NONPROFIT CASEWORKERS IN PRETRIAL RELEASE] (describing the how caseworkers, in other contexts, "transform traditional courtroom justice"); Ursula Castellano, Courting Compliance: Case Managers as "Double Agents" in the Mental Health Court, 36 L. \& SoC. INQUIRY 484, 490-91(2011) [hereinafter Castellano, Case Managers in MHCs] (describing the often-conflicting roles of case managers in mental health courts). On the role of treatment plans, see J. Steven Lamberti, Preventing Criminal Recidivism Through Mental Health and Criminal Justice Collaboration, 67 PSYCHIATRIC SERV. 1206 (2016) (articulating strategies to optimize criminal justice-treatment collaborations); McDaniel M. Kelly, Rehabilitation Through Empowerment: Adopting the Consumer-Participation Model for Treatment Planning in Mental Health Courts, 66 CASE W. RES. L. REV. 581, 584 (2015) (explaining how the adoption of a consumer-participation model in mental health courts can "improve mental health court participants' capacity for voluntary participation").

235 See PERLIN \& CUCOLO, CIVIL AND CRIMINAL, supra note 6, $§ 1-2.2 .3$ (discussing the Broward County Court in Florida, presided over by Judge Ginger Lerner-Wren, which we believe is "by far, the most important" of such courts); Debra Baker, Special Treatment: A One-of-a-Kind Court May Offer the Best Hope for Steering Nonviolent Mentally Ill Defendants into Care Instead of Jail, 84 A.B.A. J., June 1998, at 20 (describing Judge Lerner-Wren's court).

${ }^{236}$ Derek A. Denckla, Forgiveness as a Problem-Solving Tool in the Courts: A Brief Response to 
fenders with mental illness and "order or sentence them to receive mental health services in lieu of confinement in a jail or prison.",237

These specialized mental health courts offer alternative management of criminal defendants with mental illnesses. ${ }^{238}$ Cases in these mental health courts benefit from improved processing time, improved access to mental health services, and reduced rates of recidivism relative to other courts. By way of examples, participants in such courts had significantly lower arrest rates after enrollment than before enrollment and lower post-enrollment arrest rates than comparison groups; in fact, they were more successful at reducing recidivism than were drug courtsstudies show that recidivism rates participants in mental health courts were twenty-five percent versus ten to fifteen percent. ${ }^{239}$ Mental health courts have also been shown to have positive effects on rehabilitation and recovery, which may contribute to lower recidivism rates. ${ }^{240}$

the Panel on Forgiveness in Criminal Law, 27 FORDHAM URB. L.J. 1613, 1614 (2000). ("These 'problem-solving' courts include drug courts, community courts, family treatment courts, mental health courts and gun courts.").

${ }^{237}$ Mark Heyrman, Mental Illness in Prisons and Jails, 7 U. CHI. L. SCH. RoundTABLE 113, 12021 (2000).

238 See generally, e.g., Lurigio \& Snowden, supra note 233 (describing "a recently developedbut fast-growing-strategy for dealing with the challenges of [people with serious mental illnesses] during the pre- and post-adjudication stages of the criminal justice process: mental health court (MHC)").

${ }_{239}$ Goodale, Callahan \& Steadman, supra note 43, at 299 ("When the reduced recidivism rate in this and other MHC studies was compared with the most recent results from drug court research, MHCs were more successful at reducing recidivism - recidivism rates of $25 \%$ versus $10 \%-15 \%[$.]"); accord PERLIN \& CUCOLO, CIVIL AND CRIMINAL, supra note 6, § 1-2.2.3 n.194 (citing inter alia Redlich \& Han, supra note 43, at 116 (finding that "increased levels of initial perceived voluntariness and procedural justice, and MHC knowledge, led to decreased rates of new arrests, prison, MHC bench warrants, and increased court compliance, which, in turn, led to a higher likelihood of MHC graduation")); id. § 4-3.3 n.1384 (citing Munetz, supra note 45, at 356, which found that mental health court graduates perceived significantly less coercion and more procedural justice in court than those involved in assisted outpatient treatment proceedings); see also Evan M. Lowder, Sarah L. Desmarais \& Daniel J. Baucom, Recidivism Following Mental Health Court Exit: Between and Within-Group Comparisons, 40 LAW \& HUM. BEHAV. 118, 124-25 (2016) (demonstrating that mental health courts are particularly effective for high-risk participants, and time spent in such courts has positive effects on recidivism). Some suggest, however, that recidivism studies based on mental health participants are not yet methodologically reliable. But see Laura N. Honegger, Does the Evidence Support the Case for Mental Health Courts? A Review of the Literature, 39 LAW \& HuM. BEHAV. 478, 478 (2015) ("[E]xisting studies of mental health courts suffer from methodological limitations, specifically, a lack of experimental design, use of nonrepresentative samples, and assessment over short timeframes."); Evan M. Lowder, Candalyn B. Rade \& Sarah L. Desmarais, Effectiveness of Mental Health Courts in Reducing Recidivism: A Meta-Analysis, 69 PSYCHIATRIC SERVS. 15, 15 (2017) (finding a small effect of mental health court participation on recidivism relative to traditional criminal processing, and that mental health courts were actually most effective with respect to jail time and charge outcomes rather than with arrest and conviction).

240 See Roger A. Boothroyd et al., The Broward Mental Health Court: Process, Outcomes, and Service Utilization, 26 INT'L J. L \& PSYCHIATRY 55, 55 (2003) (finding that involvement with mental health courts may increase likelihood of accessing treatment); Priscilla Ferrazzi \& Terry Krupa, Mental Health Rehabilitation in Therapeutic Jurisprudence: Theoretical Improvements, 46 INT'L J. L. \& PSYCHIATRY 42, 46 (2016) (arguing that greater consideration of mental health rehabilitation will improve the theoretical validity of therapeutic jurisprudence in the context of mental health courts); Sarah Kopelovich et al., Procedural Justice in Mental Health Courts: Judicial Practices, Participant Perceptions, and Outcomes Related to Mental Health Recovery, 36 INT'L J. L. \& PSYCHIATRY 113, 117 (2013) (finding that procedural justice positively correlated with study participants' attitudes toward their own recovery); Norman G. Poythress et al., Perceived Coercion and 
Certainly, this data tells us that this kind of blur is a salutary and positive one, ${ }^{241}$ unlike the ones discussed previously in this article. By blurring the lines between criminal courts and treatment, mental health courts address social justice needs for the population in question and allow such individuals to be successfully diverted away from the criminal justice system, making it less likely that persons with mental disabilities will suffer at the hands of others-both other inmates and correctional staff ${ }^{242}$ - because of their status.

\section{B. The ADA.}

The application of the Americans with Disabilities Act (ADA) to persons in both psychiatric hospitals and correctional facilities is another example of the positive effects that can potentially occur from "blurring." In Olmstead v. L.C. ex rel. Zimring, the Supreme Court held that unjustified isolation is discrimination based on disability and that Title II of the ADA requires States to provide community-based treatment. ${ }^{243}$ Further, the Supreme Court has held that Title II of the ADA "unambiguously extends to state prison inmates[.]"244 Absent the reasonable accommodations provided for under that title, prisoners with disabilities are "less able to engage meaningfully in prison activities as offered to the general population"245 that may decrease the likelihood of recidivism in the future. In addition, "they are more vulnerable to misunderstanding and exploitation by other prisoners and correctional staff,"246 increasing the likelihood of present and future injury.

Procedural Justice in the Broward Mental Health Court, 25 INT'L J. L. \& PSYCHIATRY 517, 529 (2002) (discussing the role of perceived coercion in the mental health court process and potential implications for recidivism).

${ }_{241}$ Terry Carney et al., Mental Health Tribunals: "TJ" Implications of Weighing Fairness, Freedom, Protection and Treatment, 17 J. JUD. ADMIN. 46, 54 (2007) (detailing the value of mental health tribunals); Risdon N. Slate, From the Jailhouse to Capitol Hill: Impacting Mental Health Court Legislation and Defining What Constitutes a Mental Health Court, 49 CRIME \& DELINQ. 6, $17,21-22$ (2003) (relaying the common benefits of mental health courts).

${ }^{242}$ Perlin, Insanity Defense and Incompetency Status Required by CRPD \& TJ, supra note 6, at $506-08$ (discussing the harms persons with disabilities often suffer in correctional settings).

${ }^{243}$ Olmstead v. L.C. ex rel. Zimring, 527 U.S. 581, 597, 607 (1999) ("Unjustified isolation, we hold, is properly regarded as discrimination based on disability... [W] conclude that, under Title II of the ADA, States are required to provide community-based treatment for persons with mental disabilities when the State's treatment professionals determine that such placement is appropriate, the affected persons do not oppose such treatment, and the placement can be reasonably accommodated, taking into account the resources available to the State and the needs of others with mental disabilities.").

${ }_{244}$ Pa. Dep't of Corr. v. Yeskey, 524 U.S. 206, 213 (1998); see also Perlin, ADA Impact on Criminal Defendant Institutionalization, supra note 6, at 221-22 (discussing Yeskey, 524 U.S. at 209 and noting that the ADA's language "unmistakably includes State prisons and prisoners within its coverage" and contains no "exception that could cast the coverage of prisons into doubt"); see also Crowell v. Mass. Parole Bd., 74 N.E.3d 618, 623 (Mass. 2017) (discussing in dicta that the ADA applies to parolees).

245 Blanck, supra note 196 , at 314 .

246 Id. 
Courts, however, are split on whether the ADA requires police officers to accommodate an individual's disability during their arrest. ${ }^{247}$ While the Supreme Court in City of San Francisco v. Sheehan did not directly decide the question of whether the ADA applies to arrests, ${ }^{248}$ the Court did state that arrests would be subject to Title II if an arrest qualifies thereunder as an activity in which the arrestee participates or from which the arrestee may benefit. ${ }^{249}$ The Court also stated that arrests would be subject to Title II if the failure to arrest the individual in a manner that reasonably accommodates the disability thereunder constitutes discrimination. ${ }^{250}$

Although the question of whether the ADA applies to arrests has not been decided by the Supreme Court, it has been noted that a "number of advocacy and law enforcement agencies have already recognized this pressing issue and have taken affirmative steps to implement more accommodating policies and practices." ${ }^{251}$ As one commentator notes, "[c]omprehensive police officer training that humanizes people with disabilities" can "best accommodate the individual" by "enabl[ing] officers to make accurate individualized assessments about the level of threat posed and to appropriately modify police procedures[.] ${ }^{1252}$ And as another notes, "[t]he most common method of safely accommodating people with mental disabilities is through the use of a Crisis Intervention Team ("CIT") or Mobile Crisis Team ("MCT")"; such teams "have been shown to reduce the incidence of people with mental illness by as much as nineteen percent."253

\footnotetext{
${ }^{247}$ Compare Hainze v. Richards, 207 F.3d 795, 802 (5th Cir. 2000) (holding that Title II does not apply to officer's on-the-street decisions), with Bircoll v. Miami-Dade County 480 F.3d. 1072, 1085 (10th Cir. 2007) (discussing that plain language of Title II supports inclusion of arrest but declining to enter the "circuits' debate"), with Sheehan v. City \& Cnty. of San Francisco, 743 F.3d 1211, 1232 (9th Cir. 2014) ("The ADA therefore applies to arrests, though we agree with the Eleventh and Fourth Circuits that exigent circumstances inform the reasonableness analysis under the ADA, just as they inform the distinct reasonableness analysis under the Fourth Amendment."), reversed in part \& cert. dismissed in part, 135 S. Ct. 1765 (2015).

${ }_{248}$ City \& Cnty. of San Francisco v. Sheehan, 135 S. Ct. 1765, 1773 (2015) ("Whether the statutory language quoted above applies to arrests is an important question that would benefit from briefing and an adversary presentation. But San Francisco, the United States as amicus curiae, and Sheehan all argue (or at least accept) that [the relevant section of the $\mathrm{ADA}$ ] applies to arrests. No one argues the contrary view. As a result, we do not think that it would be prudent to decide the question in this case.").

${ }^{249}$ Id. (noting that the language of the relevant section of the ADA "would apply to an arrest if an arrest is an 'activity' in which the arrestee 'participat[es]' or from which the arrestee may 'benefi[t].").

${ }^{250}$ Id. ("This same provision also commands that 'no qualified individual with a disability shall be ... subjected to discrimination by any [public] entity.' This part of the statute would apply to an arrest if the failure to arrest an individual with a mental disability in a manner that reasonably accommodates that disability constitutes 'discrimination."').

${ }^{251}$ Michael Pecorini, Note and Comment, Trying to Fit a Square Peg into a Round Hole: Why Title II of the Americans with Disabilities Act Must Apply to All Law Enforcement Agencies, 24 J.L. \& POL'Y 551, 594 (2016) (referring to examples given earlier in that piece).

252 Shanna Rifkin, Note, Safeguarding the ADA's Antidiscrimination Mandate: Subjecting Arrests to Title II Coverage, 66 DUKE L.J. 913, 941 (2017) (advocating for such training).

${ }^{253}$ Carly A. Myers, Police Violence Against People with Mental Disabilities: The Immutable Duty Under the ADA to Reasonably Accommodate During Arrest, 70 VAND. L. REV. 1393, 1412 (2017)
} 
The blur caused by the use of the ADA, whose primary focus in mental disability law cases has typically been civil matters, ${ }^{254}$ is not pretextual and does not raise the same questions as to the inappropriate use of the involuntary-civil-commitment power that are raised both by AOT laws ${ }^{255}$ and SVPAs.

\section{UNEXPLORED BLUR QUESTIONS.}

There are other blur questions that have not been extensively explored. There is a body of case law, for example, dealing with the question of what happens when an in-patient at a psychiatric hospital assaults a staff aide ${ }^{256}$ or another patient, ${ }^{257}$ or what happens when a patient escapes from a facility for persons with disabilities, ${ }^{258}$ or what happens when a patient has voluntary sexual interaction, ${ }^{259}$ or what happens when

(citations omitted).

${ }^{254}$ But note the small universe of cases applying the Americans with Disabilities Act to other criminal-court matters. See PERLIN \& CUCOLO, CIVIL AND CRIMINAL, supra note 6, § 11-2.1 (citing relevant cases); Perlin, ADA Impact on Criminal Defendant Institutionalization, supra note 6, at 221 ("[E] arly case law ... has been skimpy.").

255 See Perlin, Will Olmstead Resuscitate the LRA, supra note 13, at 1044 ("Olmstead requires us to rethink the trend towards outpatient commitment, as reflected in such legislation as New York's 'Kendra's Law.' Outpatient commitment laws began as a means of expanding less restrictive options for inpatients; over the years, they have been transmuted into vehicles for the exertion of greater social control over individuals not in in-patient psychiatric hospitals. Olmstead forces us to reexamine this change of direction and may also-eventually-force us to confront the role of forced medication in the out-patient clinic enterprise.")

${ }^{256}$ See, e.g., In re Clark, 700 A. 2d 781, 782 (D.C. 1997); Copeland v. Warden, No. 00113, 1990 WL 274416, at *1-3 (Conn. Super. Ct. 1990). In contrast, in what one of the authors and a colleague have termed an "idiosyncratic case," a New Jersey trial court has ruled that a disorderly conduct prosecution, based on a complaint filed by an institutional attendant, of an involuntary state hospital patient was cruel and unusual punishment under the Eighth and Fourteenth Amendments. State v. Cummins, 403 A.2d 67, 69 (N.J. Law Div. 1979) ("To convict the involuntary committee of a quasicriminal offense for displaying the symptoms of his illness while in a place intended to treat that illness, and upon the complaint of one whose duty it is to have the care and custody of such a patient, imposes punishment where none can either constitutionally or morally be justified.").

257 See, e.g., People v. Eiffel, 600 N.Y.S. 2d 437, 438 (1993); Doxen v. Wack, 669 N.Y.S.2d 464, 465 (Sup. Ct. 1997).

258 State v. Burgess, 870 P.2d 276, 278 (Utah Ct. App. 1994) (finding no error to transfer defendant from state training school to state prison after he had escaped from initial facility). However, courts have generally construed escape statutes narrowly so as not to include psychiatric facilities, unless the legislation either explicitly includes such institutions. See, e.g., United States v. Wood, 628 F.2d 554, 560 (D.C. Cir. 1980); United States v. Powell, 503 F.2d 195, 196 (D.C. Cir. 1974); State v. Delafose, 441 A.2d 158, 162 (Conn. 1981); People v. Ortega, 487 N.Y.S.2d 939, 943-45 (Sup. Ct. 1985). In all of these cases, the criminal defendant was originally committed to the psychiatric hospital following a finding of not guilty by reason of insanity on a prior criminal charge. See, e.g., PERLIN \& CUCOLO, CIVIL AND CRIMINAL, supra note 6, § 15-5, at 15-76; Grant H. Morris, Escaping the Asylum: When Freedom is a Crime, 40 SAN DIEGO L. REV. 481, 517-30 (2003).

${ }_{259}$ One of the authors has argued elsewhere that the psychiatric hospital patient's right to sexual interaction may be located as part of the right to treatment or as an aspect of the ADA's ban on discrimination. See, e.g., Michael L. Perlin, Hospitalized Patients and the Right to Sexual Interaction: Beyond the Last Frontier?, 20 N.Y.U. REV. L. \& SoC. CHANGE 517, 522-28 (1993-94) [hereinafter Perlin, Sexual Interaction Rights for Hospitalized Patients]; Michael L. Perlin, "Make Promises by the Hour": Sex, Drugs, the ADA, and Psychiatric Hospitalization, 46 DEPAUL L. REV. 947, 965-70 (1997) [hereinafter Perlin, Sex, Drugs, the ADA, and Psychiatric Hospitalization]. Yet, apparently, 
mental health workers convince patients to accept voluntary commitments. ${ }^{260}$ Yet there is, to the best of our knowledge, virtually no legal academic literature ${ }^{261}$ on these issues-although there is significant literature, of course, on the question of arrest rates of ex-hospital patients. ${ }^{262}$ How these questions are dealt with-both from the prosecutorial perspective and the institutional/administrative perspective - may potentially raise important "blur" issues, but this topic remains-somewhat curiously—off the "radar screen" (of legal academics, at least).

\section{THERAPEUTIC JURISPRUDENCE. ${ }^{263}$}

As some of authors have previously written, "[o]ne of the most important legal theoretical developments of the past three decades has been the creation and dynamic growth of therapeutic jurisprudence. ${ }^{.264}$ Thera-

in some jurisdictions, any sort of consensual sexual contact between patients leads to an "incident report" being filed with the local police. Interview with Dr. R. P. Singh, Rochester Psychiatric Hospital, in Rochester, N.Y. (Feb. 26, 2001) (on file with authors).

${ }^{260}$ There is some intriguing literature that suggests that certain mental health workers act in traditional "Mutt-and-Jeff" police roles in attempting to convince patients to accept voluntary commitments (and not challenge their institutionalization in court proceedings). See Reed \& Lewis, supra note 112 (noting that the most common method for a therapist to obtain consent is through "persuasion and coercion"). This raises other important potential "blur" issues that call out for further scholarly and empirical attention.

${ }_{261}$ There is some older commentary in the forensic psychiatric literature. See, e.g., Gary J. Maier \& Stephen Rachlin, Prosecution of Assaultive Patients, in PRINCIPLES AND PRACTICE OF FORENSIC PSYCHIATRY 699 (Richard Rosner ed., 2d ed. 2003); Kenneth L. Appelbaum \& Paul Appelbaum, $A$ Model Hospital Policy on Prosecuting Patients for Presumptively Criminal Acts, 42 HosP. \& COMMUNITY PSYCHIATRY 1233, 1233-37 (1992); Stephen Rachlin, The Prosecution of Psychiatric Inpatients: One Respectable Intervention, 22 BULL. AM. ACAD. PSYCHIATRY \& L. 239, 239-243 (1994). Of these articles, only one-written by Appelbaum and Appelbaum-has ever been cited in the legal literature, and that article was written by a forensic psychiatrist. See Robert D. Miller, The Continuum of Coercion: Constitutional and Clinical Considerations in the Treatment of Mentally Disordered Persons, 74 DENV. U. L. REV. 1169, 1184 n.82 (1997) [hercinafter Miller, Coercion in Treatment] (citing Appelbaum \& Appelbaum, supra note 261).

${ }^{262}$ See, e.g., Marnie E. Rice \& Grant T. Harris, The Treatment of Mentally Disordered Offenders, 3 PSYCHOL. PUB. POL'Y \& L. 126, 128 (1997) (citing articles); Miller, Coercion in Treatment, supra note 262 , at $1183 \mathrm{n} .75$ (citing sources).

263 Text infra accompanying notes $264-76$ is partially adapted from Michael L. Perlin \& Alison J. Lynch, "All His Sexless Patients": Persons with Mental Disabilities and the Competence to Have Sex, 89 WASH. L. REV. 257 (2014); Michael L. Perlin \& Alison J. Lynch, "In the Wasteland of Your Mind": Criminology, Scientific Discoveries and the Criminal Process, 4 VA. J. CRIM. L. 304 (2016); Weinstein \& Perlin, Cycle Deprives Continuity of Care, supra note 35. Further, it distills the work of one of the authors over the past quarter-century, beginning with Michael L. Perlin, What Is Therapeutic Jurisprudence?, 10 N.Y.L. SCH. J. HUM. RTS. 623 (1993) [hereinafter Perlin, What is Therapeutic Jurisprudence?], and continuing to Michael L. Perlin, "Have You Seen Dignity?": The Story of the Development of Therapeutic Jurisprudence, 27 U.N.Z. L. REV. 1135 (2017), and Michael L. Perlin, "Changing of the Guards": David Wexler, Therapeutic Jurisprudence, and the Transformation of Legal Scholarship, INT'L J.L. \& PSYCHIATRY, July 19, 2018, available at https://doi.org/10.1016/j.ijlp.2018.07.001 [hereinafter Perlin, Wexler, TJ, and Transformation of Legal Scholarship].

${ }^{264}$ Weinstein \& Perlin, Cycle Deprives Continuity of Care, supra note 35, at 481 . The first use of the term was in a paper David Wexler presented to the National Institute of Mental Health in 1987. See David B. Wexler, Putting Mental Health into Mental Health Law: Therapeutic Jurisprudence, 
peutic jurisprudence (TJ), as the authors previously wrote, "presents a new model for assessing the impact of case law and legislation, recognizing that, as a therapeutic agent, the law can have therapeutic or antitherapeutic consequences." ${ }^{265}$ TJ may lend understanding and offer remediating suggestions and/or solutions to the blur issues discussed in prior parts of this article.

TJ "asks whether legal rules, legal procedures, and lawyer roles can or should be reshaped to enhance their therapeutic potential while not subordinating due-process principles." ${ }^{266}$ David Wexler, who first coined the term, ${ }^{267}$ identifies clearly how the tension inherent in this inquiry must be resolved: the law's use of mental health information to improve therapeutic functioning cannot impinge upon justice concerns. ${ }^{268}$ As one of the authors has written elsewhere, "[a]n inquiry into therapeutic out-

16 LAW \& HUM. Behav. 27, 27, 32-33 (1992) [hereinafter Wexler, Putting Mental Health into Mental Health Law] (discussing the role of therapeutic jurisprudence in modern mental health law); David B. Wexler, The Development of Therapeutic Jurisprudence: From Theory to Practice, 68 REV. JUR. U. P.R. 691, 693-94 (1999) (chronicling Wexler's creation of the term "therapeutic jurisprudence"). On Wexler's contributions to this field, see Perlin, Wexler, TJ, and Transformation of Legal Scholarship, supra note 263. For collections of works on the topic of therapeutic jurisprudence that have been edited by Wexler, see THERAPEUTIC JURISPRUDENCE: THE LAW AS A THERAPEUTIC AGENT (David B. Wexler ed., 1990); LAW IN A THERAPEUTIC KEY: RECENT DEVELOPMENTS IN THERAPEUTIC JuRISPRUdence (David B. Wexler \& Bruce J. Winick eds.,1996); CivIL COMMITMENT: A THERAPEUTIC JURISPRUDENCE MODEL (David B. Wexler ed., 2005).

${ }^{265}$ Weinstein \& Perlin, Cycle Deprives Continuity of Care, supra note 35, at 481-482; see also Michael L. Perlin, "His Brain Has Been Mismanaged with Great Skill": How Will Jurors Respond to Neuroimaging Testimony in Insanity Defense Cases?, 42 AKRON L. REV. 885, 912 (2009) (noting that "by studying the role of the law as a therapeutic agent; recognizing that substantive rules, legal procedures, and lawyers' roles may have either therapeutic or anti-therapeutic consequences" and echoing David B. Wexler \& Bruce J. Winick, Therapeutic Jurisprudence and Criminal Justice Mental Health Issues, 16 MENTAL \& PHYSICAL DISABILITY L. REP. 2, 225 (1992) [hereinafter Wexler \& Winick, TJ \& Criminal Justice Mental Health Issues], which therein noted that "[o]ur research interests have increasingly focused on what we have come to call 'therapeutic jurisprudence'- the extent to which substantive rules, legal procedures, and the roles of lawyers and judges produce therapeutic or antitherapeutic consequences"); see also, Kate Diesfeld \& Ian Freckelton, Mental Health Law and Therapeutic Jurisprudence, in DISPUTES AND DILEMMAS IN HEALTH LAW 91 (Ian Freckelton \& Kate Peterson eds., 2006) (offering a transnational perspective).

${ }^{266}$ Weinstein \& Perlin, Cycle Deprives Continuity of Care, supra note 35, at 482; see also Perlin, Counsel's Role in Right to Refuse Treatment, supra note 37, at 751; Ian Freckelton, Therapeutic Jurisprudence Misunderstood and Misrepresented: The Price and Risks of Influence, 30 T. JEFFERSON L. REV. 575, 585-86 (2008).

267 Wexler, Putting Mental Health into Mental Health Law, supra note 264, at 27.

268 See David B. Wexler, Applying the Law Therapeutically, 5 APPLIED \& PREVENTIVE PSYCHOL. 179, 184-85 (1996) (quoting David B. Wexler, Reflections on the Scope of Therapeutic Jurisprudence, 1 PSYCHOL. PUB. POL'Y \& L. 220, 236 (1995), as saying that "[u]ltimate law reform might be accomplished by therapeutic jurisprudence scholars persuading certain administrators of the ADA, who in this case are employers, to urge employees with disabilities to consider the waiver of the confidentiality provision. The matter is subject to individual tailoring because, for some employees, confidentiality will outweigh the interest in co-worker involvement, but for others it will not. Moreover, this change is easier to accomplish than changing the confidentiality law itself. Changing the confidentiality law itself would be tremendously controversial and would raise all sorts of justice concerns. The administrative solution, on the other hand, leads to a convergence between justice and therapeutic concerns: Confidentiality is preserved for those who deem it important to them, and yet divulgence and co-worker involvement are made available to those who wish to follow that route for hoped-for therapeutic gains"); David B. Wexler, Therapeutic Jurisprudence and Changing Concepts of Legal Scholarship, 11 BEHAV. SCI. \& L. 17, 21 (1993) ("The key task is, of course, to determine how the law can use mental health information to improve therapeutic functioning without impinging upon justice concerns."). 
comes does not mean that therapeutic concerns 'trump' civil rights and civil liberties.,269

Using TJ, we "look at law as it actually impacts people's lives" and assess law's influence on emotional life and psychological wellbeing. ${ }^{271}$ One governing TJ principle is that "law should value psychological health, should strive to avoid imposing anti-therapeutic consequences whenever possible, and when consistent with other values served by law should attempt to bring about healing and wellness."272 $\mathrm{TJ}$ supports an "ethic of care."273

One of the central principles of TJ is a commitment to dignity. ${ }^{274}$ Professor Amy Ronner describes the "'the three V's': namely, a sense of voice, validation, and voluntary participation."275 She argues that litigants must have a sense of being genuinely heard, which leads to a feeling of validation and that they are voluntarily partaking in the process that will initiate healing and bring about improved behavior in the future. ${ }^{276}$

The questions to be addressed here include these: In light of what we have discussed in the prior parts of this article, to what extent does TJ offer remediating suggestions and/or solutions? How can TJ help us understand the blur issues that are the subject of this article?

\footnotetext{
269 Perlin, What is Therapeutic Jurisprudence?, supra note 263, at 412; see also Perlin, Us and Them, supra note 36 , at 782 .

270 Bruce J. Winick, Foreword: Therapeutic Jurisprudence Perspectives on Dealing with Victims of Crime, 33 NOVA L. REV. 535, 535 (2009) ("[TJ] is a descendant of legal realism, which asks us to look at law as it actually impacts people's lives, and to do so using perspectives and approaches drawn from other disciplines[.]").

271 See generally David B. Wexler, Practicing Therapeutic Jurisprudence: Psychological Soft Spots and Strategies, in DANIEl P. STOLle, DAVID B. WEXlER \& BRUCE J. WINICK, PRACTICING THerapeUtiC JURISPRUdenCE: LAW AS A HeLPING PROFESSION 45 (2006).

${ }^{272}$ Bruce J. Winick, A Therapeutic Jurisprudence Model for Civil Commitment, in INVOLUNTARY DETENTION AND THERAPEUTIC JURISPRUDENCE: INTERNATIONAL PERSPECTIVE ON CIVIL COMMITMENT 23, 26 (Kate Diesfeld \& Ian Freckelton eds., 2003).

${ }^{273}$ See, e.g., Bruce J. Winick \& David B. Wexler, The Use of Therapeutic Jurisprudence in Law School Clinical Education: Transforming the Criminal Law Clinic, 13 CLINICAL L. REV. 605, 605 (2006) ("Recent years have seen the emergence of the therapeutic jurisprudence/preventive law model of lawyering. This model contemplates lawyers practicing with an ethic of care[.]").

274 See Bruce J. Winick, Civil Commitment: A Therapeutic JuRisPrudenCE Model 161 (2005) (stating that involuntary commitment hearings serve an important dignitary value).

275 See Amy D. Ronner, Songs of Validation, Voice, and Voluntary Participation: Therapeutic Jurisprudence, Miranda and Juveniles, 71 U. CIN. L. REV. 89, 93-96 (2002) (discussing " "the three V's': namely, a sense of voice, validation, and voluntary participation."); see also Freckelton, supra note 266 , at 588 (discussing the importance of "voice").

${ }^{276}$ See Ronner, supra note 275 , at 94-95 ("Voice and validation create a sense of voluntary participation, one in which the litigant experiences the proceeding as less coercive."); see generally AMY D. RONNER, LAW, LITERATURE, AND THERAPEUTIC JURISPRUDENCE (2010) (examining the psychological aspects of the legal system relating to therapeutic jurisprudence).
} 


\section{A. TJ and "Negative Blur" Issues.}

\section{TJ and AOT Laws.}

Again, consider some of the objections to AOT legislation: that it sanctions forcible medical treatment without a finding of patient incompetence and instead "only requires a finding that the patient is 'unlikely" to survive in the community, leaving unclear its relevance to a finding of incompetence."277 Particularly with regard to "mandatory outpatient medication," this represents a "paternalism creep that should only be legitimized after it is measured against the disability rights goals of fostering autonomy and facilitating human flourishing." 278 The TJ literature has extensively considered the issues of both forced medication and determinations of incompetency. ${ }^{279}$ By way of example, Professor David Katner has written that " $[\mathrm{t}]$ he principles of therapeutic jurisprudence ... should be applied to the process of redrafting competency statutes." ${ }^{280}$ We believe this should be done comprehensively for all aspects of AOT law.

TJ principles must be employed in cases involving persons with mental disabilities subject to AOT laws. ${ }^{281}$ In particular, "[j] udges, court personnel, treatment providers, and defense attorneys should take care to instruct the [offenders] carefully and understandably concerning [their] obligations relating to participation in the treatment program and reporting to court." 282 Most importantly, the person should not feel coerced in-

277 Emily S. Huggins, Assisted Outpatient Treatment: An Unconstitutional Invasion of Protected Rights or a Necessary Government Safeguard?, 30 J. LEGIS. 305, 319 (2004) (discussing Kendra's Law).

${ }^{278}$ Accord John V. Jacobi, Mental Illness: Access and Freedom, 16 HoUS. J. HEALTH L. \& POL'Y 37,72 (2016).

${ }^{279}$ See generally Bruce J. Winick, Competency to Consent to Treatment: The Distinction between Assent and Objection, 28 HoUS. L. REV. 15 (1991); see also, e.g., Jan C. Costello, Why Have Hearings for Kids if You're Not Going to Listen?: A Therapeutic Jurisprudence Approach to Mental Disability Proceedings for Minors, 71 U. CIN. L. REV. 19, 27 (2002); David R. Katner, Eliminating the Competency Presumption in Juvenile Delinquency Cases, 24 CORNELL J.L. \& PUB. POL'Y 403, 408 (2015); Donald Stone, The Dangers of Psychotropic Medication for Mentally Ill Children: Where Is the Child's Voice in Consenting to Medication? An Empirical Study, 23 TEMP. POL. \& CIV. RTS. L. REV. 121, 122 (2013).

${ }_{280}$ Katner, supra note 279, at 433; see also Gene Griffin \& Michael J. Jenuwine, Using Therapeutic Jurisprudence to Bridge the Juvenile Justice and Mental Health Systems, 71 U. CIN. L. REV. 65, 66-67, 87 (2002).

281 Accord Perlin, TJ \& Kendra's Law, supra note 24, at 194-95.

${ }^{282}$ Bruce J. Winick, Therapeutic Jurisprudence and Problem Solving Courts, 30 FORDHAM URB. L.J. 1055, 1084 (2003) [hereinafter Winick, TJ and Problem Solving Courts] ("The judge should act concerned rather than distant, provide the individual with her undivided attention during conversations, avoid jargon, allow the individual an opportunity for voice, avoid paternalism, and generally treat the individual with respect."). On how TJ specifically affects, not just clients, victims, and their families, "but also legal actors, such as attorneys, paralegals, investigators, judges, and court personnel," see Michael D. Jones, Teaching TJ: Therapeutic Jurisprudence for Law Students, 3 SUFFOLK 
to treatment or into agreeing to the program. ${ }^{283}$ As noted previously, "[c]oercion is more likely to inspire distrust of the therapist, resentment, and lack of genuine cooperation.,"284

One of the factors required for the imposition of court-ordered AOT in New York is a finding that the person is unlikely to participate in outpatient treatment voluntarily. ${ }^{285}$ However, "[c]linical judgments regarding a patient's level of insight are extraordinarily difficult to challenge in court" and may "depend on the patient's attitudes toward treatment and whether patients agree with their diagnosis." ${ }^{286}$ This would seem to run counterintuitive to the principles of TJ. Instead, AOT laws should provide for preventive outpatient hearings that are "structured in ways that accord patients a sense of procedural justice, treating them with fairness, dignity, and respect, attempting to motivate them to accept treatment rather than coercing them to do so."287

\section{TJ and SVPAs.}

Consider next the issues surrounding SVPAs. If we begin by looking at the Supreme Court's 1997 decision in Kansas v. Hendricks ${ }^{288}$ from a therapeutic jurisprudence perspective, that case's pretextuality becomes clear. ${ }^{289}$ To start, consider Professor Keri Gould's eight TJ-based questions that she asked about Hendricks twenty years ago-questions that we think can also be asked about Hendricks's successors as well. ${ }^{290}$ Yet,

U. L. REV. ONLINE 25, 25 (2015).

283 Winick, TJ and Problem Solving Courts, supra note 282, at 1079-80.

${ }^{284}$ Winick, Outpatient Commitment TJ Analysis, supra note 115, at 120.

285 N.Y. MENTAL HYG. LAW $\S 9.60(\mathrm{C})(5)(2015)$.

286 Player, supra note 105, at 216.

287 Winick, Outpatient Commitment TJ Analysis, supra note 115 , at 135 . For a TJ-based analysis of an AOT law proposed in Ohio, see Jessica L. MacKeigan, Violence, Fear, and Jason's Law: The Needless Expansion of Social Control over the Non-Dangerous Mentally Ill in Ohio, 56 CLEV. ST. L. REV. 739, 742 (2008) ("[T] proposed law would cast a much wider net, provide less due process protections, and ultimately be more restrictive of the rights of non-dangerous persons than current law is for presently dangerous individuals.").

288 Hendricks, 521 U.S. at 346.

289 Perlin, Exposing Pretextuality in Hendricks, supra note 39, at 1274.

290 Keri Gould, Remarks at American Association of Law Schools Section on Law and Mental Disability Panel Discussion (Jan. 1998) [hereinafter Gould, Remarks] (noting the following questions: (1) Is Hendricks therapeutic for the public or for victims?, (2) After Hendricks, does the (allegedly) "dispassionate" police power give way so as to satiate public rage?, (3) Is it possible for any such scheme to be therapeutic without the provision of mandatory post-release outreach?, (4) Does the fact that therapy does not start (under the Kansas statute, at least) until after the defendant's sentence ends attenuate any potential therapeutic outcomes?, (5) Is coerced sex offender treatment therapeutic?, (6) Is there any incentive for a defendant to engage in any meaningful therapy programs while in prison if what is said during such participation can be used against the defendant after his sentence terminates?, (7) Will Hendricks lead to long-term commitments of those who "act out" sexually at civil mental hospitals?, (8) Will Hendricks lead some prosecutors to use involuntary civil commitment as a means of "boosting" criminal cases?); see also, Keri Gould, If It's a Duck and Dangerous-Permanently Clip Its Wings or Treat It Till It Can Fly?: A Therapeutic Perspective on 
some of these questions have still not been answered adequately.

There is more. ${ }^{291}$ By way of example, from a TJ perspective, Professor Dale Dewhurst has concluded that lawyers must engage with other behavioral experts in these cases so as to adequately represent their clients and, optimally, share with the court treatment models that reject punitive approaches that have not been found to reduce recidivism. ${ }^{292}$ Counsel must familiarize herself with approaches to such cases that go "beyond the legalistic skills of the lawyers" 293 so as to best embody the TJ value of "zealous counseling" that Robert Ward has urged. ${ }^{294}$ By way of example, if counsel were to be familiar with such approaches as the RiskNeeds-Responsivity Model or the Good Lives Model of offender rehabilitation, ${ }^{295}$ it is far more likely that TJ values would be enhanced. ${ }^{296}$

Through its emphasis on increasing therapeutic effects and decreasing anti-therapeutic consequences of the law, TJ has been suggested by Dr. Astrid Birgden to provide the best framework to ensure protection of

Difficult Decisions, Short-Sighted Solutions and Violent Sexual Predators After Kansas v. Hendricks, 31 LOY. L.A. L. REV. 859, 880-81 (1998); see also Perlin, Exposing Pretextuality in Hendricks, supra note 39, at 1274 (quoting Gould, Remarks, supra note 290).

291 See generally PERLIN \& CUCOLO, DETRIMENTS OF SVP LEGISLATION, supra note 27, at 16768. On how decisions such as Kansas v. Hendricks, 521 U.S. 346 (1997), may be part of the profoundly anti-therapeutic "transinstitutionalization process" through which "legislators dissatisfied with outcomes in the correctional system, such as the release of sex offenders, seek to use the mental health system to confine offenders for longer periods of time," see Peter Margulies, The New Class Action Jurisprudence and Public Interest Law, 25 N.Y.U. REV. L. \& SOC. CHANGE 487, 515 n.139 (1999).

${ }^{292}$ See Dale Dewhurst, Understanding the Legal Client's Best Interests: Lessons from Therapeutic Jurisprudence and Comprehensive Justice, 6 PHOENIX L. REV. 963, 999-1003 (2013) (noting that "[l]awyers must actively engage other professionals if they have any hope of meeting their clients" actual best interests" and citing DORIS LAYTON MACKENZIE, WHAT WORKS IN CORRECTIONS: REDUCING THE CRIMINAL ACTIVITIES OF OFFENDERS AND DELINQUENTS 333, 333 (2006), which states that "[n]one of the interventions focusing on punishment, deterrence, or control were found to reduce recidivism"). One relatively-recent state study (Minnesota) has concluded that just nine percent of civilly committed sex offenders would have been reconvicted of a sex offense had they been released to the community. See Grant Duwe, To What Extent Does Civil Commitment Reduce Sexual Recidivism? Estimating the Selective Incapacitation Effects in Minnesota, 42 J. CRIM. JUST. 193, 199-200 (2014) ("[F]indings suggest that 10 of the 105 civilly committed sex offenders would likely have been reconvicted of a new sex offense within four years.").

293 See Dewhurst, supra note 292, at 1002 ("Obviously, much more could be said about theories of offender rehabilitation. What is clear is that these new approaches go beyond the adversarial approach, beyond the legalistic skills of the lawyers.").

${ }^{294}$ Id. at 971-72 (quoting Robert Ward, Criminal Defense Practice and Therapeutic Jurisprudence: Zealous Advocacy through Zealous Counseling: Perspectives, Plans and Policy, in REHABILITATNG LAWYERS: PRINCIPLES OF THERAPEUTIC JURISPRUDENCE FOR CRIMINAL LAW PRACTICE 206, 206-25 (David B. Wexler ed., 2008)).

295 Id. at 1000-02 (noting that "two of the approaches that seem to be producing the most effective results are the Risk-Needs-Responsivity Model ('RNR') of offender rehabilitation and the Good Lives Model ('GL')" and citing, inter alia, Tony Ward \& Shadd Maruna, REHABILITATION: BEYOND THE RISK PARADIGM 46 (2007)); see also Birgden, TJ and Sex Offenders, supra note 169, at 353.

296 Gwenda M. Willis et al, How to Integrate the Good Lives Model Into Treatment Programs for Sexual Offending an Introduction and Overview, 25 SEXUAL ABUSE: J. RES. \& TREATMENT 123, 128-29 (2013) (finding that GLM better takes into account the diversity of offenders in relation to age, learning style, culture, and various barriers to participation); Gwenda M. Willis, Tony Ward \& Jill S. Levenson, The Good Lives Model (GLM): An Evaluation of GLM Operationalization in North American Treatment Programs, 26 SEXUAL ABUSE: J. RES. \& TREATMENT 58, 77 (2014) (stating that the factor most frequently reported as supporting adoption of the GLM was that clients were particularly responsive to the application of the model). 
both sex offenders and the community. ${ }^{297}$ Such a system must focus on a collaboration of efforts between legal practitioners, correctional practitioners, and the court system. ${ }^{298}$ If there is also focus on both community and offender protection, ${ }^{299}$ a psycho-legal approach can successfully address sex offender assessment (risk and need principles), treatment (need and internal responsivity principles), and management (external responsivity principles). In court, mental health practitioners can advise on offender rehabilitation techniques (offender protection) as well as assist legal practitioners so that they can maintain an environment that assists offenders in engaging in treatment (community protection). ${ }^{300}$ In the corrections setting, legal practitioners can provide advice on ethical treatment (offender protection) while mental health practitioners can increase the courts' confidence in rehabilitation (community protection). TJ might also be used to support the principle of desistance. ${ }^{301}$

As one of the authors noted previously with another colleague, "[c]learly, we must focus our efforts and resources on reintegration into society rather than removal and alienation. Sex offender civil commitment is not going by the wayside, and, following the decision in United States $v$. Comstock, it may gain more support. ${ }^{302}$ "Given the limited effectiveness and knowledge of conventional treatment combined with the lengthy and indefinite time sex offenders spend in civil commitment, states should reallot their resources and focus on fostering rehabilitation and reintegration into the community." 303 The aim of sex offender legal

\footnotetext{
297 See generally Birgden, TJ and Sex Offenders, supra note 169.

298 Accord Astrid Birgden \& Heather Ellis Cucolo, The Treatment of Sex Offenders: Evidence, Ethics and Human Rights, 23 SEXUAL ABUSE: J. RES. \& TREATMENT 295, 306 (2011) (noting that TJ's support of due process in law in this context is "rarely considered by practitioners in corrections").

${ }^{299}$ See Bill Glaser, Treaters or Punishers? The Ethical Role of Mental Health Clinicians in Sex
} Offender Programs, 14 AGGRESSION \& VIOLENT BEHAV. 248, 250 (2009) (noting that, for example, an earlier version of the Practice Standards and Guidelines adopted by the US Association for the Treatment of Sexual Abusers "endorse[d] a number of practices which seemingly promote an offender's welfare" but unfortunately that "[e]ven so, it is clear that the interests of the community always trump those of the offender").

300 See $i d$. (proposing a system in which "[c]linicians can remind police, corrections officers, legal professionals and, of course, offenders themselves that not all offenders are incorrigible, that relationships with them need not always be marred by conflict, and that harsh punishment is not the only, or even the most desirable, solution to criminal behavior.").

301 Dr. Birgden has also argued that TJ can be used to support the principle of desistance-a gradual or emergent process, cast in a human rights framework, through which people cease and refrain from persistent offending. See Astrid Birgden, Maximizing Desistance Adding Therapeutic Jurisprudence and Human Rights to the Mix, 42 CRIM. JUST. \& BEHAV. 19, 26 (2005) (discussing desistance in an international human rights setting); see generally Svenja Göbbels, Gwenda M. Willis \& Tony Ward, Current Re-Entry Practices' in Sex Offender Treatment Programmes: Desistance Facilitating or Hindering?, 20 J. SEXUAL AGGRESSION 354 (2014) (discussing desistance in the specific context of the treatment of sexual offenders); SHADD MARUNA, MAKING GOOD: How EX-CONVICTS REFORM AND REBUILD THEIR LIVES (2001).

302 Cucolo \& Perlin, Preventing Sex-Offender Recidivism through TJ, supra note 127, at 40.

${ }^{303}$ Id. (citing Eric S. Janus, The Preventive State, Terrorists, and Sexual Predators: Countering the Threat of a New Outsider Jurisprudence, 40 CRIM. L. BULL. 576, 580-81 (2004) ("Arising out of a combination of social forces, the [sexually violent predator] laws reflect both a new consciousness about the seriousness of sexual violence, and a public frustration with the limited effectiveness of 
reform "should be to facilitate the rehabilitation of offenders." 304 And "[i]f we continue to support civil commitment under the guise of treatment and the hope that individuals can be treated, then ethically, we must tailor treatment to assist in reentering society." 305 Our "[f]ocus should follow TJ ideals and aim to promote self-respect and dignity while learning to engage in emotionally intimate relationships with others"; "[p]reparation for release should include job training, education, and life skills. We must support the transition back into the community by fostering family and community relationships."306

\section{TJ and Imprisoning Insanity Acquittees. ${ }^{307}$}

The rationale behind the insanity defense is that a fair and moral system does not punish those persons with mental illness who inherently lack criminal intent. ${ }^{308}$ The defense "is used to identify offenders for

conventional approaches....In practice, however, committed sex offenders are very rarely discharged from these treatment facilities. The primary, articulated purpose for these laws is incapacitation-prevention of future sexual violence by means of direct physical constraint. Treatment is identified as an additional purpose.").

304 Accord Jason E. Peebles, Therapeutic Jurisprudence and the Sentencing of Sexual Offenders in Canada, 43 INT'L J. OFFENDER THERAPY \& COMP. CRIMINOLOGY 275, 287 (1999).

${ }^{305}$ Cucolo \& Perlin, Preventing Sex-Offender Recidivism through TJ, supra note 127, at 40 (citing Hollida Wakefield, The Vilification of Sex Offenders: Do Laws Targeting Sex Offenders Increase Recidivism and Sexual Violence?, 1 J. SEXUAL OFFENDER CIV. COMMITMENT; SCI. \& L. 141, 146 (2006) (citing John Q. LaFond, The Future of Involuntary Civil Commitment in the U.S.A. after Kansas v. Hendricks, 18 BEHAV. SCI. \& L. 153, 153-167 (2000) and noting that though "[t]he SVP laws were passed with the promise of rehabilitation as a major goal," LaFond therein "observes that in some states, there was no bona fide treatment program in place when the individuals were committed")).

306 Id. at 40; accord generally ROBERT PRENTKY \& BARBARA K. SCHWARTZ, TREATMENT OF $\begin{array}{lllll}\text { ADULT } & \text { SEX } & \text { OFFENDERS } & 9 & \text { (2006), }\end{array}$ https://www.niwrc.org/sites/default/files/documents/Resources/Treatment-of-Adult-Sex-

Offenders.pdf [https://perma.cc/68CK-28U9] (discussing the limited effectiveness of treatment alone based on studies but that " $[t]$ he most important point, however, is that the overarching goal of reducing sexual violence in society must rest squarely with the forces within society that promote and foster sexual violence. By merely reducing the risk of those who have already turned to sexual violence, we will never achieve the ultimate aim of making society a safer place by restoring the rights to sexual autonomy for women and children").

307 The first important article assessing insanity acquittee policies from a therapeutic jurisprudence perspective was David B. Wexler, Health Law Compliance Principles and the Insanity Acquittee Conditional Release Process, 27 CRIM. L. BULL. 18 (1991).

${ }_{308}$ Jonas Robitscher \& Andrew K. Haynes, In Defense of the Insanity Defense, 31 EMORY L.J. 9, 9-10 (1982) (quoting Durham v. United States, 214 F.2d 862, 876 (D.C. Cir. 1954) when noting that "Anglo-Saxon law historically has upheld the maxim that 'our collective conscience does not allow punishment where it cannot impose blame""); see also Galloway v. State, 938 N.E.2d 699, 716 (Ind. 2010) (explaining that a legally insane person is unable to form the requisite criminal intent for commission of a criminal act); Perlin, Insanity Defense and Incompetency Status Required by CRPD \& TJ, supra note 6, at 492 (citing Robert L. Sadoff \& Frank M. Dattilio, Criminal Responsibility, in HANDBOOK OF FORENSIC ASSESSMENT: PSYCHOLOGIC AND PSYCHIATRIC PERSPECTIVES 121 (Etic Y. Drogin et al. eds., 2011) and $2 \mathrm{H}$. BRACTON, DE LEGIBUS ET CONSUETUDINIBUS ANGLIAE 424 (Longman \& Thorne trans., 1968) to note that " $[\mathrm{h}]$ istorically, the defense has been "a major component of the Anglo-American common law for over 700 years," and citing Daniel P. Greenfield, Criminal Responsibility from a Clinical Perspective, 37 J. PSYCHIATRY \& L. 7 (2009) to note that it is "[r] ooted in Talmudic, Greek, and Roman history" and that "its forerunners can actually be traced 
whom punishment would not serve the three policy rationales of deterrence, retribution, and rehabilitation." ${ }^{309}$ Since the Model Penal Code's publication over sixty years ago, ${ }^{310}$ the purpose of the defense-at least theoretically-has been separating out the criminally culpable, who ought to be sentenced to effectuate the purposes of the criminal law, from those who are ill and in need of medical treatment without the stigma of criminality attaching. ${ }^{311}$ Insanity defendants lack the capacity to be morally blameworthy. ${ }^{312}$

Thus, when a person is found "not guilty by reason of insanity," typically, he or she is sent to a psychiatric hospital where the punishment rationales of penal sanctions are not implicated. ${ }^{313}$ But one of the authors has argued previously that, subsequent to Olmstead, ${ }^{314}$ there is still a violation of the ADA when "policies that mandate that ... all [insanity] acquittees must be evaluated, treated, or confined only in a state's maximum security facility for the criminally insane[.] ${ }^{315}$ Others have argued that commitment in maximum security facilities may also violate the principles underlying the LRA. ${ }^{316}$

This backdrop makes it crystal-clear that state laws that allow for the imprisonment of insanity acquittees_-besides being bad law and bad policy-squarely violate the principles of $\mathrm{TJ}$. There is no question that insanity acquittees are often held in forensic facilities for longer than is warranted by the underlying crimes with which they were charged. ${ }^{317}$ And again, one of the authors has previously argued that $\mathrm{TJ}$ principles must be more rigorously applied to issues involving post-acquittal insti-

\footnotetext{
back over 3000 years").

309 Accord Julie E. Grachek, The Insanity Defense in the Twenty-First Century: How Recent United States Supreme Court Case Law Can Improve the System, 81 IND. L.J. 1479, 1482 (2006).

310 See, e.g., Perlin, Insanity Defense and Incompetency Status Required by CRPD \& TJ, supra note 6, at 500 n.167 (referencing a draft of the Model Penal Code in 1962).

311 See, e.g., Mental Disease or Defect Excluding Responsibility, MODEL PENAL CODE $\$ 4.01 \mathrm{cmt}$. 2 (AM. LAW INST., Tent. Draft No. 4, 1955) (setting forth an illustration of a man strangling his wife while sincerely believing he was squeezing lemons).

${ }^{312}$ Accord generally Perlin, Insanity Defense \& Fear of Faking, supra note 36, at 1396-97 (citing, in part, Susan N. Herman, The Insanity Defense in Fact and Fiction: On Norval Morris's Madness and the Criminal Law, 1985 AM. B. FOUND. RES. J. 385, 397) ("[I]f the public wished to abandon moral blameworthiness (and to substitute factual guilt, the actus reus, as an underpinning for criminal liability), then 'the defenders of the insanity defense would be in trouble."')).

313 Jones v. United States, 463 U.S. 354, 369 \& nn.18-19 (1983) ("There simply is no necessary correlation between severity of the offense and length of time necessary for recovery. The length of the acquittee's hypothetical criminal sentence therefore is irrelevant to the purposes of his commitment.").

314527 U.S. 581 (1999).

315 Perlin, ADA Impact on Criminal Defendant Institutionalization, supra note 6, at 194-95.

316 Commentators, as long ago as 1976 , had argued that state policies that mandated the institutionalization of insanity acquittees in maximum security facilities were violative of the "least restrictive alternative doctrine," and that due process mandated that placements of insanity acquittees must be made to "the least drastic setting commensurate with [the defendant's] condition subsequent to his commitment hearing." Id. at 210-11 (quoting, in part, June German \& Anne Singer, Punishing the Not Guilty: Hospitalization of Persons Acquitted by Reason of Insanity, 29 RUTGERS L. REV. 1011,1052 (1976)).

317 PERLIN, THE JURISPRUdENCE OF THE INSANITY DEFENSE, supra note 128 , at 110-11.
} 
tutionalization and community monitoring. ${ }^{318}$

Any sort of involuntary commitment for the purpose of treatment should be therapeutically appropriate, meaning that commitment is only permissible if it will produce clinical benefits for the patient. ${ }^{319}$ Transferring insanity acquittees from psychiatric facilities to prisons serves no clinical purpose for the patient; it is done solely on the basis of a patient's perceived dangerousness. ${ }^{320}$

There are other LRAs that should be utilized instead of transferring patients to prisons. For example, specialized training and increased staffing could alleviate some of the safety issues that purportedly underline the need for transfer to a prison setting. At the very least, the creation of a specialized mental health facility within the prison setting could potentially satisfy due process and equal protection rights. ${ }^{321}$ What is clear according to $\mathrm{TJ}$ principles is that removing patients from a therapeutic setting and instead placing them in a correctional setting must be avoided at all costs.

\section{TJ and Continuity of Care.}

There have been astonishingly few considerations of the relationship between TJ and continuity-of-care issues. ${ }^{322}$ In the most important analysis yet offered, Rebecca Spain Broches has adopted the view that "criminal justice system procedures that disrupt the course of treatment

\footnotetext{
${ }^{318}$ Accord Perlin, Insanity Defense and Incompetency Status Required by CRPD \& TJ, supra note 6 , at 513 ("We must rigorously apply TJ principles to each aspect of the insanity defense. We need to take what we learn from TJ to strip away sanist behavior, pretextual reasoning, and teleological decision-making from the insanity-defense process."); PERLIN, HIDDEN PREJUDICE \& MENTAL DISABILITY, supra note 223, at 299 ("Until rigorous therapeutic jurisprudence analyses are applied, arguments about whether insanity acquittees should have the same rights, fewer rights, or more rights than civil patients in these areas will likely remain unresolved.")

319 Accord generally Bruce J. Winick, Ambiguities in the Legal Meaning and Significance of Mental Illness, 1 PSYCHOL. PUB. POL'Y \& L. 534, 582 (1995) ("Even when the individual suffers from a condition that properly can be considered a mental illness in the narrow sense that I have argued should be required for involuntary hospitalization, commitment should still satisfy the therapeutic appropriateness principle that I suggest is reflected in Foucha and Riggins. Under this principle, commitment would seem permissible only if it will produce clinical benefits for the patient.").

${ }^{320}$ See, e.g., REV. CODE WASH. $\$ 10.77 .091(1)$ (permitting transfer if certain procedural requirements are met and the person "presents an unreasonable safety risk which, based on behavior, clinical history, and facility security is not manageable in a state hospital setting").

${ }^{321}$ Accord Kempner, supra note 34, at 642-45 ("Where a state lacks appropriate secure facilities, placement of dangerous acquittees in a separate wing of a prison facility specifically staffed by the Department of Health for treatment purposes, may not be an excessive 'alternative purpose."'). That is not to say that such facilities are not without potential problems. In Washington v. Harper, 494 U.S. 210 (1990), the Supreme Court sharply limited prisoners' right to refuse treatment in such a facility. See, e.g., Brian Shagan, Washington v. Harper: Forced Medication and Substantive Due Process, 25 CONN. L. REV. 265, 293 (1992) (criticizing the Harper decision as flawed, warning that the standard it established could become negative precedent for involuntary medication of all "dangerous" criminals).

${ }_{322}$ These issues, however, are addressed in some depth in Broches, supra note 200, as well as more recently in Weinstein \& Perlin, Cycle Deprives Continuity of Care, supra note 35, at 481-86.
} 
are contrary to the vision, developed by therapeutic jurisprudence[], that law should further therapeutic ends." 323 She points out that "[w]hen continuity of care is disrupted in an individual's course of treatment, that individual is more likely to relapse or decompensate." 324 Based on her study of inmates with mental illness in New York City jails, Broches concludes that "[p]olicymakers and clinicians should create and preserve continuity of care by implementing an information-sharing system that better communicates treatment history across systems and providers at intake, and by establishing a system of comprehensive treatment teams that work with patients on both sides of the bars."

We agree entirely with Broches and suggest that her findings be the first building block in the creation of new policies that break the cycle of continuity-disruption. We further suggest that, in the words of an important report on the importance of mental health and criminal justice interventions, we acknowledge that "the person, while both having a serious mental illness and entanglements with the justice system, is more than an illness or an offender." ${ }^{326}$ It is also worthwhile to note that, based on principles in the medical profession, "[o]ne of the most important reasons for nonadherence is the failure of the health care professional ('HCP') to instruct the patient adequately about the treatment regimen." 327 Nonadherence can be avoided by health care professionals engaging with their patients by "introduce[ing] themselves, avoid[ing] unexplained jargon, and elicit[ing] patient suggestions and preferences. ${ }^{328}$

If we acknowledge, as Broches advocates us to, that "symptoms of mental illness [are] the manifestations of a health problem, rather than . . byproducts of criminality," ${ }^{329}$ we can begin to apply therapeutic jurisprudence insights to this problem in ways that might, in fact, begin to ameliorate the woeful situation that we face. To do this effectively, we must demand that discharge procedures in place - ones that "largely de-

\footnotetext{
${ }^{323}$ Broches, supra note 265, at 100 (citing Wexler \& Winick, TJ \& Criminal Justice Mental Health Issues, supra note 265, at 225).

324 Id.

325 Id. at 122

326 Matthew Epperson et al., THE NeXT Generation of Behavioral Health and CRIMINAL JUSTICE INTERVENTIONS: IMPROVING OUTCOMES BY IMPROVING INTERVENTIONS 29 (2011),

http://citeseerx.ist.psu.edu/viewdoc/download;jsessionid=5E54BED88872239C0C610902400B41D9 ?doi=10.1.1.727.9810\&rep=rep1\&type $=$ pdf (completed in association with Rutgers Center for Behavioral Health Services and Criminal Justice Research).

327 David B. Wexler, Therapeutic Jurisprudence and the Criminal Courts, 35 WM. \& MARY L. REV. 279, 292 (1993) (citing DONALD MEICHENBAUM \& DENNIS C. TURK, FaCilitating TREATMENT ADHERENCE: A PRACTITIONER's GUIDEBOOK 67 (1987), [hereinafter MEICHENBAUM \& TURK] to note that "[o]ne of the most important reasons for nonadherence is the failure of the health care professional ('HCP') to instruct the patient adequately about the treatment regimen").

${ }^{328}$ Id. (citing MEICHENBAUM \& TURK, supra note 327 , at 81 , to note that "HCPs are advised, by contrast, to introduce themselves, avoid unexplained jargon, and elicit patient suggestions and preferences").

${ }^{329}$ See Broches, supra note 200, at 100 ("Policymakers must do more to treat the symptoms of mental illness as the manifestations of a health problem, rather than as byproducts of criminality.").
} 
termine whether any mental health gains made during incarceration will translate into the outside world" ${ }^{330}$ - actually serve the individual so as to "provide a strong foundation for a successful reentry process." values of continuity of care-how it "improve[s] post-release engagement with mental health services, ${ }^{, 332}$ how transition planning facilitates such continuity of care, ${ }^{333}$ and how a correctional system that adopts such transitional services can "direct[ly] effect" post-release physical and mental health ${ }^{334}$-are totally consonant with therapeutic jurisprudence values.

\section{B. TJ and "Positive Blur" Issues.}

\section{TJ and Mental Health Courts.}

There is a robust connection between mental health courts and therapeutic jurisprudence. ${ }^{335}$ Indeed, problem-solving courts are all theoretically premised on therapeutic jurisprudence. ${ }^{336}$ By way of example of the

\footnotetext{
330 Id. at 111 .

${ }^{331}$ Id.
}

${ }^{332}$ See Brian McKenna, Jeremy Skipworth \& Krishna Pillai, Mental Health Care and Treatment in Prisons: A New Paradigm to Support Best Practice, 16 WORLD PSYCHIATRY 3, 3 (2017) ("The evidence for the success of [release planning] endeavours is gaining momentum, with indications of the positive impact of systematic prison in-reach models of care on detecting those requiring assistance and improving post-release engagement with mental health services.").

333 See generally Jacques Baillargeon, Steven K. Hoge \& Joseph V. Penn, Addressing the Challenge of Community Reentry among Released Inmates with Serious Mental Illness, 46 AM. J. COMMUNITY PSYCHOL. 361 (2010) (examining "the various challenges confronting mentally ill individuals upon their release from prison and describe some of the more promising models for facilitating a successful transition to the community").

334 Freudenberg, supra note 192, at 214 (noting in the abstract that "[c]orrectional systems can have a direct effect on the health of urban populations by offering health care and health promotion in jails and prisons, by linking inmates to community services after release, and by assisting in the process of community reintegration").

${ }^{335}$ See generally, e.g., Michael Perlin, "There Are No Trials Inside the Gates of Eden": Mental Health Courts, the Convention on the Rights of Persons with Disabilities, Dignity, and the Promise of Therapeutic Jurisprudence, in COERCIVE CARE: RIGHTS, LAW AND POLICY 193 (Bernadette McSherry \& Ian Freckelton eds., 2013); see also, e.g., Thomas E. Schacht, Prevention Strategies to Protect Professionals and Families Involved in High-Conflict Divorce, 22 U. ARK. LITTLE ROCK L. REV. 565, 582 (2000) (noting, under a section header advocating readers to "Embrace Therapeutic Jurisprudence," that "[o]ne mechanism for accomplishing [consolidation of judicial cases belonging to different individuals in a divorce proceeding such as stressed children and the parents] would be to create truly specialized courts, analogous to the mental health courts that have been established in Broward County, Florida and King County, Washington."). For an analysis of the use of therapeutic jurisprudence in veterans' courts, see Perlin, Veterans' Courts as Problem-Solving Courts, supra note 42 . On such courts in general, see Baldwin, supra note 39.

${ }^{336}$ See generally Castellano, Judges in MHCs, supra note 225, Castellano, Case Managers in MHCs, supra note 234, and CASTELlANO, ROLE OF NONPROFIT CASEWORKERS IN PRETRIAL RELEASE, supra note 324. But see Johnston \& Flynn, supra note 44, at 693 (criticizing sharply the non-therapeutic jurisprudence operations of mental health courts in Erie County, Pennsylvania). 
robust connection, one study has found that "increased levels of initial perceived voluntariness and procedural justice, and MHC knowledge, led to decreased rates of new arrests, prison, $\mathrm{MHC}$ bench warrants, and increased court compliance, which, in turn, led to a higher likelihood of MHC graduation." 337 Of course, given the direct linkage of mental health courts with the criminal justice system, the potential power for coercion is certainly, at the least, a dormant issue. ${ }^{338}$

However, the early reports on these courts-specifically the one in Broward County ${ }^{339}$-suggest that the blurring problems seen in involuntary outpatient commitment and SVPAs are, by and large, not present where $\mathrm{TJ}$ is actually and authentically implemented and that, in these courts, $\mathrm{TJ}$ will be the best tool to expose the pretextuality that has so dominated the mental disability law system. ${ }^{340}$

\section{TJ and the $A D A$.}

As one of the authors previously noted, "at first blush, the ADA is as therapeutic a law as one can imagine (as it focuses on ability, not disability, and sets out a blueprint for social, political and cultural change)."341 Title I of the ADA "arguably has great therapeutic value" in that it allows for persons with mental disability to more easily access

\footnotetext{
337 Redlich \& Han, supra note 43, at 116 (noting that this "significant indirect path remained" "[a]lthough [a] direct effect became nonsignificant when mediator variables were included"); see also Ferrazzi \& Krupa, supra note 240 (arguing that greater consideration of mental health rehabilitation will improve the theoretical validity of therapeutic jurisprudence in this context).

338 But see, e.g., Stacey M. Faraci, Slip Slidin' Away? Will Our Nation's Mental Health Court Experiment Diminish the Rights of the Mentally Ill?, 22 QUINNIPIAC L. REV. 81 1, 853 (2004) (arguing that mental health court defendants "endure much more liberty restrictions and privacy intrusions" and that labeling the "sentence 'treatment,' rather than 'punishment," allows the Court to exert more coercion over the participant than would otherwise be available); see generally Johnston \& Flynn, supra note 44 (reporting on negative mental health court data from one Pennsylvania county).

339 Perlin, Using TJ to Remediate Criminalization, supra note 207, at 368 (discussing findings regarding Broward County Mental Health Court in Poythress et al., supra note 240, at 529-30, noting based on these findings that "defendants who appear in that court report a higher score on a "dignity' scale (and a lower score on a 'perceived coercion' scale) than any group of criminal defendants who have ever been studied).

${ }^{340}$ See Perlin, Difference of $M H C s$, supra note 42, at 949-50 (noting that "[i]t is essential that [mental health courts] be free of the 'pretextual dishonesty' that is so often the hallmark of judicial proceedings in cases of individuals with mental disabilities," and citing, inter alia, Ian Freckelton, Mental Health Review Tribunal Decision-Making: A Therapeutic Jurisprudence Lens, 10 PSYCHIATRY PSYCHOL. \& L. 44, 59 (2003), which therein notes that "[a]part from the fact that condescension ought not to be the hallmark of any proceeding, particularly when it involves the entitlements of someone who has lost important aspects of their freedom and autonomy, it is likely to reduce the capacity of the detainee to supply necessary information to the decision-making body - an empowered witness is likely to be a more articulate and confident communicator, as well as later a more satisfied consumer of the review tribunal process. Preferably, the patient should be given the option as to how they are addressed").

${ }^{341}$ Michael L. Perlin, The ADA and Persons with Mental Disabilities: Can Sanist Attitudes Be Undone?, 8 J.L. \& HEALTH 15, 44-45 (1994).
} 
employment and be free from discrimination at the workplace. ${ }^{342}$ Further, Title II of the ADA prohibits unjustified isolation for persons with mental disabilities which ensures that persons with mental disability are able to fully participate in society. ${ }^{343}$ The actual implementation of the ADA to the areas of insanity acquittees, parolees, prisoners, patients, and arrestees could, potentially, be transformative and combat sanism, expose pretexuality, and provide the building blocks of TJ. ${ }^{344}$

The application of the ADA in Olmstead ${ }^{345}$ demonstrates that involuntary civil commitment hearings can, as one of the authors previously noted, be "transformed in appropriate cases into vehicles that genuinely and thoughtfully consider restrictivity of confinement and availability of community placements and treatment" to "provide authentic due process," which is when "mental disability law [is] at its most therapeutic. ${ }^{346}$ However, it is incumbent upon counsel to take the lead in order to reverse the anti-therapeutic effect of involuntarily confining persons with mental disabilities. ${ }^{347}$ The positive blurring of the ADA can enhance TJ principles while ensuring that persons with mental disabilities are afforded due process and equal protection rights.

\section{CONCLUSION}

Notwithstanding the fact that patients' rights lawyers have "historically ... imposed a strict orthodoxy of analysis geared to separating out 'criminal' mental health law from "civil' mental health law,", 348 the past

\footnotetext{
342 Accord Deborah A. Dorfman, Effectively Implementing Title I of the Americans with Disabilities Act for Mentally Disabled Persons: A Therapeutic Jurisprudence Analysis, 8 J.L. HEALTH 105, 114 (1994) (noting that "[a]s a law, Title I of the ADA arguably has great therapeutic value" and citing Americans with Disabilities Act (ADA), 42 U.S.C. $\S 12112$ to note that "[o]ne of the most therapeutic attributes of this law is that it encourages the mentally disabled to seek employment and makes it more difficult for employers to refuse to hire an individual because of a mental disability").

${ }^{343}$ Olmstead v. L.C. ex rel. Zimring, 527 U.S. 581, 597(1999) (holding that "[u]njustified isolation . . . is properly regarded as discrimination based on disability" and citing 42 U.S.C. $\$ 12131$ ).

${ }_{344}$ Accord Perlin, Will Olmstead Resuscitate the LRA, supra note 13, at 1004 ("I conclude that Olmstead has tremendous (albeit still-untapped) potential for combating both sanism and pretextuality in the involuntary civil commitment/periodic review process, and that its expanded role/use-as a tool to enforce the least restrictive alternative mandate-is clearly therapeutic. I will conclude with some recommendations and some thoughts as to how this may potentially influence other aspects of institutional mental disability law.").

345 Olmstead v. L.C. ex rel. Zimring, 527 U.S. 581,597 (1999).

346 Perlin, Will Olmstead Resuscitate the LRA, supra note 13, at 1049.

${ }_{347}$ Accord generally id. at 1049 ("[The provision of due process] will not happen, of course, unless counsel takes the lead. The inadequacy of lawyering in the involuntary civil commitment process is well-known; its perpetuation - to which courts, legislatures and bar associations have been willfully blind for years - has been sanist and pretextual. Unless there is a profound shift in the attitudes of counsel (and in the attitudes of judges who assign counsel), Olmstead is in danger of being little more than another 'paper victory' for persons with mental disabilities."); Perlin, Difference of $M H C s$, supra note 42 , at $940-42$ (noting the lack of adequacy of counsel in many involuntary civil commitment cases).

348 Perlin, ADA Impact on Criminal Defendant Institutionalization, supra note 6, at 195 (citing Perlin, Rights of Mentally Disabled in the Criminal Process, supra note 6, at 1891, and noting "the
} 
two decades have seen important blurs between these two streams of the law develop, in ways that call into question the rationales of those early cases that were the foundational blocks of constitutional mental disability law. ${ }^{349}$ It is critically important that we acknowledge these blurs and that we assess their potential impact on all of this area of law and policy.

By way of examples, the sources of AOT laws and SVP laws are very different. AOT laws seek to provide mandatory treatment for individuals who may not meet statutory involuntary civil commitment standards. SVP laws seek to use involuntary civil commitment as a tool to lengthen the institutionalizations of certain violent sex offenders. As we have discussed extensively, we believe that both blur the boundaries between criminal and civil mental disability law in ways that are inappropriate, ultimately counterproductive, and contrary to the principles of TJ.

Similarly, transferring insanity acquittees from psychiatric hospitals to prisons settings also blurs the boundaries between criminal and civil mental disability law in a way that has important negative impacts on the acquittees. Not only is this in direct contravention of TJ, but it also undermines continuity of care as it relates to one important sub-population of persons institutionalized because of mental disability. Without such continuity of care, purportedly therapeutic intervention will have little impact. Paradoxically, continuity of care-an important principle that needs far more attention than has been heretofore provided-can benefit from positive blurring between civil and criminal mental disability law in that it can optimally prevent the shuttling of persons between hospitals and jails and thus lead to less disruption in treatment, resulting in more positive therapeutic outcomes.

Similarly, if we create more mental health courts that genuinely follow TJ principles, and if we expand the application of the ADA in a TJ context to the populations in questions, we would best be able to ameliorate the negative blurring of criminal and civil mental disability law in the form of laws governing AOT, SVP, and insanity-acquittee transfers.

The relationship between civil and criminal mental disability law has always been a chaotic one. ${ }^{350}$ But it is only in recent years that the sort of blurring discussed here has been employed in ways that are overtly pretextual and sanist, that increase the already "irrational and incoherent" state of mental disability law, ${ }^{351}$ and that, from a TJ perspective, are

patients' rights bar and the mental disability advocates who historically have imposed a strict orthodoxy of analysis geared to separating out 'criminal' mental health law from 'civil' mental health law").

349 See supra note 225 and accompanying text.

350 The chaos in insanity defense law in particular was pointed out nearly 100 years ago. See Christopher Slobogin, An End to Insanity: Recasting the Role of Mental Disability in Criminal Cases, 86 Va. L. Rev. 1199, 1199 n.1 (2000) (quoting S. SHELDON GLUECK, MENTAL DiSORDER AND THE CRIMINAL LAW: A STUDY IN MEDICO-SOCIOLOGICAL JURISPRUDENCE 187-88 (1925) as stating that "[n]ot a modern text or compilation begins the discussion of the subject of insanity and its relation to the criminal law without a doleful reference to the chaos in this field.").

351 See, e.g., Perlin, Sanism \& Pretextuality, supra note 11, at 3-5, 28-36 (concluding that mental 
profoundly anti-therapeutic. And this has serious implications for all of us-whether we are lawyers, judges, or mental health professionals, academics, researchers, or clinicians. If we ignore this problem, then the shame and humiliation that persons with mental disability face ${ }^{352}$ is likely only to intensify. Instead, we must embrace the aspects of mental disability law that result in positive blurs, and we must also assess how this embrace can be extended to other areas of mental disability law to alleviate the negative impact of the blurs that we have discussed in this article.

We chose Bob Dylan's Desolation Row to use in the title because of its depiction of a "cultural jumble" built on "general deviance."353 The blur factors discussed here similarly "jumble" mental disability law, as they confound and conflate different types of social deviance. And this creates another desolation row. In one of the starkest images invoked by the song, Dylan sings: "The only sound that's left after the ambulances go is Cinderella sweeping up on desolation row." ${ }^{, 354}$ We hope that, after the expansion of AOT and SVP laws, our failures to ensure continuity of care, and our imprisoning insanity acquittees found not guilty of the underlying charges, there is more than this that is left to mental disability law.

disability law "is irrational and incoherent, and this irrationality and incoherence disables civil commitment law, institutional treatment law, civil rights law, and criminal procedure law"); see also PERLIN, THE JURISPRUDENCE OF THE INSANITY DEFENSE, supra note 128, at 1 ("Our insanity defense jurisprudence is incoherent.").

352 See generally Perlin \& Weinstein, Law, Shame and Humiliation, supra note 104 (discussing shame related to mental health).

${ }^{353}$ See supra notes $50-57$ and accompanying text.

354 DYLAN, supra note 50. 
